\title{
Biodiversity and ecosystem processes in an experimental island system
}

\author{
Dissertation \\ to obtain the Dr. sc. agr. \\ In the Ph. D. Program for Agricultural Sciences in Göttingen (PAG) \\ At the Faculty of Agricultural Sciences, \\ Georg-August-University Göttingen, Germany
}

\author{
Presented by \\ Hagen Andert \\ Born in Görlitz (Germany)
}

Göttingen, September 2017 


\section{7}

1. Referentin/Referent: Prof. Dr. Teja Tscharntke

2. Korreferentin/Korreferent: Prof. Dr. Christoph Scherber

Tag der mündlichen Prüfung: 15. November 2017 
To Darja, Arnt and Lea, and those, who always keep the bright lantern burning in dark nights. 
Alles Wissen und alle Vermehrung unseres Wissens endet nicht mit einem Schlusspunkt, sondern mit Fragezeichen.

[All knowledge and all multiplication of our knowledge does not end with a final point, but with question marks.]

Hermann Hesse (1877-1962) 


\section{Contents}

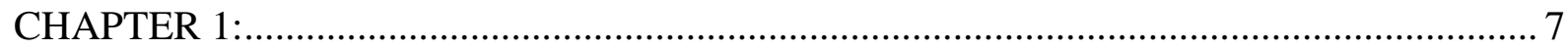

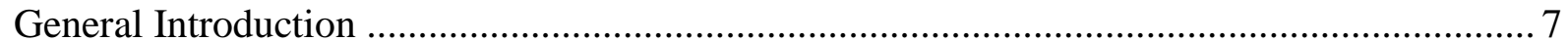

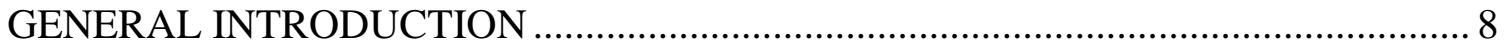

STUDY REGION AND EXPERIMENTAL ISLAND SYSTEM.................................... 9

The German barrier island Spiekeroog ………………............................................. 9

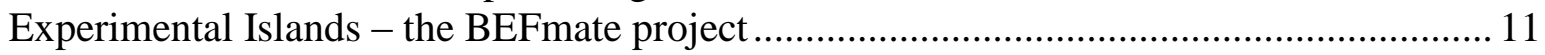

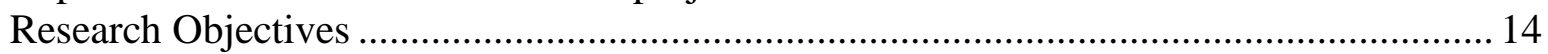

Chapter Outline ………………………………………………………………... 14

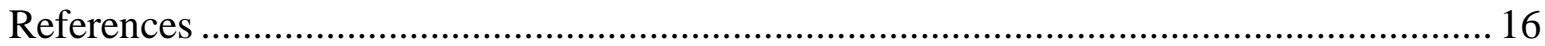

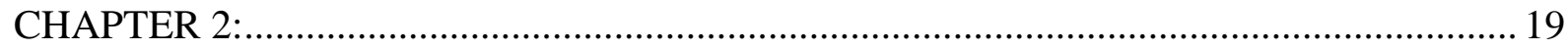

A barrier island perspective on species-area-relationships .................................................. 19

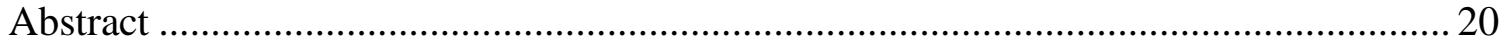

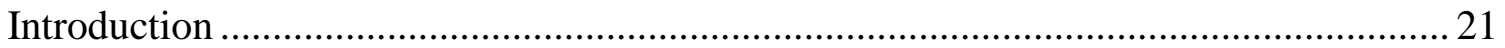

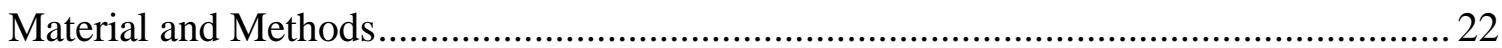

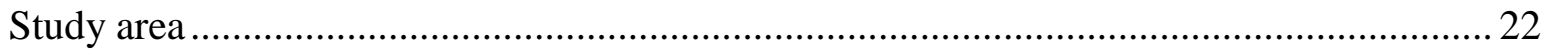

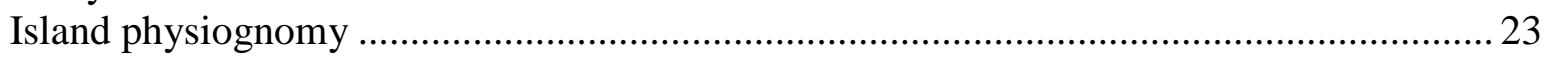

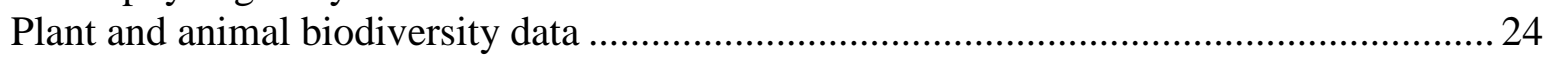

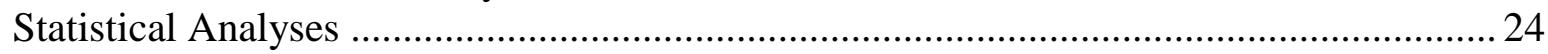

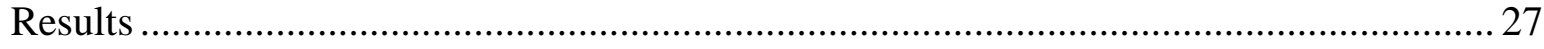

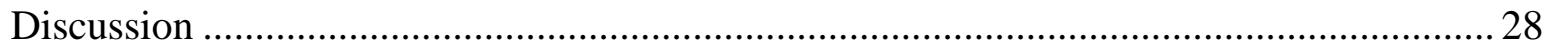

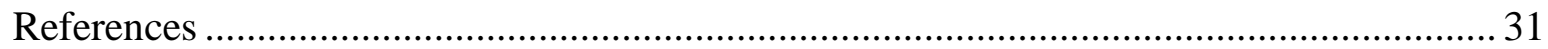

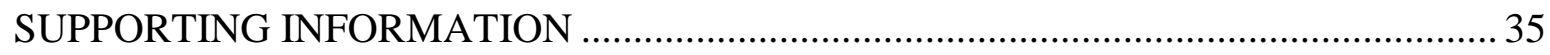

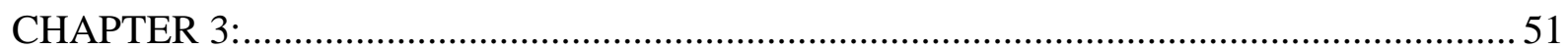

Colonization and taxon shift in an experimental island system ...........................................51

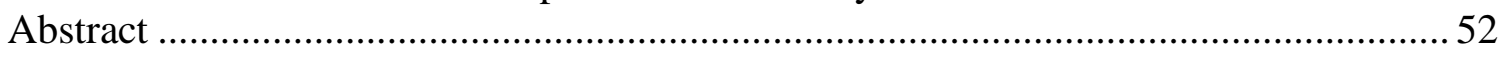

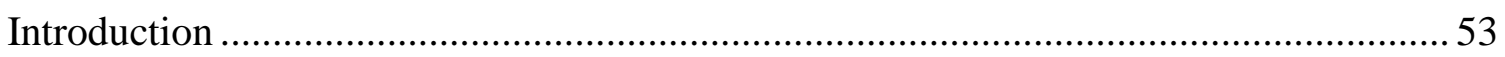

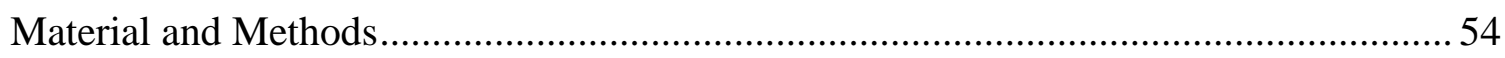

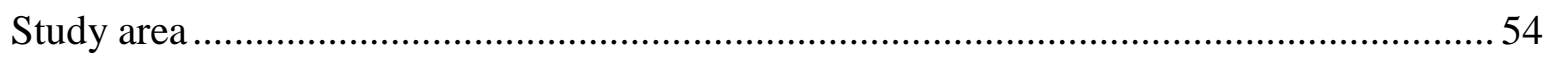

Experimental islands and sampling design .............................................................. 54

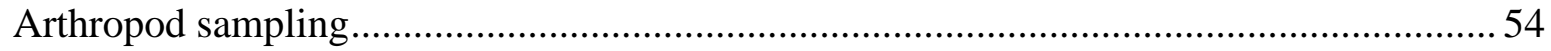

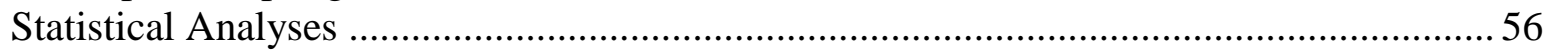

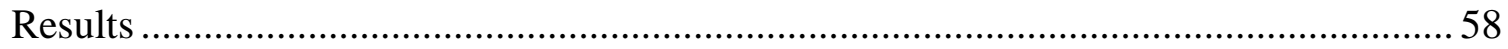

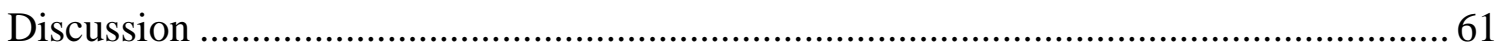

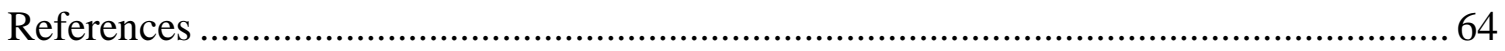

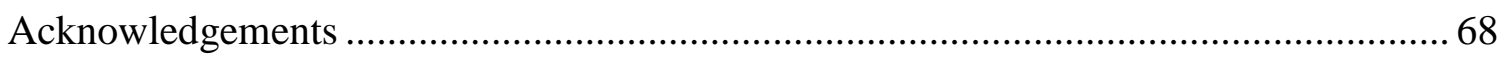

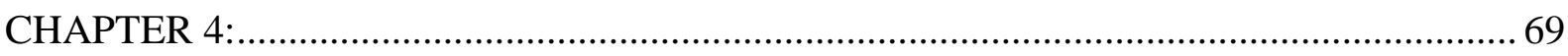

Diversity of decomposing flies and carcass decay in experimental salt-marsh islands of the

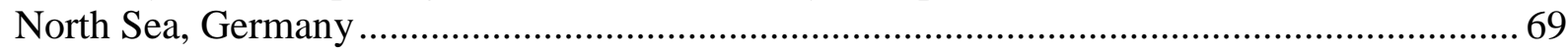

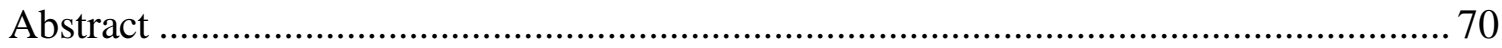

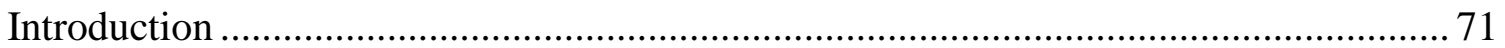

Material and Methods.........................................................................................

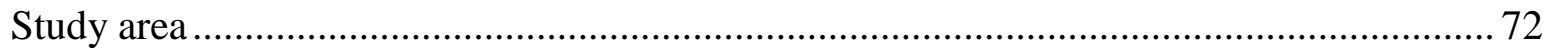

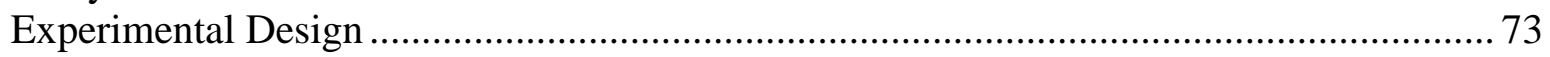

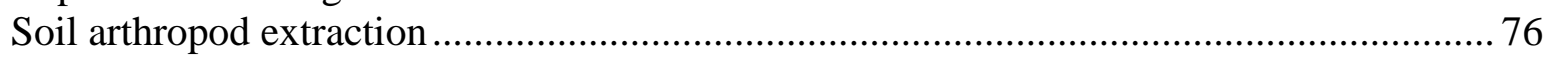

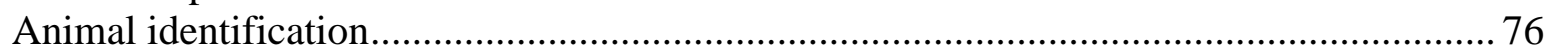




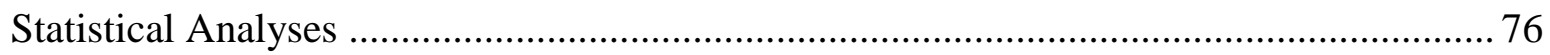

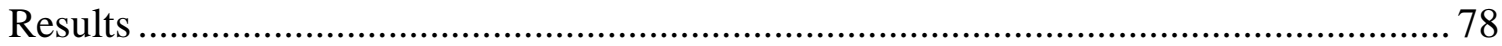

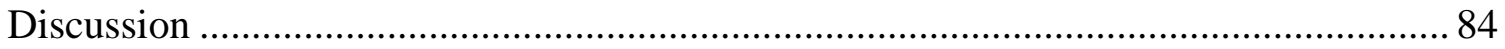

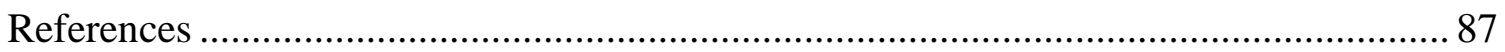

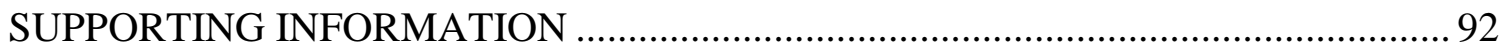

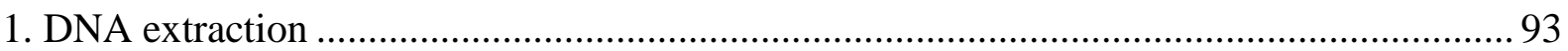

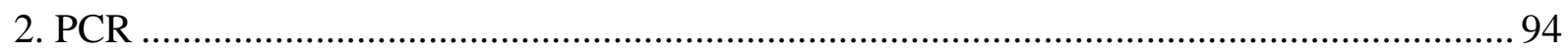

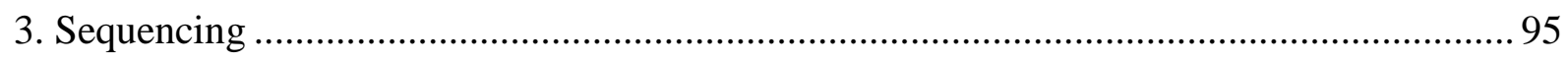

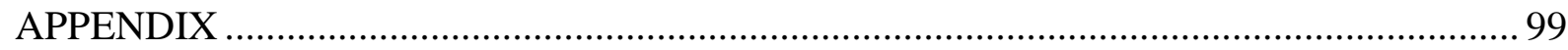

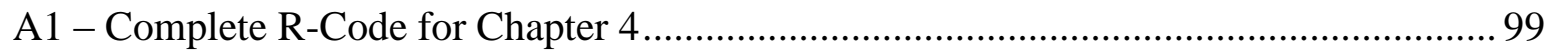

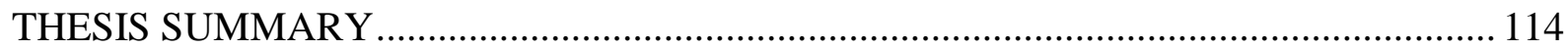

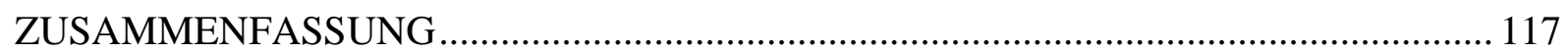

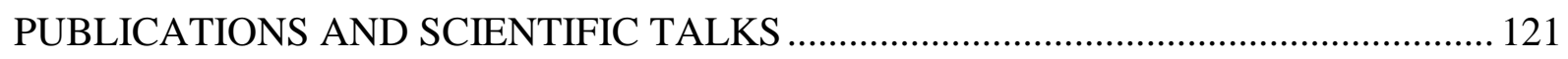

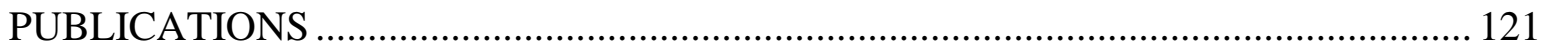

CONFERENCE CONTRIBUTIONS AND SCIENTIFIC TALKS ................................. 121

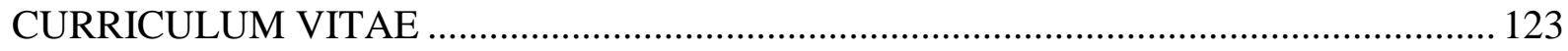

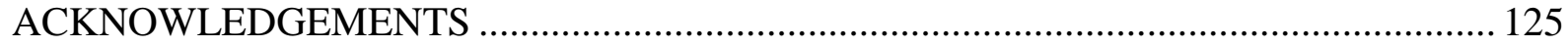

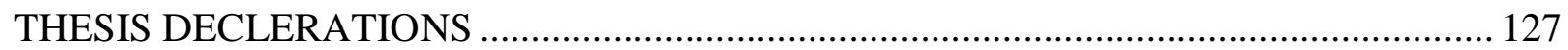

Decleration of the author's own contribution to manuscripts with multiple authors ......... 127

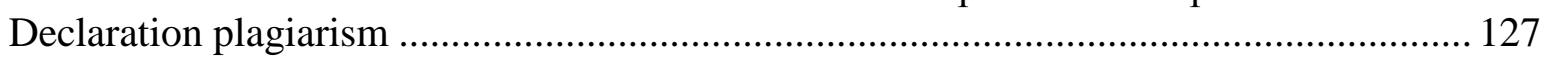


CHAPTER 1:

\section{General Introduction}

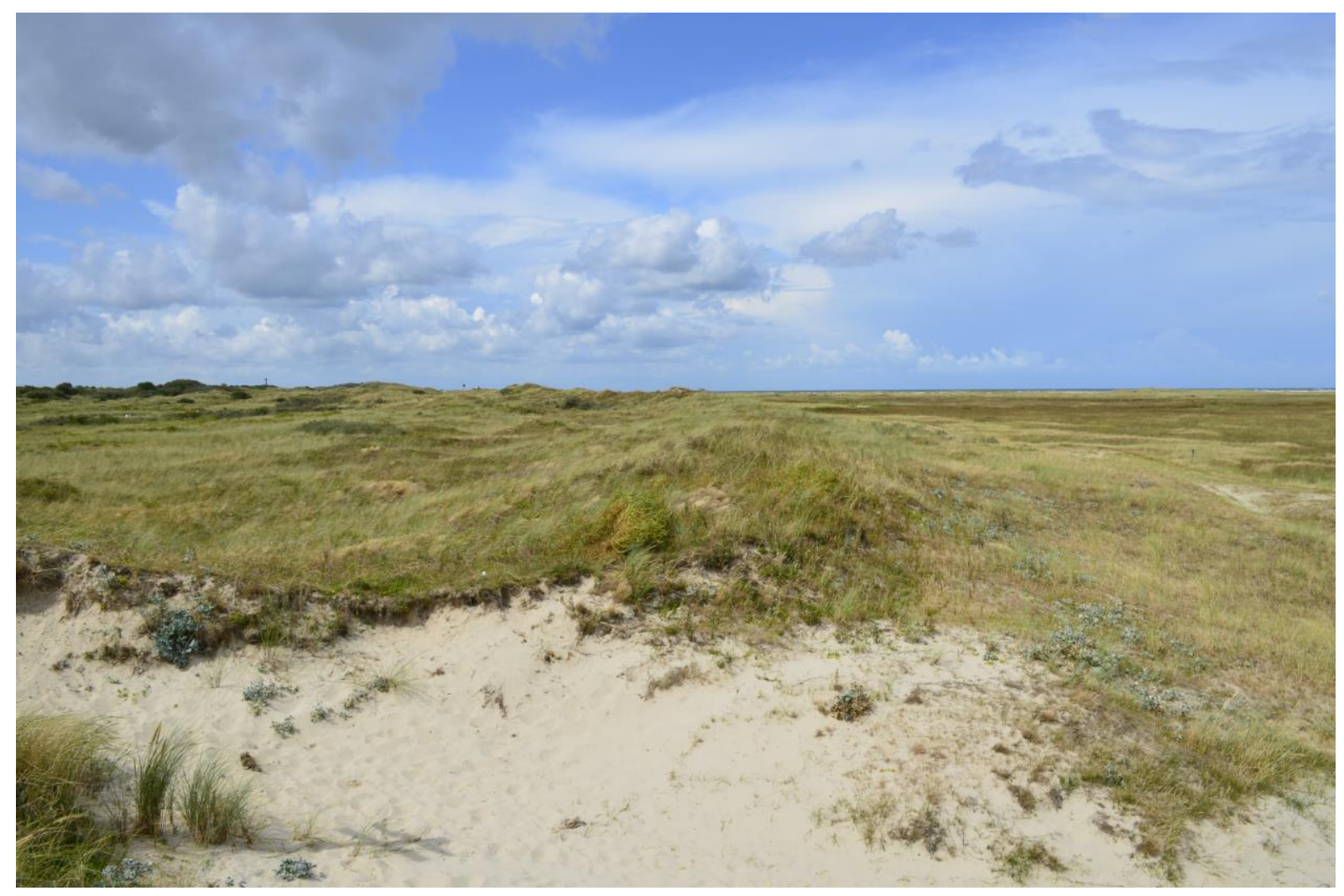




\section{GENERAL INTRODUCTION}

Island systems have become one of the most important model systems in ecology for the last decades (Losos and Ricklefs, 2010, MacArthur and Wilson, 1967). Their discrete and isolated nature make islands a useful tool for ecological and evolutionary studies (Whittaker and Fernández-Palacios, 2007) and therefore act as a model system for isolated habitat fragments in different contexts (Losos and Ricklefs 2010, Hanski et al. 2010, Kruess and Tscharntke, 1994). The original theory of island biogeography (TIB), established by MacArthur and Wilson in 1967, describes island colonization as a dynamic equilibrium between the opposing processes of immigration and extinction of species (Weigelt and Kreft, 2013). Small or isolated islands are less colonized by immigrants than larger or connected ones. Therefore smaller islands display lower species richness. Larger islands act as a refuge of a larger variety of habitat niches (Lomolino 2000, MacArthur and Wilson, 1967). As isolation has been assumed as one of the largest driving factors influencing species richness on islands, later studies demonstrate the importance of evolutionary processes such as volcanic activity or island submergance from erosion at large time scales on oceanic islands (Whittaker et al. 2008). Depending on island type and the scale effect of different island studies, discrete results both negative and positive for different levels of island isolation to neighboring islands or mainland cores have been observed in former studies (Cardoso et al 2010, Bellemain and Ricklefs 2008, Price 2004). Additionally, area, island elevation, energy and numerous other factors appear to control the variation in their form (Whittaker 1998) of species-area-relationships (Whittaker et al 2001). Whittaker and colleagues suggested in 2001 that focusing on area only will obliterate the importance of other environmental cofactors varying differently with area (Whittaker et al 2001). Ten years after, the theory of island biogeography has been enlightened by the trophic theory of island biogeography (TTIB, Gravel et al. 2011). In this approach, not only anatomical or ecological traits like body size or dispersal ability completed TIB - furthermore, trophic identity and breadth determine species richness distributions on islands (Gravel et al. 2011, Jacquet et al. 2017). TTIBs main conclusion is that smaller islands are accessed and colonized by predators which have a broader trophic spectrum compared with predators on larger islands.

Most of the studies in the field of island biogeography have been conducted on oceanic islands or archipelagos. Beside this island type, three other island categories occur in the 
recent literature (Whittaker 1998): continental shelf islands, habitat islands and nonmarine islands.

In particular, barrier islands, which do not fall under named island categories occupy a special ecological niche in island systems. They are built by offshore and shore-parallel unconsolidated sediment accumulation processes only (Gillespie and Clague 2009). Barrier islands can be categorized after certain development specifications (Hoyt 1967). As they are controlled by the interaction of waves and tides, tide magnitude is one of the most important factors for island classification. You can find microtidal, mesotidal and macrotidal barrier islands. For this thesis, mesotidal barrier islands are most important as they are influenced by both waves and tides (by comparison, microtidal islands are influenced by waves and macrotidal islands by tidal change only, Gillespie and Clague 2009). Mesotidal shorelines are characterized as 'stunted, usually less as $16 \mathrm{~km}$ in length' (ibidem). Related barrier islands usually show a drumstick-like island shape classified after Stephen (1981).

The offshore East Frisian Islands (Germany) are influenced by mixed energy coast events leading to different island forms (Fitzgerald et al 1984). The plan form of the East Frisain Islands is explained by so called 'inlet sedimentation bypassing' processes resulting in a persistent eastward island growth (ibidem). The island chain is located on a high wave energy shoreline with a high tide range, average wave-height of $1.0 \mathrm{~m}$ and a spring tidal range between $2.7 \mathrm{~m}$ and $2.9 \mathrm{~m}$. Island inlets are delivered by a minimum of $2.7 \times 10^{3} \mathrm{~m}^{3}$ of sand each year (Fitzgerald et al 1984). This sediment is then transformed by water and wind, which results in sand accumulation, formation of sand ripples and after falling dry, dune formation (Niedringhaus et al. 2008). Initial colonization by Ammophila arenaria leads to sediment stabilization and therefore initial salt marsh development (Petersen and Pott 2005). The impact of these unique island sedimentation processes is reported in chapter 2, whereas chapter 3 is based on an experimental island approach, when hypotidal sediment belts rise above mean tidal water level.

\section{STUDY REGION AND EXPERIMENTAL ISLAND SYSTEM}

\section{The German barrier island Spiekeroog}

The study system of this thesis is based on the fourth largest East Frisian Island Spiekeroog in the North of Germany (Lower Saxony, Figure 1). This island belongs to the 
UNESCO World Heritage Site 'Lower Saxon Wadden Sea National Park' (Germany, $\left.53^{\circ} 45^{\prime} 31^{\prime \prime} \mathrm{N}, 7^{\circ} 43^{\prime} 30^{\prime \prime} \mathrm{E}\right)$. Floristically, Spiekeroog has the best structured dunescapes (Pott 1995). Additionally, together with the more eastern island Wangerooge, Spiekeroog is the fourth most distant island to the mainland. Spiekeroog is $18.5 \mathrm{~km}^{2}$ large and expands by $10 \mathrm{~km}$ in length and $2 \mathrm{~km}$ in width (Niedringhaus et al. 2008). Its main core is a semicircular grey dune area expanding from the northern to the eastern part over $1 \mathrm{~km}$ and from west to south by only $100 \mathrm{~m}$. In the $17^{\text {th }}$ and $18^{\text {th }}$ century, this old succession centre of Spiekeroog was fused with the neighbouring islands Luetje Oog and Oldeoog. This led to eastwards oriented island growth. In the $19^{\text {th }}$ century, the western part of Spiekeroog was dyked (Niedringhaus et al. 2008). Therefore, island growth is remains east-oriented only. Compared to other East Frisian Islands, Spiekeroog has the oldest and most undisturbed salt marsh areas (Petersen and Pott 2005) in its south-eastern area.

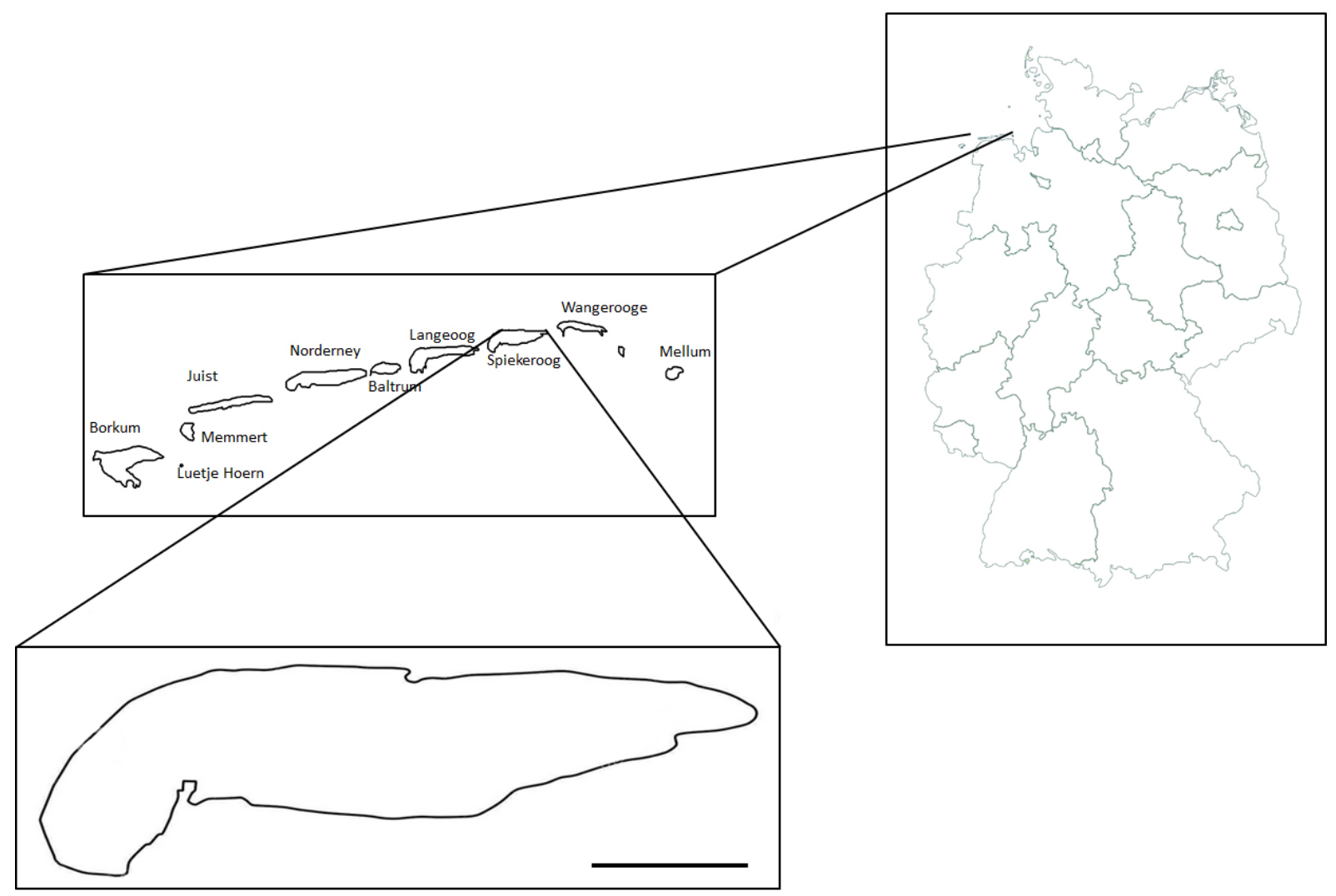

Figure 1 Location of the research are. The East Frisian Islands are located in the Northern Sea area of the state Lower Saxony, Germany. They form a barrier island chain (from West to East: Borkum, Luethe Hoern, Memmert, Juist, Norderney, Baltrum, Langeoog, Spiekeroog, Wangerooge, Minsener Oog (not object of our studies!) and Mellum. Spiekeroog is one of the eastern East Frisian islands with an area of around $18 \mathrm{~km}^{2}(2008$, scale equals $3 \mathrm{~km})$. 
Salt marsh areas can be distinguished into three habitat zones: the marine influenced pioneer zone with an annual tidal change on average over an altitude of $1 \mathrm{~m}$. Halophilic plants like Salicornia europaea, S. stricta, Suaeda maritima and the invasive plant species Spartina anglica dominate the vegetation. Regularly, the soil is clayey with a lot of open areas and open water spaces. Lower Salt marshes are more terrestrially influenced with an average altitude of $1.5 \mathrm{~m}$ and flooding events during spring tide only. Lower salt marshes can be explained as an intermediate zone between the marine pioneer zone and the terrestrial upper salt marshes. Therefore, they are colonized by both marine and terrestrial herbal and herbaceous plants like Artemisia maritima, Aster tripolium, Attriplex portulacoides, Limonium vulgare, Puccinellia maritima, Salicornia stricta and Suaeda maritima. Usually, the most colourful habitat zone in May and June is the upper salt marsh with fields of flowering Armeria maritima and Limonium vulgare. In the location where our project took place, the upper salt marsh was dominated by Elymus athericus only. This really special dominance of wild rye is a result of forgone grazing management (Petersen and Pott 2005). The upper salt marsh has an average altitude of $2.5 \mathrm{~m}$ and is therefore only flooded during storm tide events. Its soil is mostly of sandy structure.

Our experiment took place in these habitat zones for the control and salt marsh control plots.

\section{Experimental Islands - the BEFmate project}

Within the collaborative research project 'Biodiversity-Ecosystem Functioning across marine and terrestrial ecosystems' (BEFmate) by the Carl von Ossietzky University of Oldenburg and the Georg August University Göttingen 12 artificial islands have been built on the backside of Spiekeroog island in autumn 2014. The following description is based on the publication of Balke and colleagues (2017): Half of the islands are bare to research on natural colonization processes, the other six ones are planted with lower salt marsh vegetation sods from Spiekeroog island (Figure 1). Each island consists of twelve $5 \mathrm{~mm}$ thick galvanized steel baskets with $1 \mathrm{~m}^{2}$ base each. Four baskets form one habitat zone (pioneer zone, lower salt marsh and upper salt marsh) in different heights. Each basket is lined with robust non-woven fabric for hydraulic engineering to hold filled wadden sediment back. Three habitat heights are simulated by three different basket eights: $70 \mathrm{~cm}$ baskets with $60 \mathrm{~cm}$ of sediment height for pioneer zone baskets, 
$100 \mathrm{~cm}$ ones with $90 \mathrm{~cm}$ of sediment for lower salt marsh plots and $130 \mathrm{~cm}$ baskets with $120 \mathrm{~cm}$ of sediment height for upper salt marsh baskets. Additionally, ground water levels are controlled by basket inlaying PE film holding back water in the sediment.

Each island is based on a mat made of non-woven fabric for hydraulic engineering and a reinforcement mat. Finally, this foundation is anchored with ground anchors by the mark 'Duckbill'.

Experimental islands are arranged on a counter line of $80 \mathrm{~cm}$ standard elevation zero on a distance of $700 \mathrm{~m}$ in northwestern to southeastern direction. Every island is separated from its neighboring island within $55 \mathrm{~m}$ and in 500m distance to Spiekeroog island.

To control and compare island and experiment specific factors, experimental island conditions have to be reflected in the control areas as well. As a result, differences between experimental islands and control plots can only be explained by higher hydrodynamics around experimental islands and the distance of dispersal (both animal and seeds). For this purpose, non-planted and planted plots have been built in the experimental island design in the same number and size within the naturally occurring salt marsh habitat zones. For unplanted salt marsh plots, $4 \mathrm{~m}^{2}$ of vegetation have been dug out spade deeply for each plot and refilled with wadden sediment. Planted zones have been treated similarly and filled with the same lower salt marsh plant sods as they have been transplanted to the experimental islands additionally. 

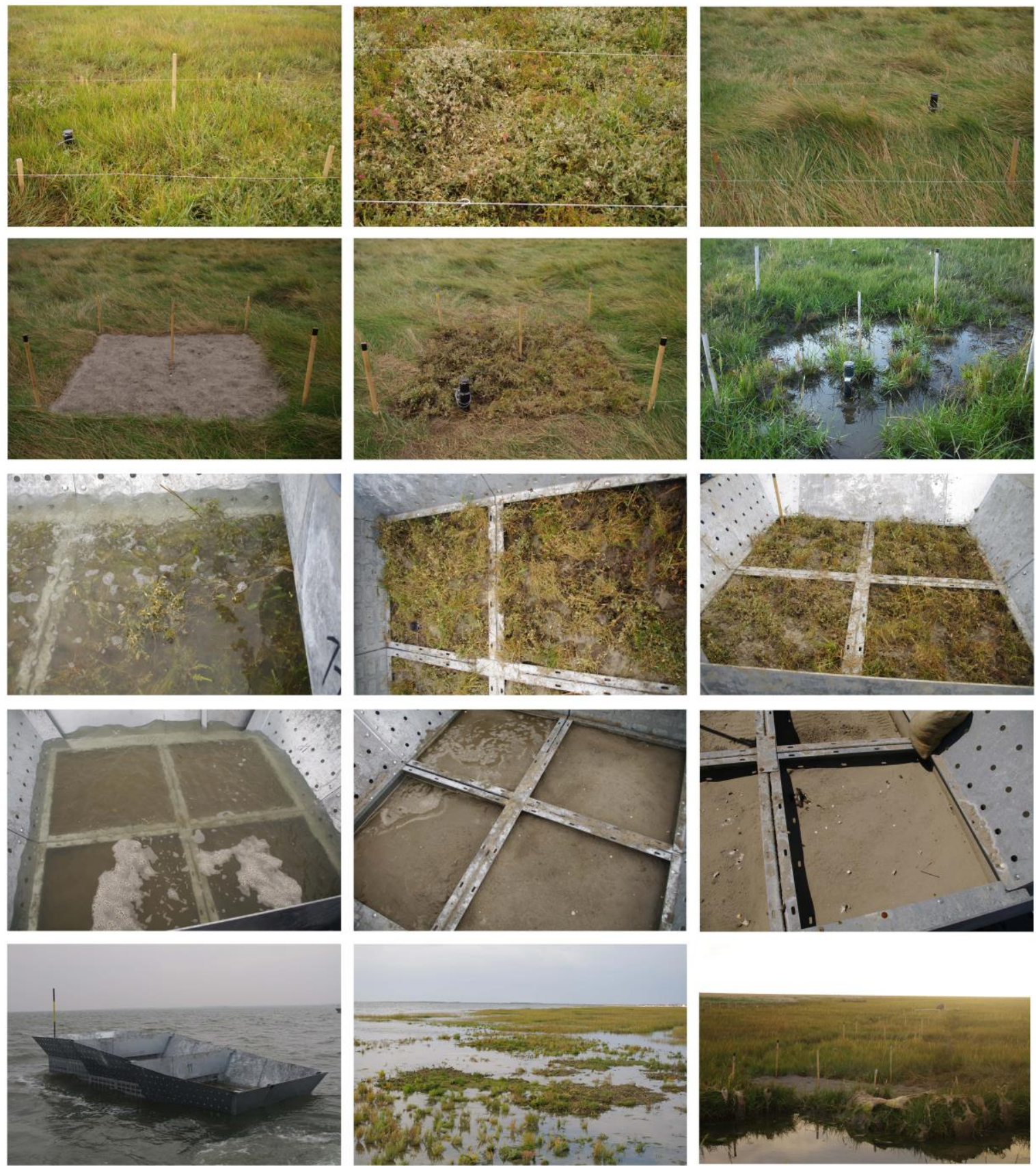

Figure 1 Experimental design of the BEFmate project. The first row display the three naturally occurring habitat zones (from left to right): pioneer zone (Pio) dominated by Spartina anglica, Salicornia spp. and Suaede maritima, lower salt marsh (Low) with dominating Attriplex portulacoides, additionally Artemisia maritima, Aster tripolium, Limonium vulgare, Puccinellia maritima, Salicornia stricta and Suaeda maritima. and upper salt marsh (Upp), which in our plots is only build from Elymus athericus. Second row demonstrates transplanted plots (SMC): wadden sediment filled 'non-planted plots and 'planted plots, the right picture shows a transplanted 'planted plot in the pioneer zone directly after end of high tide. The third row displays planted experimental island plots from pioneer zone level to upper salt marsh level. Ground water is always standing in Pio during low tide, whereas Upp plots are normally (despite storm tide events) unflooded during high tide. In the fourth row, non-planted experimental island plots reflect a 
similar picture. In the last row a non-planted experimental island, Pio habitat and Upp habitat (in the front of the picture a tidal creek partially is photographed) are displayed during daily occurring high tide.

\section{Research Objectives}

Barrier islands symbolize a highly specialized island type which is tremendously underrepresented in island biogeography research. Only a few studies (Charbonneau, Wootton, Wnek, Langley, \& Posner, 2017; Foster et al., 2017) focused general island biogeography patterns onto barrier island habitats and no study thus far has investigated ecosystem functioning patterns of these special offshore sedimentation influenced islands (Whittaker 1998). To fill this research gap, within BEFmate we combine analyses of both biodiversity and ecosystem functioning patterns to get more into the functionality of barrier islands based on the East Frisian Islands.

We therefore address the following three research questions:

(1) Which characteristics of barrier island formation influence species colonization patterns most and are driving community formation on barrier islands?

(2) How is the so called island effect influencing isolated island patches over one season and how is isolation affecting arthropod community composition?

(3) How are habitat zone identity, state of successional development and time influencing the ecosystem function of animal decomposition and which effect for vegetation nutrition emerges from the decomposition process?

\section{Chapter Outline}

\section{CHAPTER 2: A BARRIER ISLAND PERSPECTIVE ON SPECIES-AREA-RELATIONSHIPS}

This chapter focusses on barrier island characteristics both classical and derived from island growth measurements and their impact on taxon occurrence of more than 2,990 species across 36 taxon groups (including vertebrates, invertebrates and land plants) on 10 East Frisian Islands. We tested for relationships between species richness and island area (SAR), for effects of island habitat heterogeneity $(\mathrm{SHH})$ and further island parameters using binomial logistic regression modelling. The positive impact of annual sedimentation rates of barrier islands on rove beetles and flies illustrate the importance of considering ontogenetic island data in the biodiversity analysis of barrier islands. 
Four taxa such as spiders (173 species) and lichens (94 species) were primarily related to area. The heterogeneity of habitat types was a key predictor for the richness of 24 taxa, including bees (101 species), Auchenorrhyncha (131 species), Saltatoria (13 species) and further 21 taxa, whereas richness differences of 6 taxa could not be explained. Overall, richness of taxa differed greatly in their responses, with area (although varying from 0.1 to $38.9 \mathrm{~km}^{2}$ ) playing a minor and island heterogeneity a major role, while barrier island-specific sedimentation rates emerge as a new predictor variable in models explaining species richness (14 out of 31 taxa in total).

\section{CHAPTER 3: COLONIZATION AND TAXON SHIFT IN AN EXPERIMENTAL ISLAND SYSTEM}

This chapter aims at investigating the relationship between island colonizing taxa after fragmentation and isolation of islands.

Due to their high amount of autochthonous species, salt marsh habitats are key targets for conservation and habitat restoration projects in mudflat areas such as the Wadden Sea. Here, we set up an experimental island system consisting of $\mathrm{N}=12$ islands at a distance of c. $500 \mathrm{~m}$ from the barrier island of Spiekeroog (Germany) to study disturbance and colonization dynamics of mobile arthropods. We sampled c. 40,000 arthropods across eight taxa using storm-proof heavy-duty trapping equipment over the course of a full year. All taxa except for leafhoppers (Aphididae, Araneae, Brachycera, Coleoptera, Hymenoptera, Nematocera and Thysanoptera) had lower abundances on artificial islands compared with natural islands, in interaction with time (month of collection) indicating a taxon sorting effect due dispersal limitation in most abundant taxa. Our results suggest that increasing disturbance events such as sea level rise and drought have a negative impact on mobile arthropod populations. In our experiment, total abundance of control taxa was halved on isolated islands. Future sea level rise may cause habitat fragmentation in the North Sea due to higher inundation frequencies after upshifting mean high tide values; this may adversely influence different arthropod communities in salt marsh habitats. Our study provides a real time experimental island approach for observing arthropod community changes. 
This chapter addresses the ecosystem function of animal decomposition in an intertidal experimental island system and its impact on local arthropod diversity.

We performed an animal decomposition experiment within a meta-ecosystem barrier island approach on Spiekeroog, Germany. 264 pieces of cow meat were spread over experimental island and salt marsh habitat plots to observe animal decay in a real-time experiment for two weeks in September, 2015. We caught around 10,000 specimens from 23 invertebrate taxa and analysed the impact of about 2300 decomposition related maggot species in detail. Our results support the trophic theory of island biogeography due to different maggot community patterns. For the first time, we display that species richness of decomposing maggots drives decay related soil nutrition and therefore accessibility of plant available nutrient like carbon, nitrogen and phosphorous. We discuss the importance of these findings and display the importance of animal decomposition with regard to natural conservation measures in highly protected habitats.

\section{References}

Bellemain, E. and Ricklefs, R. (2008). Are islands the end of the colonization road?. Trends Ecol. Evol., 23, 1606-1609

Cardoso, P., Arnedo, M. A., Triantis, K. and Borges, P. A. V. (2010). Drivers of diversity in Macaronesian spiders and the role of species extinctions. J. Biogeogr., 37, 1034-1046.

Charbonneau B. R., Wootton, L. S., Wnek, J. P., Langley, A. and Posner, M.A. (2017). A species effect on storm erosion: Invasive sedge stabilized dunes more than native grass during Hurricane Sandy. J.Appl.Ecol.,54,1385-1394.

Fitzgerald, D. M., Penland, S. and Nummedal, D. (1984). Control of barrier island shape by inlet sediments bypassing: East Frisian Islands, West Germany. Mar.Geol., 60, 355376. 
Foster T. E., Stolen E. D., Hall C. R., Schaub R., Duncan B. W., Hunt D.K. , et al. (2017). Modeling vegetation community responses to sea-level rise on Barrier Island systems: A case study on the Cape Canaveral Barrier Island complex, Florida, USA. PLoS ONE 12(8): e0182605. https://doi.org/10.1371/journal.pone.0182605

Gillespie, R. G. and Clague, D. A. (2009). Encyclopedia of Islands. Berkeley, CA, USA: University of California Press.

Gravel, D., Massol, F., Canard, E., Mouillot, D. and Mouquet, N. (2011). Trophic theory of island biogeography. Ecol. Lett., 14, 1010-1016.

Hanski, I. (2010). Island biogeography and metapopulations. In: The Theory of Island Biogeography Revisited (eds Losos, J. B. and Ricklefs, R. E.). Princeton University Press, Princeton, Nj. 186-213.

Hoyt, J. H. (1967). Barrier island formation. G.Soc.Am.B., 78(9), 1125-1135.

Jacquet, C., Mouillot,D., Kulbicki, M. and Gravel, D. (2017). Extensions of Island Biogeography Theory predict the scaling of functional trait composition with habitat area and isolation. Ecol. Lett., 2010, 135-146.

Kruess, A. and Tscharntke, T. (1994). Habitat fragmentation, species loss, and biological control. Science, 264, 1581-1584.

Lomolino, M.V. (2000). Ecology's most general, yet protean pattern: the species-area relationship. J. Biogeogr., 27, 17-26.

Losos, J. B. and Ricklefs, R.E. (eds) (2010). The Theory of Island Biogeography Revisited. Princeton University Press, Princeton, Nj. 186-213.

MacArthur, R. H. and Wilson, E. O. (1967). The theory of island biogeography. Princeton University Press, New Jearsy. 
Niedringhaus, R., Haeseler, V., Janiesch, P. (eds) (2008). Die Flora und Fauna der Ostfriesischen Inseln - Einführung in das Projekt „Biodiversität im Nationalpark Niedersächsisches Wattenmeer“ - Schr.R. Nationalpark Nieders. Wattenmeer 11.

Petersen, J. and Pott, R. (2005). Ostfriesische Inseln: Landschaft und Vegetation im Wandel, 1st edition, Schlütersche, Hannover.

Price, J. P. (2004). Floristic biogeography of the Hawaiin Islands: influences of area, environment and paleogeography. J. Biogeograph., 31, 487-500.

Stephen, M.E. (1981). Effects of seawall construction on beach and inlet morphology and dynamics at Caxambas Pass, Florida. Ph.D. Diss., University of South Carolina, Columbia, S. C., 196 pp.

Weigelt, P. and Kreft, H. (2013). Quantifying island isolation - insights from global patterns of insular species richness. Ecography, 36, 417-429.

Whittaker, R. J. (1998). Island Biogeography: Ecology, Evolution, and Conservation. Oxford University Press, Oxford.

Whittaker, R. J., Willis, K. J. and Field, R. (2001). Scale and species richness: towards a general, hierarchical theory of species diversity. J. Biogeograph., 28, 453-470.

Whittaker, R. J., Triantis, K. A. and Ladle, R. J. (2008). A general dynamic theory of oceanic island biogeography. J. Biogeograph., 35, 977-994.

Whittaker, R. J. and Fernández-Palacios, J. M. (2007). Island biogeography: ecology, evolution, and conservation, $2^{\text {nd }}$ edn., Oxford University Press, Oxford. 


\section{CHAPTER 2:}

\section{A barrier island perspective on species-area- relationships}

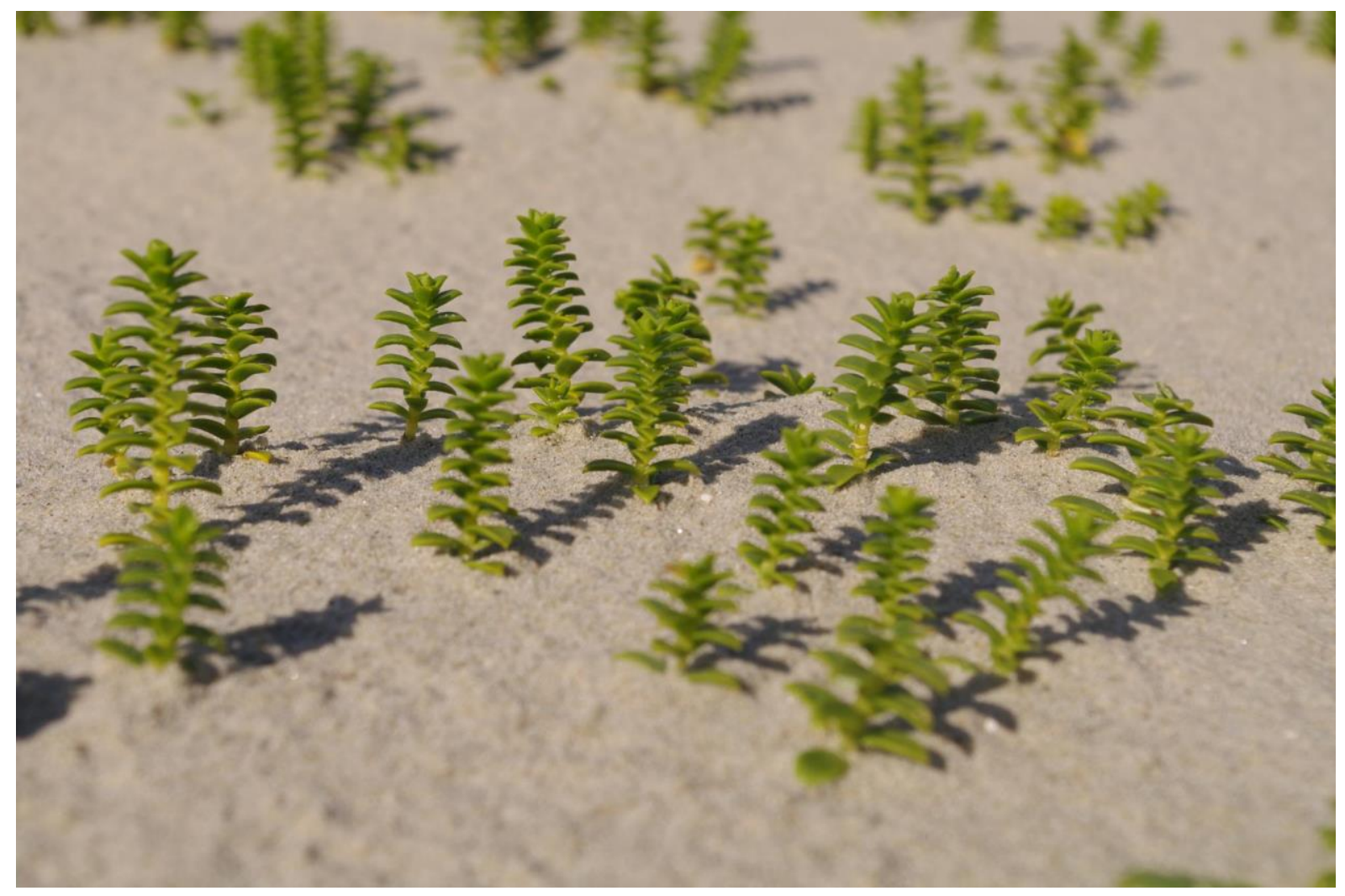

Hagen Andert, Christoph Scherber, Rolf Niedringhaus' Teja Tscharntke

Submitted in the Journal for Biogeography 


\begin{abstract}
Predictions of species richness by island area are a classical cornerstone in ecology, while the specific features of barrier islands have been little appreciated. Many shorelines are occupied by barrier islands, which are shaped by offshore sedimentation processes and annual storm tide events. Hence, the appearance of these islands may vary between years if they are not protected by dykes. Here, we analyzed more than 2,990 species across 36 taxon groups (including vertebrates, invertebrates and land plants) on German barrier islands, the East Frisian Islands. We tested for relationships between species richness and island area (SAR), for effects of island habitat heterogeneity (SHH) and further island parameters using binomial logistic regression modelling. The positive impact of annual sedimentation rates of barrier islands on rove beetles and flies illustrate the importance of considering ontogenetic island data in the biodiversity analysis of barrier islands. Four taxa such as spiders (173 species) and lichens (94 species) were primarily related to area. The heterogeneity of habitat types was a key predictor for the richness of 24 taxa, including bees (101 species), Auchenorrhyncha (131 species), Saltatoria (13 species) and further 21 taxa, whereas richness differences of 6 taxa could not be explained. Overall, richness of taxa differed greatly in their responses, with area (although varying from 0.1 to $38.9 \mathrm{~km}^{2}$ ) playing a minor and island heterogeneity a major role, while barrier island-specific sedimentation rates emerge as a new predictor variable in models explaining species richness (14 out of 31 taxa in total).
\end{abstract}

barrier islands, habitat heterogeneity, invertebrates, island ontogeny, nature conservation, niche hypothesis, plants, sedimentation, species richness of vertebrates 


\section{Introduction}

Analyses of SAR have stimulated the understanding of key ecological and evolutionary processes such as immigration-extinction dynamics (MacArthur \& Wilson, 1967). According to the equilibrium theory of island biogeography (MacArthur \& Wilson, 1967) island area and geographical isolation are the major factors predicting the islands' species numbers. Along with these factors, habitat heterogeneity has emerged as another important variable influencing species richness of oceanic islands (Rosenzweig, 1995). Island biogeographical models have been reviewed by several authors (Heaney, 2000, Losos \& Ricklefs 2009) who showed that factors such as island age, disturbance history, but also species traits may affect species richness on islands. Environmental and physical predictors have recently also been shown to be important for the prediction of plant biodiversity in 17,883 islands (Weigelt, Jetz, \& Kreft, 2013) and small mammals (Udy et al., n.d.) worldwide.

So far, oceanic islands have been the main study objects of island biogeography. While these islands are geologically stable and often distant from the mainland, there are also islands that consist of rather mobile sediments and occur closer to the shorelines. About 2,149 of these so-called barrier islands (Hayes M.O., 1979) occupy c. 20,783 kilometres of worldwide shorelines. Almost 20 percent of worldwide barrier islands extend along the coastline of the Atlantic Ocean and the Gulf of Mexico (Stutz \& Pilkey, 2011).

The East Frisian Islands (Germany) form a chain of barrier islands along the midEuropean coastline of the North Sea. These islands never had contact to the mainland and have also not been formed around mainland cores. Due to their independence from mainland, they offer an opportunity to study species distribution of floral and faunal organisms along a longitudinal coast line gradient (all islands oriented as a string of islands).

In the present study, we consider ten barrier islands for which we compiled an unprecedented dataset on biodiversity, habitat types and several centuries of expansion processes. Processes of island growth have been described from 1650 onwards (Petersen \& Pott 2005, Niedringhaus et al. 2008, Homeier et al. 2010, figure 1). Former studies on species-area relationships often analyzed responses of only a few taxa and only few island characteristics (e.g. MacArthur \& Wilson 1967, Kier et al. 2009, Franzén et al. 2012), whereas we included 36 taxa and a wealth of island features into our approach. 


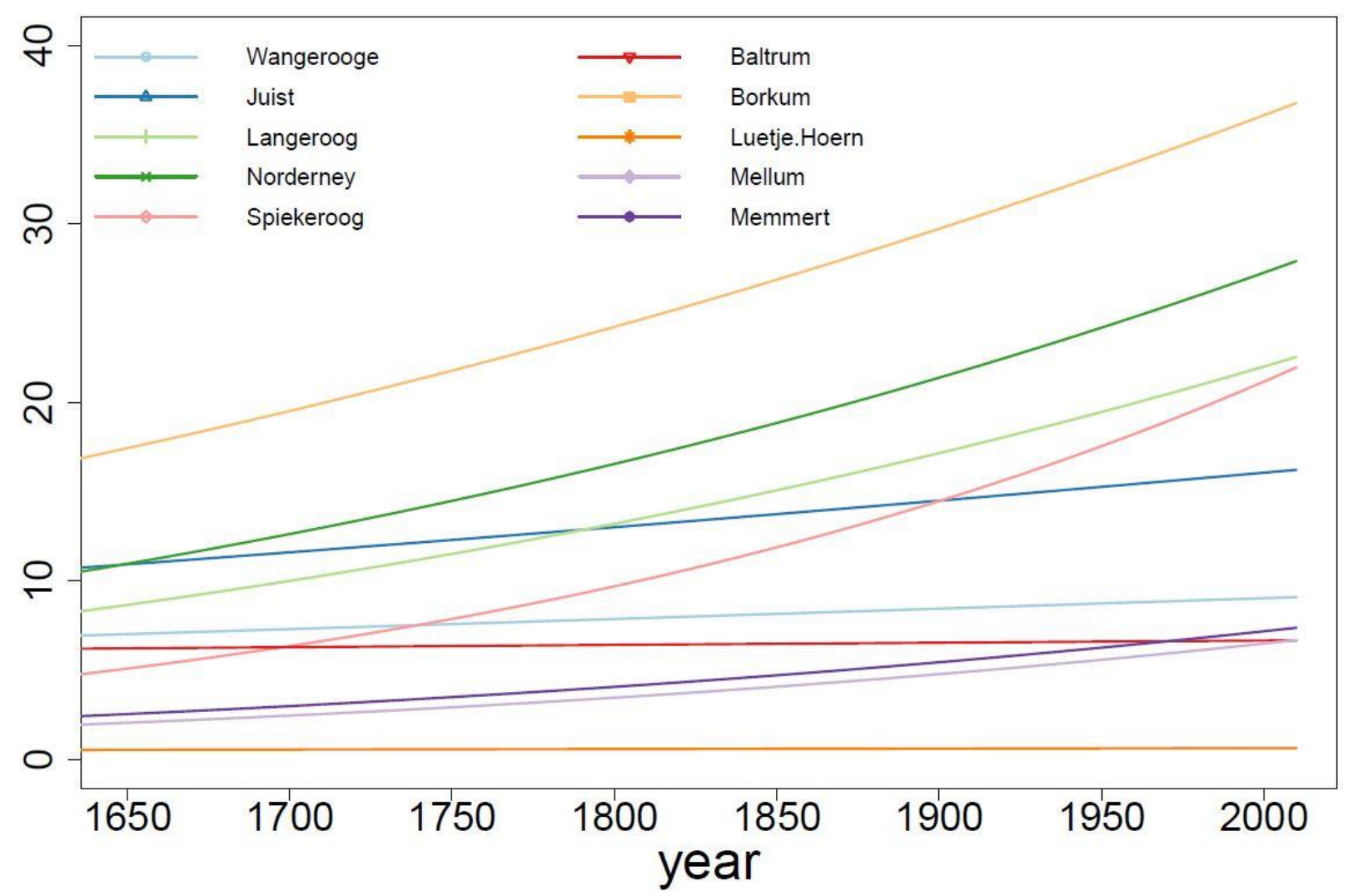

Figure 1 Increase of island size for each East Frisian Island from 1650 to 2008. The graph reflects an overview of all islands except the Minsener Oog. The differently colored lines stand for one island each. The island Luetje Hoern showed s small decline in island growth between 1960 and 2000, as it had been nearly destroyed by a tidal storm event in 1976. All of the other islands demonstrate an increase in island growth over 400 years.

Assuming that ontogenetic island data should be important for island species richness, we hypothesize:

(1) Current species richness of barrier islands is significantly influenced by island characteristics such as annual sedimentation rates.

(2) Habitat heterogeneity of islands calculated by Shannon index has a greater impact on species richness than area.

\section{Material and Methods}

\section{Study area}

The study area is located at the coastal line of the Northwestern state of Lower Saxony (Germany, 53 $35^{\prime} 17^{\prime \prime} \mathrm{N}, 6^{\circ} 40^{\prime} 11^{\prime \prime} \mathrm{E}-53^{\circ} 43^{\prime} 16^{\prime \prime} \mathrm{N}, 8^{\circ} 8^{\prime} 58^{\prime \prime} \mathrm{E}$ ). This chain of barrier islands consists of eleven islands, of which ten islands have their natural origin exclusively from both sedimentation and erosion processes and annually occurring 
storm tides (Homeier et al. 2010, Petersen and Pott 2005, Streif 1990). Island formation started about 4,000 years ago (Atlantic to Subboreal part of the Holocene Epoch). Extreme disturbances mainly driven by storms and intertidal changes formed a unique landscape with large colonies of breeding sea birds and seals in the Northern Sea, which belongs to the UNESCO World Heritage Site 'Lower Saxon Wadden Sea National Park' since 1993.

\section{Island physiognomy}

For each island, we collected data for island-specific habitat types (e.g. grasslands, dykes, dunes, salt marshes, fresh water habitats) and the island size from 2008 (Niedringhaus et al. 2008). Island size varied from 0.1 to $38.9 \mathrm{~km}^{2}$ (Niedringhaus et al. 2008). We calculated the Shannon index of habitat types, retrieved the island sizes for the years of 1650, 1750, 1860, 1960 and 2008 from historical maps (Niedringhaus et al. 2008, Homeier et al. 2010) and calculated different aspects of island ontogeny (table 1). We measured the increase of island area over time and the minimal and maximal size of each island (described below). This allowed us to calculate the coefficient of variation (cv) of the different island sizes and the maximal erosion and sedimentation rate of island size changes as indicators of island disturbances (referred to as 'erosion' and 'sedimentation') as well as the range ('range of area change', see below). Sedimentation was defined as the maximal sediment increase per island from one time point (1650, 1750, 1860, 1960 or 2008) to another (range: $0.65-27.99 \mathrm{~km}^{2}$ ). Minimal disturbance was defined as the maximal island area decrease due to island erosion processes from one time point to another (range: -25.50 to $-0.45 \mathrm{~km}^{2}$ ). 'Range of island change' was calculated as the span between maximal sedimentation and maximal erosion for each island (range: $1.12-53.49 \mathrm{~km}^{2}$ ). These variables have been calculated for 10 East Frisian Islands, except the 'Minsener Oog', which is actually an artificial island established in the $19^{\text {th }}$ century. We used the R package 'nlme' in combination with a self-starting power model to fit the increase of annual island size via the formula $S=c^{*} A^{z}$, where ' $c$ ' is the intercepts and $\mathrm{z}$ the slope of island growth (referred as the parameter 'island growth'). All variables are described in table 1. 
Table 1 Overview of explanatory variables with their ranges and units. Area, heterogeneity and island growth emerged from PCA as most influencing parameters. Erosion, sedimentation and range of development are additional island parameters regarding sedimentation processes. Data derived from Niedringhaus et al. 2008 and Homeier, Stephan and Niemeyer (2010).

\begin{tabular}{|c|c|c|c|c|c|}
\hline parameter & abbreviation & variable & minimum & maximum & unit \\
\hline area & area & Area from 2008 & 0.10 & 38.90 & $\mathrm{~km}^{2}$ \\
\hline shanhab & heterogeneity & $\begin{array}{l}\text { shannon index of } \\
\text { habitat diversity }\end{array}$ & 1.02 & 2.44 & - \\
\hline increase & island growth & $\begin{array}{l}\text { slope of linear } \\
\text { regression model } \\
\text { with area data } \\
\text { from } 1650 \text { to } \\
2008\end{array}$ & 0.35 & 7.41 & - \\
\hline $\mathrm{cV}$ & $\mathrm{cV}$ & $\begin{array}{l}\text { coefficient of } \\
\text { variation (cv) of } \\
\text { island area } \\
\text { between } 1650- \\
2008 \\
\end{array}$ & 6.14 & 66.51 & $\mathrm{~km}^{2}$ \\
\hline erosion & erosion & $\begin{array}{l}\text { starting from } \\
\text { 1650: maximal } \\
\text { amount of erosion }\end{array}$ & -25.50 & -0.45 & $\mathrm{~km}^{2}$ \\
\hline sedimentation & sedimentation & $\begin{array}{l}\text { starting from } \\
\text { 1650: maximal } \\
\text { amount of } \\
\text { sedimentation }\end{array}$ & 0.65 & 27.99 & $\mathrm{~km}^{2}$ \\
\hline delta & range of area change & $\begin{array}{l}\text { sedimentation } \\
\text { minus erosion }\end{array}$ & 1.12 & 53.49 & $\mathrm{~km}^{2}$ \\
\hline
\end{tabular}

\section{Plant and animal biodiversity data}

In 2009, the Wadden Sea National Park authorities published a summary of island biodiversity across a wide range of taxa, dating from the early $20^{\text {th }}$ century up to now (Niedringhaus et al. 2008). This dataset documents presence or absence data of more than 9,000 species with about 6,926 extant species. In the present analysis, we consider species recorded for the period after 1976. We classified taxa into 36 taxonomical groups from lichens up to mammals of 10 East Frisian Islands. The dataset of the island Minsener Oog had to be scrapped. This island had been artificially built as a tidal power plant and therefore has been artificially planted and colonized. Further details can be found in Niedringhaus et al. 2008. For statistical reasons, we considered only taxa that were present on at least three islands. This resulted in 3,011 species used in further analyses.

\section{Statistical Analyses}

Data were analyzed using R 3.2.1. (R Development Core Team 2015). We started with a Principal Component Analysis for all island parameters (Table 1) as an exploratory tool to select the following three largely independent groups of explanatory variables (i.e. 
orthogonal in PCA space): (1) island changes between 1650 and 2008 (sedimentation, erosion, island growth, island area variation, range of area change), (2) habitat heterogeneity and (3) island area. We log-transformed erosion, sedimentation and range of area change to reduce leverage in statistical models. In the end seven parameters have been chosen (Table 2).

We then set up separate generalized linear mixed-effects models (R package lme4, version 1.1-12, Bates et al. 2015, Fox 2003) for each taxon with binomial presence/absence of each individual taxon as the response variable, and island as a random effect. Fixed-effects terms were all pairwise combinations of uncorrelated explanatory variables from the three main groups (habitat heterogeneity, area and island changes between 1650 and 2008). Overall, we set up 20 models including main parameters (heterogeneity, area, coeffizient of island size variation between 1650 and 2008 (cv) and island growth), additional explanatory variables (sedimentation, erosion and range of development), combinations of these variables and a null model (Table 2). These explanatory variables were entered as fixed effects, while island was entered as random effect. For each taxon, we generated a total of 20 models and compared them using Akaike's information criterion, corrected for small sample sizes (AICc). In our final set of best models, we included models whose AICs differed by 2 from the minimum value of AIC (after Burnham \& Anderson 2002) to assess models around the best fitting model (S1). We inspected model residuals for constant variance and normality.

As parameter estimates were on a logit scale, we back-transformed predictions for easier interpretation.

Table 2 Outputs of the best fitting model after use of AICc for every taxon, its intercept, effect sizes for related variables and significance of taxon influence. Three types of variable groups had been used: classical variables from Island Biogeography (area, habitat heterogeneity) and a newly established variable 'island growth'. Secondly, additional ontogenetic island variables erosion, sedimentation and range of development are used to explain species richness. Additionally, combined models fall into one of the previous described variables and an additional ontogenetic island variable (erosion, sedimentation and range of development). Species richness of most of the taxa can be explained via habitat heterogeneity, second most by area and thirdly by the parameter island growth.

Plants

\begin{tabular}{|l|l|l|l|l|l|l|}
\hline taxon & variable & Intercept & value & Std.Dev. & p-value & significance \\
\hline Bryophyta $(\mathrm{n}=109)$ & heterogeneity & -8.06 & 3.788 & 1.102 & 0 & $* * *$ \\
\hline Fern $(\mathrm{n}=8)$ & heterogeneity & -7.081 & 3.959 & 0 & 0 & $* * *$ \\
\hline Grass $(\mathrm{n}=120)$ & heterogeneity & -5.522 & 3.381 & 0.381 & 0 & $* * *$
\end{tabular}




\begin{tabular}{|l|l|l|l|l|l|l|}
\hline taxon & variable & Intercept & value & Std.Dev. & p-value & significance \\
\hline \multirow{2}{*}{ Herbs (n=397) } & heterogeneity & 5.6 & -2.94 & 0.409 & 0 & $* * *$ \\
& sedimentation & 5.6 & 0.308 & 0.409 & 0.123 & n.s. \\
\hline \multirow{2}{*}{ Lichen (n=94) } & area & -4.328 & 0.348 & 1.909 & 0 & $* * *$ \\
& sedimentation & -4.328 & -1.716 & 1.909 & 0.087 &. \\
\hline \multirow{2}{*}{ Shrubs (n=32) } & erosion & -7.347 & 0.404 & 0.269 & 0.161 & n.s. \\
& heterogeneity & -7.347 & 3.869 & 0.269 & 0 & $* * *$ \\
\hline Trees (n=45) & heterogeneity & -8.464 & 4.47 & 0.324 & 0 & $* * *$ \\
\hline
\end{tabular}

Vertebrata

\begin{tabular}{|l|l|l|l|l|l|l|}
\hline Amphibia (n=3) & heterogeneity & -6.527 & 3.355 & 0 & 0.015 & $*$ \\
\hline Aves (n=142) & heterogeneity & -1.747 & 2.101 & 0.871 & 0.002 & $* *$ \\
\hline \multirow{2}{*}{ Mammalia (n=12) } & erosion & -11.827 & 0.81 & 0 & 0.143 & n.s. \\
& heterogeneity & -11.827 & 5.714 & 0 & 0 & $* * *$ \\
\hline Osteichthyes (n=4) & area & -2.801 & 0.194 & 0 & 0.001 & $* * *$ \\
\hline
\end{tabular}

Invertebrata

\begin{tabular}{|c|c|c|c|c|c|c|}
\hline Acari $(n=2)$ & area & -1.175 & 0.095 & 0 & 0.068 & . \\
\hline Araneae (n=173) & $\begin{array}{l}\text { erosion } \\
\text { area }\end{array}$ & $\begin{array}{l}-0.089 \\
-0.089\end{array}$ & $\begin{array}{l}-0.709 \\
0.096\end{array}$ & $\begin{array}{l}0.771 \\
0.771\end{array}$ & $\begin{array}{l}0.06 \\
0\end{array}$ & *** \\
\hline $\begin{array}{l}\text { Auchenorrhyncha } \\
(\mathrm{n}=131)\end{array}$ & heterogeneity & -5.079 & 3.172 & 0.384 & 0 & $* * *$ \\
\hline Brachycera (n=159) & $\begin{array}{l}\text { erosion } \\
\text { island growth }\end{array}$ & $\begin{array}{l}-3.26 \\
-3.26\end{array}$ & $\begin{array}{l}0.877 \\
0.405\end{array}$ & $\begin{array}{l}1.196 \\
1.196\end{array}$ & $\begin{array}{l}0.082 \\
0.019\end{array}$ & * \\
\hline $\begin{array}{l}\text { Coleoptera (aquatic, } \\
\mathrm{n}=94 \text { ) }\end{array}$ & $\begin{array}{l}\text { heterogeneity } \\
\text { range of area } \\
\text { change }\end{array}$ & $\begin{array}{l}-7.94 \\
-7.94\end{array}$ & $\begin{array}{l}3.612 \\
0.641\end{array}$ & $\begin{array}{l}0.525 \\
0.525\end{array}$ & $\begin{array}{l}0 \\
0.013\end{array}$ & $\begin{array}{l}\text { *** } \\
*\end{array}$ \\
\hline $\begin{array}{l}\text { Coleoptera } \\
\text { (Carabidae, } n=116 \text { ) }\end{array}$ & heterogeneity & -2.685 & 1.687 & 0.65 & 0.001 & $* * *$ \\
\hline $\begin{array}{l}\text { Coleoptera (other, } \\
n=194)\end{array}$ & $\begin{array}{l}\text { erosion } \\
\text { heterogeneity }\end{array}$ & $\begin{array}{l}-8.365 \\
-8.365\end{array}$ & $\begin{array}{l}1.214 \\
3.201\end{array}$ & $\begin{array}{l}0.962 \\
0.962\end{array}$ & $\begin{array}{l}0.004 \\
0\end{array}$ & $\begin{array}{l}* * \\
* * *\end{array}$ \\
\hline $\begin{array}{l}\text { Coleoptera } \\
\text { (phytophagous, } \\
n=131 \text { ) }\end{array}$ & $\begin{array}{l}\text { erosion } \\
\text { heterogeneity }\end{array}$ & $\begin{array}{l}-16.71 \\
-16.71\end{array}$ & $\begin{array}{l}-0.851 \\
8.491\end{array}$ & $\begin{array}{l}0.81 \\
0.81\end{array}$ & $\begin{array}{l}0.029 \\
0\end{array}$ & $\begin{array}{l}* \\
* * *\end{array}$ \\
\hline $\begin{array}{l}\text { Coleoptera } \\
\text { (Staphylinidae, } \\
n=322 \text { ) }\end{array}$ & island growth & -1.686 & 0.518 & 0.844 & 0 & $* * *$ \\
\hline Crustacea $(n=42)$ & heterogeneity & -5.484 & 2.731 & 1.406 & 0.025 & $*$ \\
\hline Gastropoda (n=13) & heterogeneity & -5.973 & 2.918 & 0.327 & 0 & $* * *$ \\
\hline Heteroptera $(n=180)$ & $\begin{array}{l}\text { erosion } \\
\text { heterogeneity }\end{array}$ & $\begin{array}{l}-4.867 \\
-4.867\end{array}$ & $\begin{array}{l}0.34 \\
2.571\end{array}$ & $\begin{array}{l}0.454 \\
0.454\end{array}$ & $\begin{array}{l}0.115 \\
0\end{array}$ & $\begin{array}{l}\text { n.s. } \\
* * *\end{array}$ \\
\hline $\begin{array}{l}\text { Hymenoptera } \\
\text { (Apiformes, } n=101 \text { ) }\end{array}$ & heterogeneity & -6.833 & 3.883 & 0.692 & 0 & $* * *$ \\
\hline $\begin{array}{l}\text { Hymenoptera } \\
\text { (Formicidae, } n=20 \text { ) }\end{array}$ & heterogeneity & -4.857 & 3.103 & 0.25 & 0 & $* * *$ \\
\hline
\end{tabular}




\begin{tabular}{|l|l|l|l|l|l|l|}
\hline taxon & variable & Intercept & value & Std.Dev. & p-value & significance \\
\hline $\begin{array}{l}\text { Hymenoptera (Non- } \\
\text { Apiformes, } \mathrm{n}=116)\end{array}$ & erosion & -6.959 & 0.491 & 0.485 & 0.04 & $*$ \\
& heterogeneity & -6.959 & 3.441 & 0.485 & 0 & $* * *$ \\
\hline Lepidoptera (n=81) & heterogeneity & -8.019 & 3.687 & 2.336 & 0.073 &. \\
\hline Odonata (n=25) & heterogeneity & -7.932 & 4.114 & 1.587 & 0.007 & $* *$ \\
\hline Symphyta (n=119) & erosion & -8.519 & 0.238 & 0.119 & 0.058 &. \\
& heterogeneity & -8.519 & 4.301 & 0.119 & 0 & $* * *$ \\
\hline Trichoptera (n=5) & heterogeneity & -5.642 & 2.727 & 0.978 & 0.053 &. \\
\hline
\end{tabular}

Effect sizes of parameter influence were calculated for a subset of 30 taxa because of too large Eigenvalues in the remaining six taxa.

\section{Results}

Model selection for generalized linear mixed-effect models for all taxa yielded minimal adequate models for each taxon (S2). For 10 East Frisian Islands, 30 taxa with 3,011 species were analysed (table 2, figure 2). Habitat heterogeneity had an effect on 24 taxa, whereas island area influenced 4 taxa only. The annual island growth had a positive effect on two taxa: Staphylinidae and Brachycera. One third (12 out of 36 total taxa) of analysed taxa could be explained by parameters of barrier island changes (sedimentation, erosion and range of area change). For Blattodea, the null model was the minimal adequate model. Only Dermaptera did not respond to any of the analysed predictor variables.

The occurrence probability for each taxon was calculated by taking inverse logits. For taxa driven mainly by habitat heterogeneity, the occurrence probability ranged between 90 and 100\%. Heterogeneity models with an additional island characteristic co-variable split into three groups: erosion resulted in probabilities between 30 and 77\%, sedimentation between $58-73 \%$ and the difference between erosion and sedimentation with one value of $66 \%$. Habitat heterogeneity influenced most taxa including plants and animals. Four area driven taxa (Acari, Araneae, Lichen and Osteichthyes) are supplemented by the additional variables erosion (occurrence probability: 33\%) and sedimentation (occurrence probability: 15\%). Only two taxa are influenced by island growth, describing 60 and $63 \%$ of occurrence probability. In contrast to rove beetles, flies are additionally described by island erosion, explaining $70 \%$ of taxon occurrence probability. 


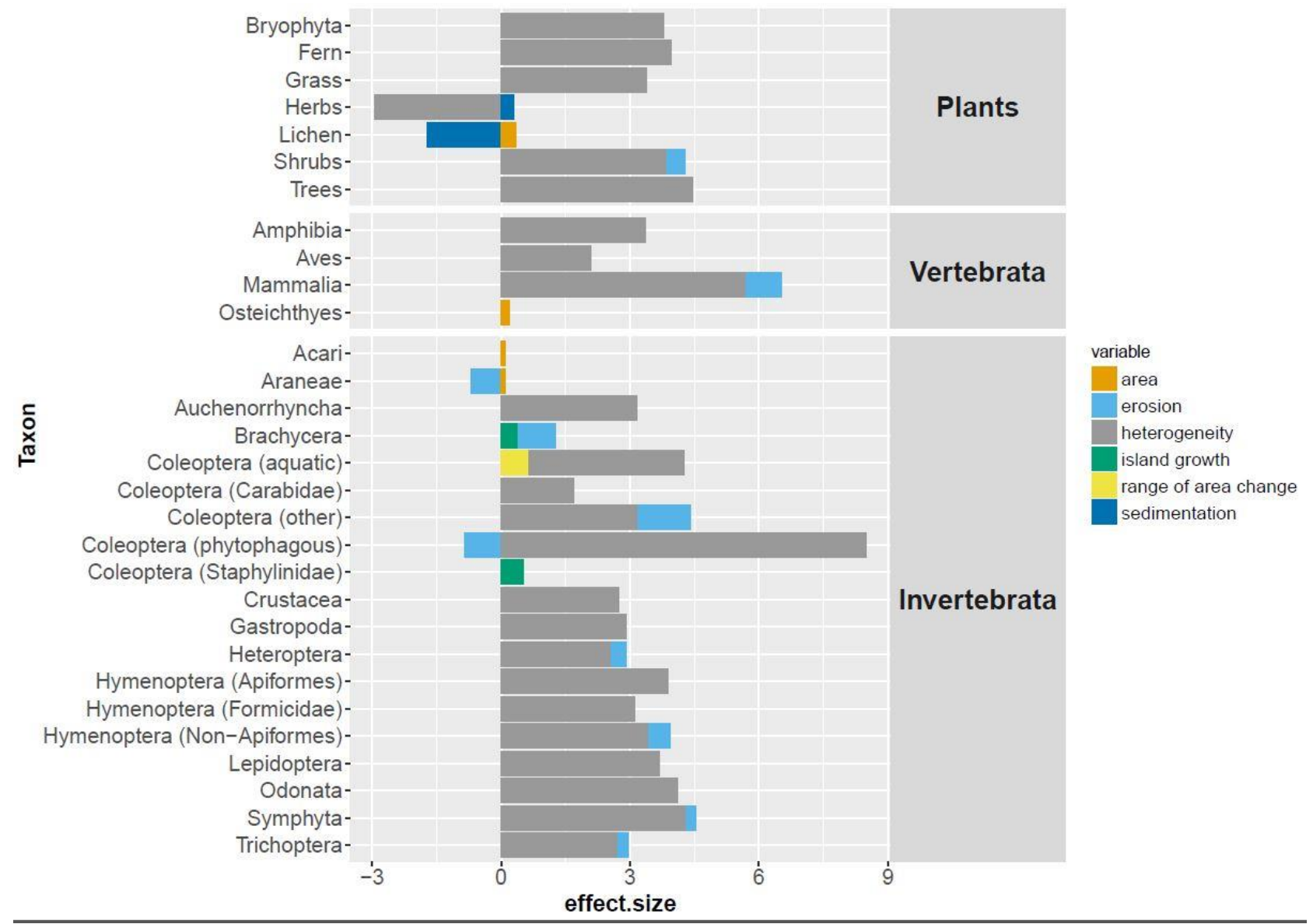

Figure 2 Effect sizes on species richness of 30 taxa. 14 taxa respond significantly to habitat heterogeneity. In addition, 10 taxa react to habitat heterogeneity in interaction with an island specific variable. Species richness of lichen, mites, reptiles and spiders can be explained by current island area. The influence of island growth on rove beetles and Brachycera is also shown. In both taxa, species richness is significant positively influenced by this ontogenetic island parameter. Different colours stand for different parameters: green (habitat heterogeneity), red (area), purple (island growth), blue (erosion), yellow (sedimentation) and orange (range of island change). The $\mathrm{x}$-axis gives the effect sizes, reflecting the strength of response of taxa to parameters included in the best fitting model. The higher the effect size, the higher the influence on the taxon.

\section{Discussion}

The East Frisian Islands cover a range of distinct habitat types (e.g. old lower salt marshes, coastal dune valleys, swamps) offering a manifold of breeding, hunting and mating habitats. In the present study covering 36 taxa from ten German barrier islands, island area turned out be much less important than habitat heterogeneity. Interestingly, island changes contributed to the explanation of richness of ten taxa, while the majority 
of taxa were related to the island's habitat heterogeneity. This result supports the importance of environmental habitat heterogeneity in comparison to classical speciesarea-relationship. Species richness distribution can be produced by both neutral and niche theory processes, where environmental heterogeneity is a proxy for niche theory and area for neutral theory (Pyšek et al. 2002, Tews et al. 2004, Udy et al., n.d.). Tews and colleagues argued that environmental heterogeneity enhances species richness through increased variation in resources, structural complexity or environmental conditions (Tews et al. 2004). As niche theory includes ecological niches and variables, neutral theory only refer to area, where dispersal and speciation rates are constant (Udy et al., n.d.). Studies supporting neutral theory state that individuals of the same trophic level have equal values of fitness and communities of these individuals are built by species assemblages where their presence is led by ecological drift, random speciation and dispersal (Udy et al., n.d.). In summary, neutral theory does not involve ecological niches (Field et al. 2009). Taxa of our studies are mainly influenced by habitat heterogeneity and most importantly, our study implies the important influence of barrier island specific characteristics, such as erosion and sedimentation processes over time. For 13 taxa, these additional factors were related to the occurrence of certain taxa on the East Frisian Islands. We therefore can also proof the importance of niche theory for species distribution on the East Frisian Islands.

Barrier islands are influenced by strong and daily occurring disturbance processes such as tidal change and storm effects. Barrier islands, which are established after tide events following strong storms, can be completely destroyed because they are only built by offshore sedimentation processes (Niedringhaus et al. 2008, Bartholomä et al. 2009). Compared to oceanic archipelagos, the German barrier islands change their shape annually - both sedimentation and erosion processes have a huge impact. Several authors argue that species richness of coastal dune habitats of barrier islands is influenced by environmental factors such as frequent disturbance events, steep environmental gradients and inundation events (Fahrig et al. 1993, Houle 2008, da Silva et al. 2008, Gornish and Miller 2010 and Brantley et al. 2014). The maps of Homeier et al. 2010 give an unique possibility to quantify barrier island growth for more than 400 years. Compared to other studies (e.g. Bartholomä et al. 2009), we had the possibility to analyse island characteristics due to island sedimentation processes for a large period of 
time. It is obvious from these maps, that the seven large East Frisian Islands (Borkum, Juist, Norderney, Baltrum, Langeoog, Spiekeroog and Wangerooge) have some prominent similarities: they are equal in their geomorphological development, have the same habitat structure from North to South and are highly disturbed my human beings for over two centuries (Petersen and Pott 2005, Niedringhaus et al. 2008). Nevertheless, they have completely different island sizes, habitat heterogeneity and island age. Naturally occurring island shift is highly but equally disturbed by human constrains like island fixing structures at the western part of each island, dikes, and dune fixation (Niedringhaus et al. 2008). Mass tourism and planting non-native plants are ecological challenging aspects which additionally influence island communities.

In our analysis, 10 of our 36 taxa are influenced by annually occurring sedimentation or erosion processes. Based on annual sedimentation and storm tide events (Peters \& Pott 2005, Niedringhaus et al. 2008), dissolved organic matter in sea water supplies plant growth in coastal habitat systems (Rossel et al. 2013). This nutrition effect enhances the amount of soil organic matter and therefore the turnover of soil microbial communities (Morrissey et al. 2014). Additionally, salinity also has a huge impact of microbial community composition and therefore the production of soil organic matter in tidal wetlands (Morrissey et al. 2014). Herbaceous plants are almost exclusively negatively influenced by habitat heterogeneity and to a non-significant extent driven by sedimentation processes in our dataset. As herbaceous plants are directly or indirectly the main food resource for animal taxa, annual sedimentation events support plant communities with dissolved organic matter and therefore indirectly influence coastal animal communities and nutrient cycles (Lindh et al. 2015).

Most of the species diversity of terrestrial animals is driven by habitat heterogeneity (Tews et al. 2004). The really special low degree of isolation of the East Frisian Islands from the mainland may explain that most of the taxa are influenced by habitat heterogeneity. Due to the high habitat heterogeneity of the analysed barrier islands compared to neighboured mainland area (Zdrakovic 2008, Lott et al. 2009), food availability is enhanced and attracts diversity of consumers. The high heterogeneity of major resources support the uniqueness and conservation value of the East Frisian Islands as an outstanding retreat area for an amazing biodiversity. 


\section{References}

Báldi, A. (2008): Habitat heterogeneity overrides the species-area relationship, Journal of Biogeography 35: 675:681.

Bartholomä, A., Kubicki, A., Badewien, T.H. and Flemming, B.W. 2009: Suspended sediment transport in the German Wadden Sea-seasonal variations and extreme events, Ocean Dynamics 59: 213-225.

Bates, D., Maechler, M. Bolker, B. and Walker, S. 2015: Fitting Linear Mixed-Effects Models Using lme4. Journal of Statistical Software, 67(1), 1-48.

Brantley ST, Bissett SN, Young DR, Wolner CWV, Moore LJ 2014: Barrier Island Morphology and Sediment Characteristics Affect the Recovery of Dune Building Grasses following Storm-Induced Overwash. PLoS ONE 9(8): e104747.

da Silva GM, Hesp P, Peixoto J, Dillenburg SR (2008) Foredune vegetation patterns and alongshore environmental gradients: Mocambique beach, Santa Catarina Island, Brazil. Earth Surf Proc Land 33: 1557-1573.

Fahrig, L., Hayden, B. and Dolan, R. (1993) Distribution of Barrier Island Plants in Relation to Overwash Disturbance: A Test of Life History Theory, Journal of Coastal Research 9(2): 403-412.

Field, R., Hawkins, B.A., Cornell, H.V., Currie, D.J., Diniz-Filho, J.A.F., Guégan, J.F., Kaufman, D.M., Kerr, J.T., Mittelbach, G.G., Oberdorff, T., O’Brien, E.M. and Turner, J.R.G. (2009): Spatial species-richness gradients across scales: A meta-analysis. Journal of Biogeography 36: 132-147.

Fox, J. (2003). Effect Displays in R for Generalised Linear Models. Journal of Statistical Software, 8(15), 1-27. URL http://www.jstatsoft.org/v08/i15/.

Franzén M, Schweiger O, Betzholtz P-E (2012) Species-Area Relationships Are Controlled by Species Traits. PLoS ONE 7(5): e37359. 
Gornish ES, Miller TE (2010) Effects of storm frequency on dune vegetation. Glob Change Biol 16: 2668-2675.

Hawkins, B.A., Field, R., Cornell, H.V., Currie, D.J., Guégan, J.A.F., Kaufman, D.M., Kerr, J.T., Mittelbach, G.G., O’Brien, E.M., Porter, E.E. and Turner, J.R.G. (2003): Energy, water, and broadscale geographic patterns of species richness. Ecology 84: 3105-3117.

Hayes MO (2005) Barrier Islands. In: Schwartz ML (ed) Encyclopedia of Coastal Science. Springer Netherlands, Dordrecht, pp 117-119

Homeier, H., Stephan, H.-J. and Niemeyer, D. (2010) Niedersächsischer Landesbetrieb für Wasserwirtschaft, Küsten- und Naturschutz (NLWKN), Forschungsstelle Küste (editor) 2010: Historisches Kartenmaterial nach Homeier, Berichte der Forschungsstelle Küste ; 43/2010, 1st edition, NLWKN, Hannover.

Houle G (2008) Plant species richness and its determinants on a coastal dune system at Iles de la Madeleine, Quebec (Canada). Ecoscience 15: 113-120.

Lindh, M. V., Lefébure, R., Degerman, R., Lundin, D., Andersson, A., \& Pinhassi, J. (2015). Consequences of increased terrestrial dissolved organic matter and temperature on bacterioplankton community composition during a Baltic Sea mesocosm experiment. Ambio, 44(Suppl 3), 402-412.

Losos, J.B. and Ricklefs, R. E. (2009) The Theory of Island Biology Revisited, Princeton University Press, $1^{\text {st }}$ edition, Princeton.

Lott, C.A., Ewell, C.S. Jr. and Volansky, K.L. (2009) Habitat Associations of ShorelineDependent Birds in Barrier Island Ecosystems During Fall Migration in Lee County, Florida, Dredging Operations and Environmental Research Program, U.S. Army Corps of Engineers, Washington, DC

MacArthur, R. H. and Wilson, E.O. (1967) The Theory of Island Biogeography, Princeton Landmarks in Biology, 13 th edition (2001), Princeton. 
Niedringhaus, R., Haeseler, V., Janiesch, P. (eds) (2008) Die Flora und Fauna der Ostfriesischen Inseln - Einführung in das Projekt „Biodiversität im Nationalpark Niedersächsisches Wattenmeer“ - Schr.R. Nationalpark Nieders. Wattenmeer 11.

Petersen, J. and Pott, R. (2005) Ostfriesische Inseln: Landschaft und Vegetation im Wandel, 1st edition, Schlütersche, Hannover.

Pyšek , P., Kučera, T. and Jarošík (2002): Plant species richness of nature reserves: The interplay of area, climate and habitat in a central European landscape. Global Ecology and Biogeography 11: 279-289.

Rosenzweig, M.L. (1995): Species diversity in space and time, University of Cambridge Press, Cambridge.

Rossel PE, Vähätalo AV, Witt M and Dittmar T (2013) Molecular composition of dissolved organic matter from a wetland plant (Juncus effusus) after photochemical and microbial decomposition (1.25 yr): Common features with deep sea dissolved organic matter. Organic Geochemistry 60, 62-71.

Streif, H. (1990) Das Ostfriesische Küstengebiet, Nordsee, Inseln, Watten und Marschen, Sammlung Geologischer Fuehrer, Gebrueder Borntraeger Verlag, 2nd edition, Berlin, Stuttgart.

Stutz, M. L. and Pilkey, O.H. (2011) Open-Ocean Barrier Islands: Global Influence of Climatic, Oceanographic, and Depositional Settings, Journal of Coastal Research 27(2): $207-222$.

Tews, J., Brose, U., Grimm, V., Tielbörger, K., Wichmann, M. C., Schwager, M. and Jeltsch, F. (2004), Animal species diversity driven by habitat heterogeneity/diversity: the importance of keystone structures. Journal of Biogeography, 31: 79-92. 
Udy, K., Fritsch, M., Grass, I., Hartig, F., Kneib,T., Kreft, H., Kukunda, C., Meyer, K.M., Pe'er, G., Reininghaus, H., Tietjen, B., Tscharntke, T., von Waveren, C.S. and Wiegand, K. (n.d.)

Weigelt, P., Jetz, W. and Kreft, H. (2013) Bioclimatic and physical characterization of the world's islands, PNAS 110(38): 15307-15312.

Zdravkovic, M.(2008) Beach-nesting Bird Breeding Census and Report for Coastal Alabama-2007 Report, Audubon Coastal Bird Conservation Program, Science Dept. National Audubon Society, New York, NY 
SUPPORTING INFORMATION

Chapter 2 


\section{Table S1 Overview over all run models}

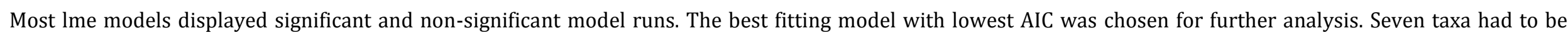

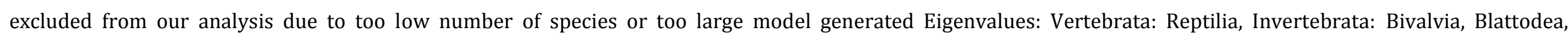
Dermaptera, Nematocera, Saltatoria and Siphonaptera.

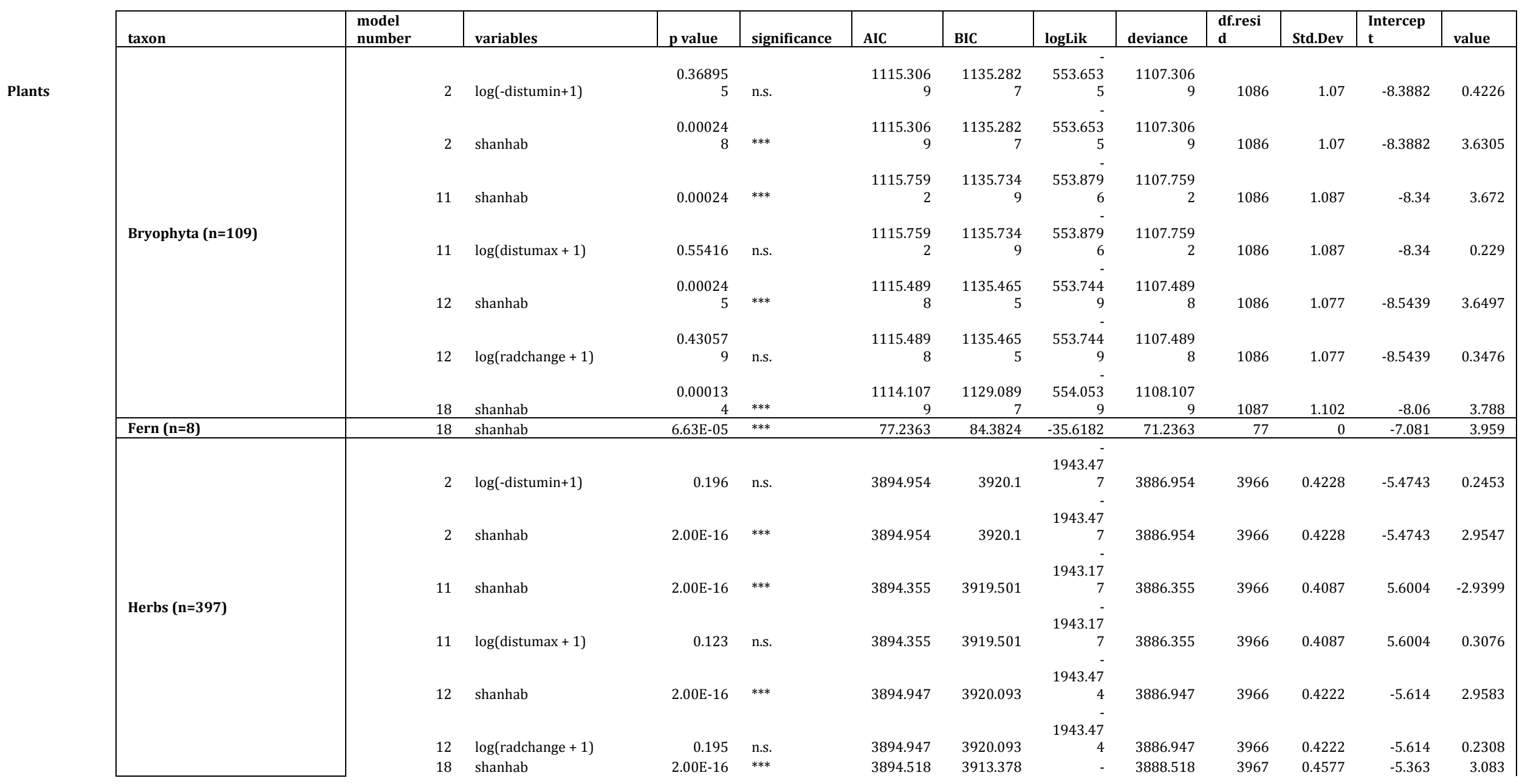




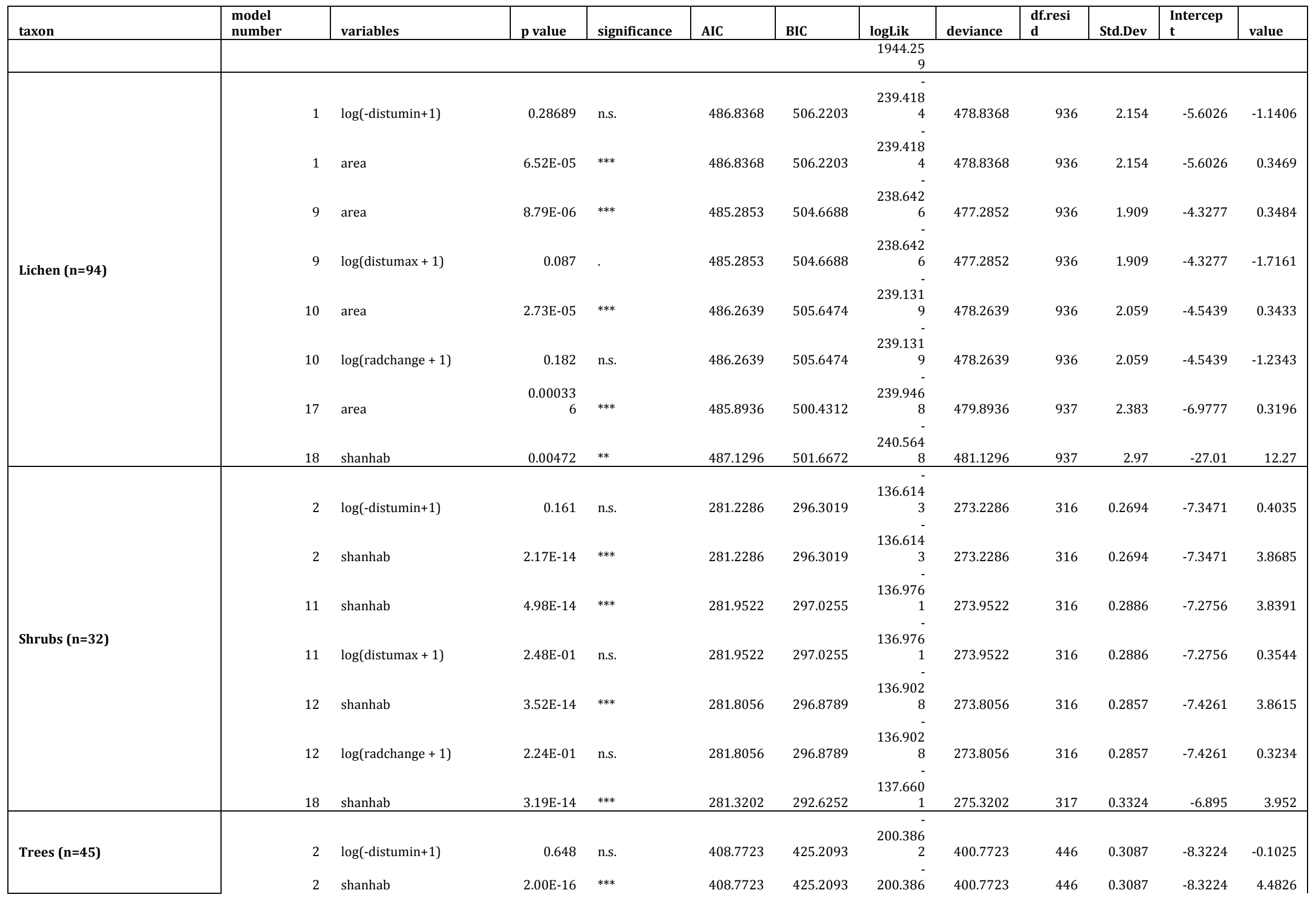




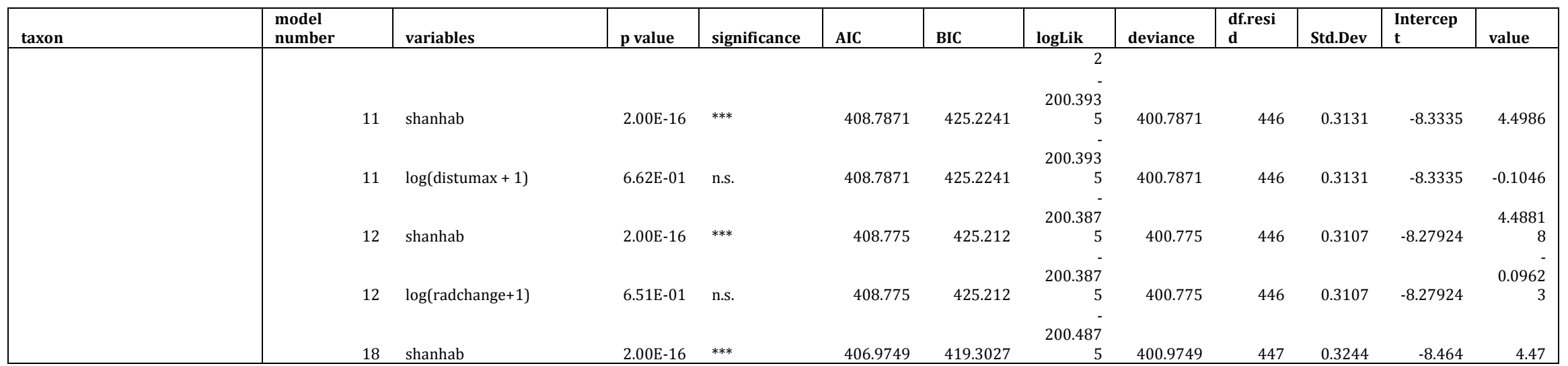

\section{Vertebrata}

\begin{tabular}{|c|c|c|c|c|c|c|c|c|c|c|c|c|}
\hline \multirow{2}{*}{ Amphibia ( $n=3$ ) } & 18 & shanhab & 0.0145 & * & 37.9959 & 42.1995 & -15.9979 & 31.9959 & 27 & 0 & -6.527 & 3.355 \\
\hline & 19 & $\mathrm{cv}$ & 0.0144 & * & 39.8884 & 44.092 & -16.9442 & 33.8884 & 27 & 0 & 2.33223 & $\begin{array}{r}0.0566 \\
6\end{array}$ \\
\hline \multirow{9}{*}{ Aves ( $n=142)$} & 1 & $\log (-$ distumin+1) & 0.608 & n.s. & 912.5944 & 933.6281 & $\begin{array}{r}452.297 \\
2\end{array}$ & 904.5944 & 1416 & 0.8332 & 0.88138 & $\begin{array}{r}0.2234 \\
1\end{array}$ \\
\hline & 1 & area & 0.009 & ** & 912.5944 & 933.6281 & $\begin{array}{r}452.297 \\
2\end{array}$ & 904.5944 & 1416 & 0.8332 & 0.88138 & $\begin{array}{r}0.0754 \\
5\end{array}$ \\
\hline & 2 & $\log (-$ distumin+1) & 0.35164 & n.s. & 911.9413 & 932.975 & $\begin{array}{r}451.970 \\
7\end{array}$ & 903.9413 & 1416 & 0.8255 & -1.8744 & 0.3704 \\
\hline & 2 & shanhab & 0.00586 & ** & 911.9413 & 932.975 & $\begin{array}{r}451.970 \\
7\end{array}$ & 903.9413 & 1416 & 0.8255 & -1.8744 & 1.8855 \\
\hline & 9 & area & 0.00935 & $* *$ & 912.143 & 933.1767 & $\begin{array}{r}452.071 \\
5\end{array}$ & 904.143 & 1416 & 0.8114 & 0.58984 & $\begin{array}{r}0.0723 \\
6\end{array}$ \\
\hline & 9 & $\log (\operatorname{distumax}+1)$ & 0.38637 & n.s. & 912.143 & 933.1767 & $\begin{array}{r}452.071 \\
5\end{array}$ & 904.143 & 1416 & 0.8114 & 0.58984 & $\begin{array}{r}0.4007 \\
3\end{array}$ \\
\hline & 10 & area & 0.00774 & ** & 912.2435 & 933.2771 & $\begin{array}{r}452.121 \\
7\end{array}$ & 904.2435 & 1416 & 0.8135 & 0.56598 & $\begin{array}{r}0.0735 \\
6\end{array}$ \\
\hline & 11 & shanhab & 0.00534 & $* *$ & 911.3126 & 932.3462 & $\begin{array}{r}451.656 \\
3\end{array}$ & 903.3126 & 1416 & 0.8012 & -2.1254 & 1.8388 \\
\hline & 11 & $\log ($ distumax +1$)$ & 0.21184 & n.s. & 911.3126 & 932.3462 & 451.656 & 903.3126 & 1416 & 0.8012 & -2.1254 & 0.5319 \\
\hline
\end{tabular}




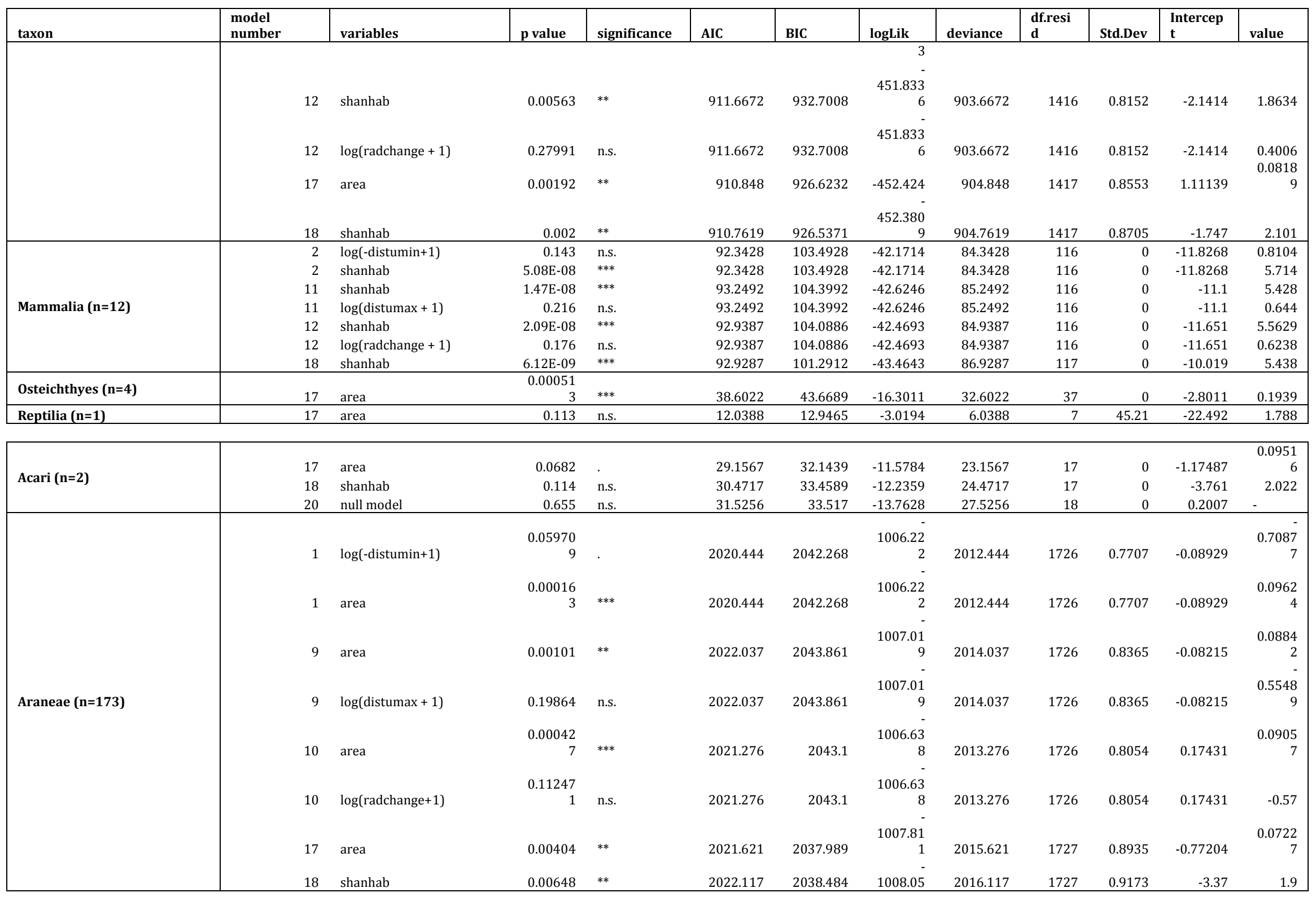




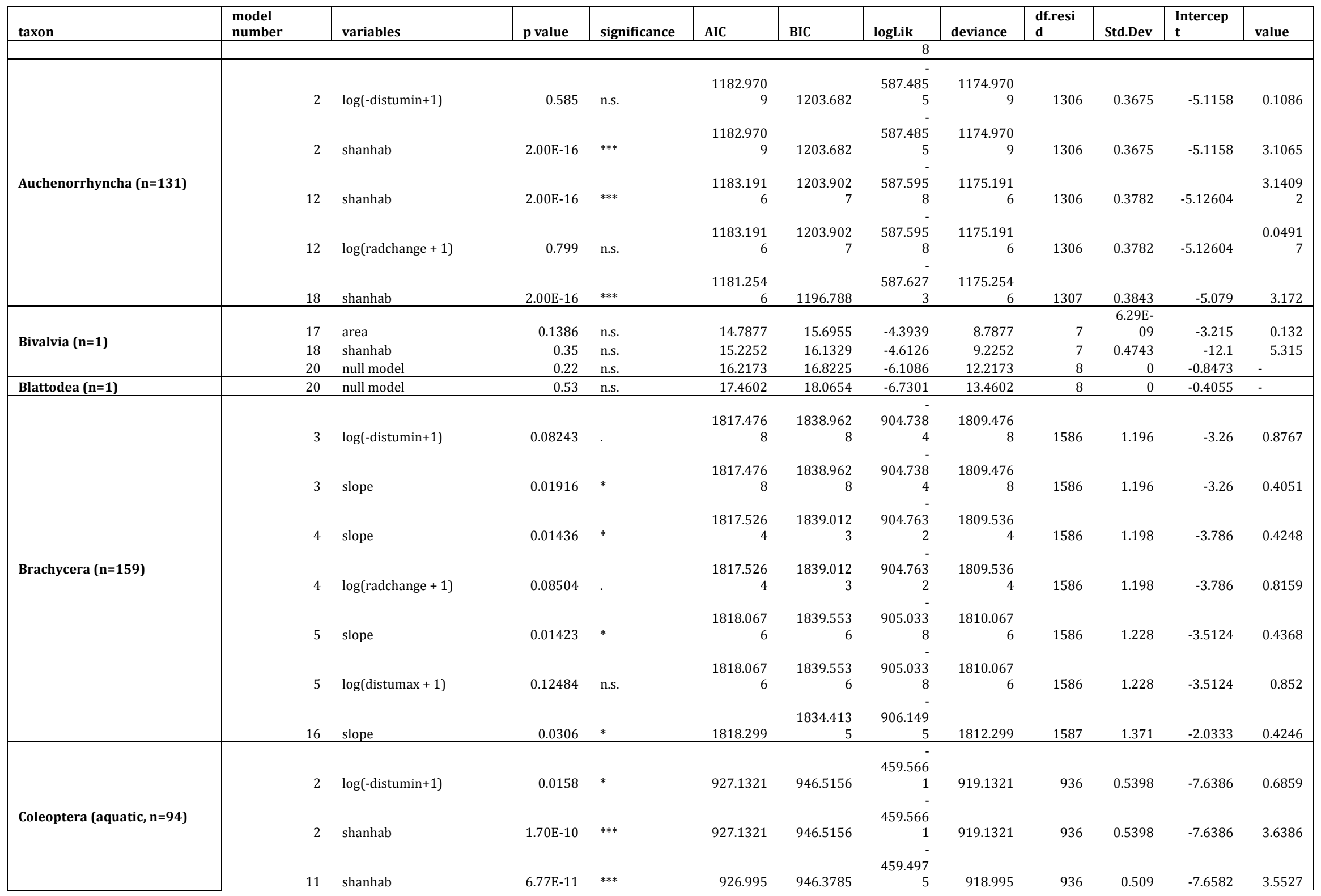




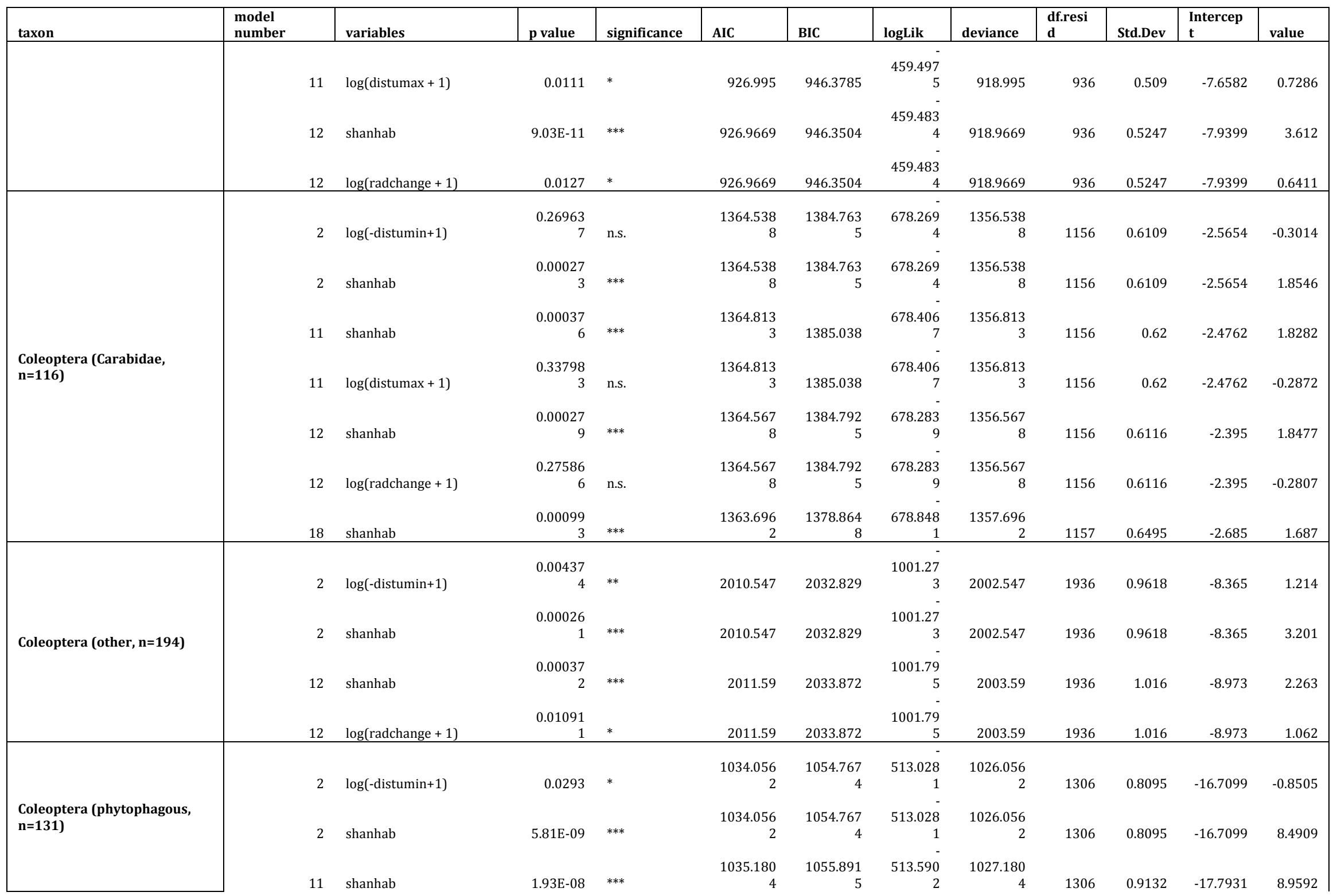




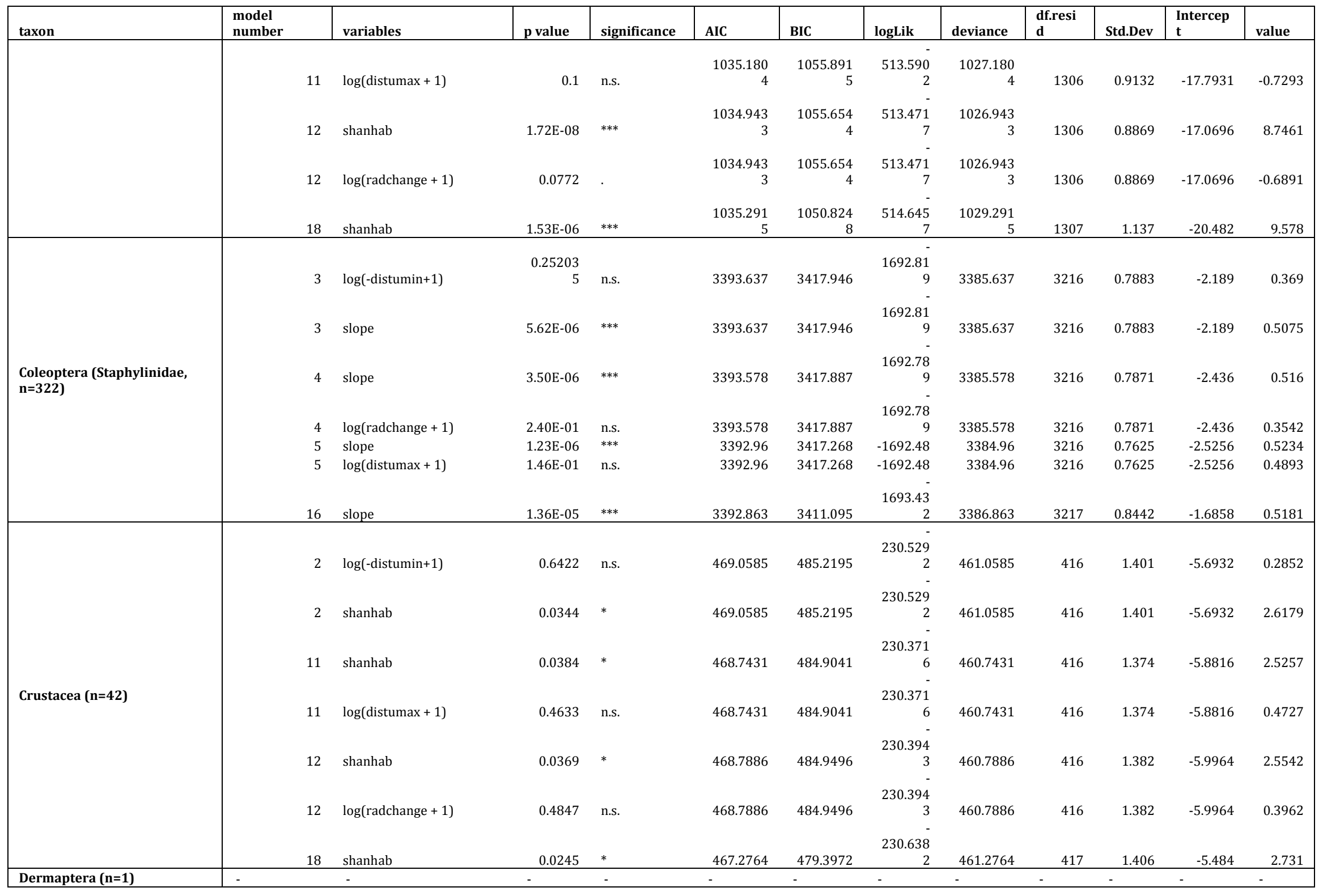




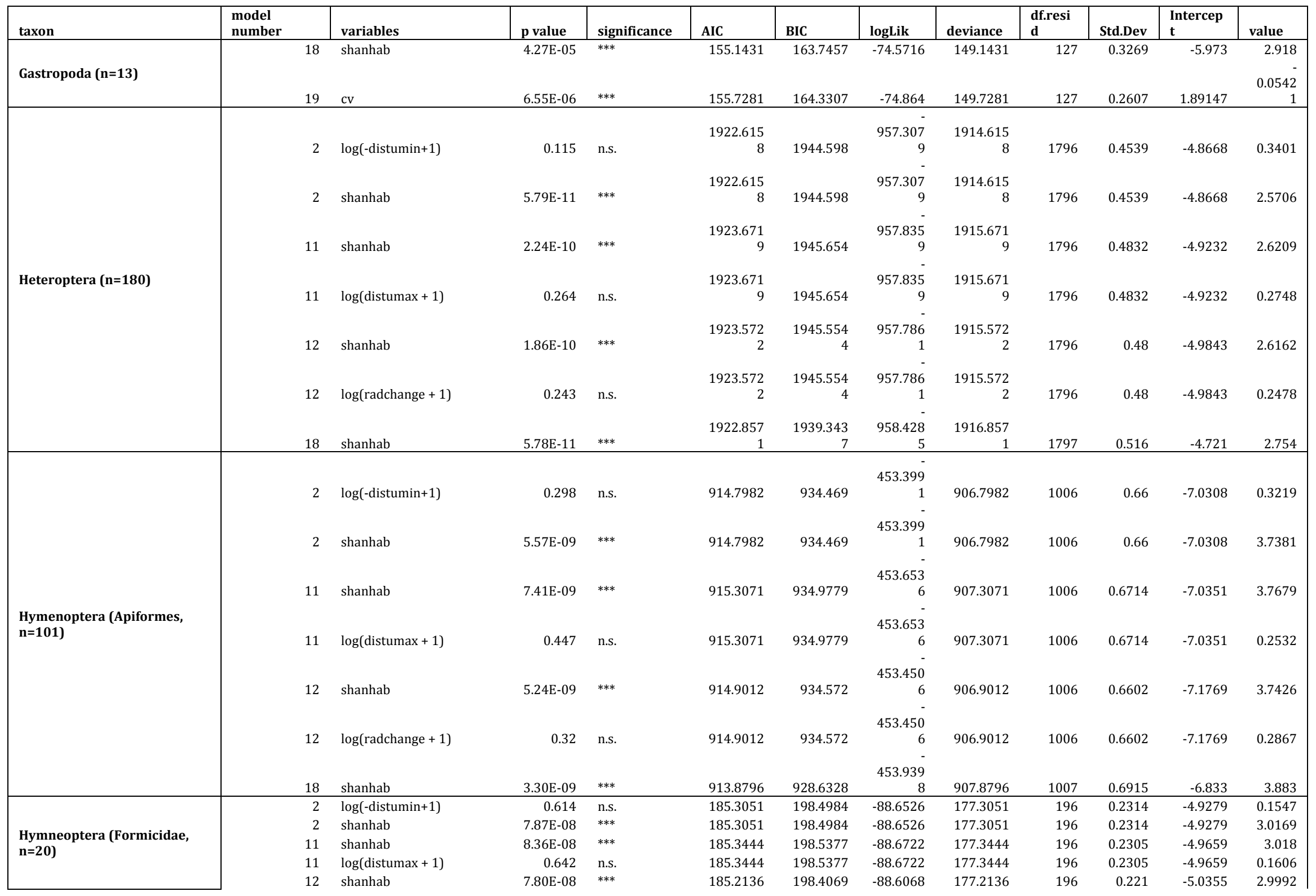




\begin{tabular}{|c|c|c|c|c|c|c|c|c|c|c|c|c|}
\hline taxon & $\begin{array}{l}\text { model } \\
\text { number }\end{array}$ & variables & p value & significance & AIC & BIC & logLik & deviance & $\begin{array}{l}\text { df.resi } \\
\text { d }\end{array}$ & Std.Dev & $\begin{array}{l}\text { Intercep } \\
\mathrm{t}\end{array}$ & value \\
\hline & 12 & $\log ($ radchange +1$)$ & 0.554 & n.s. & 185.2136 & 198.4069 & -88.6068 & 177.2136 & 196 & 0.221 & -5.0355 & 0.1735 \\
\hline & 18 & shanhab & $1.21 \mathrm{E}-08$ & $* * *$ & 183.5592 & 193.4541 & -88.7796 & 177.5592 & 197 & 0.2495 & -4.857 & 3.103 \\
\hline \multirow{8}{*}{$\begin{array}{l}\text { Hymenoptera (Non- } \\
\text { Apiformes, } n=116 \text { ) }\end{array}$} & 2 & $\log ($-distumin +1$)$ & 0.0402 & * & $\begin{array}{r}1148.720 \\
9\end{array}$ & $\begin{array}{r}1168.945 \\
6\end{array}$ & $\begin{array}{r}570.360 \\
4\end{array}$ & $\begin{array}{r}1140.720 \\
9\end{array}$ & 1156 & 0.485 & -6.9587 & 0.4905 \\
\hline & & & & & 1148.720 & 1168.945 & 570.360 & 1140.720 & & & & \\
\hline & $\begin{array}{r}2 \\
11\end{array}$ & $\begin{array}{l}\text { shanhab } \\
\text { shanhab }\end{array}$ & $\begin{array}{l}1.14 \mathrm{E}-11 \\
1.37 \mathrm{E}-10\end{array}$ & ${ }^{* * * *}$ & $\begin{array}{r}9 \\
115029\end{array}$ & $\begin{array}{r}6 \\
1170.515\end{array}$ & $\begin{array}{r}4 \\
-571.145\end{array}$ & $\begin{array}{r}9 \\
1142.29\end{array}$ & 1156 & $\begin{array}{l}0.485 \\
0.534\end{array}$ & $\begin{array}{l}-6.9587 \\
-7.0504\end{array}$ & $\begin{array}{l}3.4405 \\
3.4989\end{array}$ \\
\hline & 11 & $\log ($ distumax +1$)$ & 0.125 & n.s. & 1150.29 & 1170.515 & -571.145 & 1142.29 & 1156 & 0.534 & -7.0504 & 0.4174 \\
\hline & 12 & shanhab & 2785.11 & $* * *$ & 1149.301 & 1169.526 & 570.650 & 1141.301 & 1156 & 0503 & 71097 & 3465 \\
\hline & 12 & logfradchang 1 & 0061 & & 1149.301 & 1169.526 & 570.650 & 1141.301 & 1156 & 0503 & 71097 & 04278 \\
\hline & 14 & $\log ($ racicnange+ + ) & 0.001 & & & & - & & 1150 & & & \\
\hline & 18 & shanhab & $6.11 \mathrm{E}-10$ & $* * *$ & $\begin{array}{r}1150.434 \\
6 \\
\end{array}$ & $\begin{array}{r}1165.603 \\
1 \\
\end{array}$ & $\begin{array}{r}572.217 \\
3 \\
\end{array}$ & $\begin{array}{r}1144.434 \\
6 \\
\end{array}$ & 1157 & 0.6246 & -6.84 & 3.744 \\
\hline \multirow{10}{*}{ Lepidoptera $(n=81)$} & 2 & $\log (-$ distumin+1) & 0.3605 & n.s. & 632.6678 & 651.4559 & $\begin{array}{r}312.333 \\
9\end{array}$ & 624.6678 & 806 & 2.815 & -7.0752 & -0.8586 \\
\hline & 11 & shanhab & 0.0616 & . & 633.2009 & 651.989 & $\begin{array}{r}312.600 \\
5\end{array}$ & 625.009 & 806 & 2.293 & -7.4926 & 3.8407 \\
\hline & 11 & $\log ($ distumax +1$)$ & $6.48 \mathrm{E}-01$ & n.s. & 633.2009 & 651.989 & $\begin{array}{r}312.600 \\
5\end{array}$ & 625.009 & 806 & 2.293 & -7.4926 & -0.4829 \\
\hline & 12 & shanhab & 0.0552 & . & 633.0324 & 651.8205 & $\begin{array}{r}312.516 \\
2\end{array}$ & 6250324 & 806 & 2258 & -7112 & 38617 \\
\hline & 12 & $\log ($ radchange +1$)$ & 5.33E-01 & n.s. & 633.0324 & 651.8205 & $\begin{array}{r}312.516 \\
2\end{array}$ & 625.0324 & 806 & 2.258 & -7.112 & -0.5698 \\
\hline & & & & & & & 312.702 & & & & & \\
\hline & 18 & shanhab & 0.0731 & . & 631.4043 & 645.4955 & $\begin{array}{l}2 \\
-\end{array}$ & 625.4043 & 807 & 2.336 & -8.019 & 3.687 \\
\hline & 19 & $\mathrm{cv}$ & 0.128 & n.s. & 632.5621 & 646.6532 & $\begin{array}{r}313.281 \\
1\end{array}$ & 626.5621 & 807 & 2.389 & 1.52959 & $\begin{array}{r}0.0598 \\
6\end{array}$ \\
\hline & & & & & & & 314.367 & & & & & \\
\hline & 20 & null model & 0.404 & n.s. & 632.7353 & 642.1294 & 6 & 628.7353 & 808 & 2.616 & -0.7047 & - \\
\hline Nematocera $(n=0)$ & - & - & - & - & - & - & - & - & - & - & - & - \\
\hline Odonata $(n=25)$ & $\begin{array}{l}2 \\
2\end{array}$ & $\begin{array}{l}\log (- \text { distumin+1) } \\
\text { shanhab }\end{array}$ & $\begin{array}{r}0.7795 \\
0.00913\end{array}$ & $\begin{array}{l}\text { n.s. } \\
* *\end{array}$ & $\begin{array}{l}241.1566 \\
241.1566\end{array}$ & $\begin{array}{l}255.2424 \\
255.2424\end{array}$ & $\begin{array}{r}116.578 \\
3 \\
-\end{array}$ & $\begin{array}{l}233.1566 \\
233.1566\end{array}$ & $\begin{array}{l}246 \\
246\end{array}$ & $\begin{array}{l}1.587 \\
1.587\end{array}$ & $\begin{array}{l}-8.1075 \\
-8.1075\end{array}$ & $\begin{array}{l}0.2081 \\
4.0448\end{array}$ \\
\hline
\end{tabular}




\begin{tabular}{|c|c|c|c|c|c|c|c|c|c|c|c|c|}
\hline \multirow[t]{10}{*}{ taxon } & $\begin{array}{l}\text { model } \\
\text { number }\end{array}$ & variables & p value & significance & AIC & BIC & logLik & deviance & $\begin{array}{l}\text { df.resi } \\
\text { d }\end{array}$ & Std.Dev & $\begin{array}{l}\text { Intercep } \\
\mathrm{t}\end{array}$ & value \\
\hline & \multirow{2}{*}{\multicolumn{2}{|c|}{ shanhab }} & \multicolumn{10}{|c|}{$\begin{array}{r}116.578 \\
3\end{array}$} \\
\hline & & & & & & & 116.215 & & & & & \\
\hline & \multirow[b]{2}{*}{11} & \multirow[b]{2}{*}{$\log ($ distumax +1$)$} & & & & & \multirow{2}{*}{$\begin{array}{r}116.215 \\
8\end{array}$} & & & & & \\
\hline & & & 0.36682 & n.s. & 240.4316 & 254.5175 & & 232.4316 & 246 & 1.526 & -8.5305 & 0.6906 \\
\hline & 12 & shanhab & 0.0102 & * & 240.8644 & 254.9502 & 116.432 & 232.8644 & 246 & 1.567 & -8.515 & 3.9539 \\
\hline & \multirow{3}{*}{12} & \multirow[b]{2}{*}{$\log ($ radchange +1$)$} & & & & & \multirow{2}{*}{$\begin{array}{r}116.432 \\
2\end{array}$} & & & & & \\
\hline & & & 0.5433 & n.s. & 240.8644 & 254.9502 & & 232.8644 & 246 & 1.567 & -8.515 & 0.4165 \\
\hline & & & & & & & \multirow{2}{*}{$\begin{array}{r}116.617 \\
7 \\
\end{array}$} & & & & & \\
\hline & 18 & shanhab & 0.00712 & $* *$ & 239.2355 & 249.7999 & & 233.2355 & 247 & 1.587 & -7.932 & 4.114 \\
\hline Saltatoria $(n=9)$ & 18 & shanhab & $1.19 \mathrm{E}-06$ & $* * *$ & 75.2274 & 82.7268 & -34.6137 & 69.2274 & 87 & 0 & -6.753 & 4.086 \\
\hline \multirow{6}{*}{ Siphonaptera $(\mathrm{n}=\mathbf{8})$} & 2 & $\log (-$ distumin+1) & 0.2296 & n.s. & 100.5501 & 110.0782 & -46.275 & 92.5501 & 76 & 0.842 & -5.3232 & 0.6542 \\
\hline & 2 & shanhab & $3.32 \mathrm{E}-02$ & * & 100.5501 & 110.0782 & -46.275 & 92.5501 & 76 & 0.842 & -5.3232 & 2.3331 \\
\hline & 11 & shanhab & 0.0318 & * & 98.7365 & 108.2646 & -45.3683 & 90.7365 & 76 & 0.6963 & -5.626 & 2.14 \\
\hline & 11 & $\log (\operatorname{distumax}+1)$ & 0.07151 & . & 98.7365 & 108.2646 & -45.3683 & 90.7365 & 76 & 0.6963 & -5.626 & 1.003 \\
\hline & 12 & shanhab & 0.0319 & * & 99.5109 & 109.039 & -45.7555 & 91.5109 & 75 & 0.7667 & -5.8448 & 2.2531 \\
\hline & 18 & shanhab & $2.00 \mathrm{E}-16$ & $* * *$ & 100.0229 & 107.169 & -47.0115 & 94.0229 & 77 & 0.953 & -4.844 & 2.589 \\
\hline \multirow{11}{*}{ Symphyta (n=119) } & 2 & $\log ($-distumin+1) & 0.0576 & . & 1088.654 & 1108.981 & -540.327 & 1080.654 & 1186 & 0.1193 & -8.5189 & 0.2377 \\
\hline & 2 & shanhab & $2.00 \mathrm{E}-16$ & $* * *$ & 1088.654 & 1108.981 & -540.327 & 1080.654 & 1186 & 0.1193 & -8.5189 & 4.3011 \\
\hline & \multirow[b]{2}{*}{11} & & & & 1089.920 & & 540.960 & 1081.920 & & & & \\
\hline & & shanhab & $2.00 \mathrm{E}-16$ & *** & 2 & 1110.247 & 1 & 2 & 1186 & 0.1543 & -8.4377 & 4.271 \\
\hline & \multirow[b]{2}{*}{11} & & & & 1089.920 & & 540.960 & 1081.920 & & & & \\
\hline & & $\log ($ distumax +1$)$ & 0.146 & n.s. & 2 & 1110.247 & 1 & 2 & 1186 & 0.1543 & -8.4377 & 0.1989 \\
\hline & 12 & shanhab & $200 \mathrm{~F}-16$ & $* * *$ & 1089.298 & 1109.625 & 540.649 & 1081.298 & 1186 & 01371 & -85758 & 4.2908 \\
\hline & \multirow[b]{2}{*}{12} & \multirow[b]{2}{*}{$\log ($ radchange +1$)$} & \multirow[b]{2}{*}{0.091} & \multirow[b]{2}{*}{. } & 1089.298 & 1109.625 & $540.649^{-}$ & 1081.298 & & & & \\
\hline & & & & & 6 & 4 & 3 & 6 & 1186 & 0.1371 & -8.5758 & 0.2001 \\
\hline & & & & & 1089.901 & 1105.146 & 541.950 & 1083.901 & & & & \\
\hline & 18 & shanhab & $2.00 \mathrm{E}-16$ & $* * *$ & 3 & 4 & 6 & 3 & 1187 & 0.2 & -8.216 & 4.329 \\
\hline \multirow{5}{*}{ Trichoptera $(n=5)$} & 11 & shanhab & 0.0668 & . & 66.8603 & 74.5084 & -29.4301 & 58.8603 & 46 & 0.9328 & -5.9981 & 2.5526 \\
\hline & 11 & $\log (\operatorname{distumax}+1)$ & $5.24 \mathrm{E}-01$ & n.s. & 66.8603 & 74.5084 & -29.4301 & 58.8603 & 46 & 0.9328 & -5.9981 & 0.4147 \\
\hline & & & & & & & & & & & & 0.0830 \\
\hline & 17 & area & 5.73E-02 & . & 66.2925 & 72.0286 & -30.1463 & 60.2925 & 47 & 0.9671 & -1.51821 & \\
\hline & 18 & shanhab & 0.0526 & & 65.269 & 71.005 & -29.6345 & 59.269 & 47 & 0.9781 & -5.642 & 2.727 \\
\hline
\end{tabular}




\section{Table S2 Taxon identity}

Merged taxon terminology contained different taxa. Where all recent sub groups could be used during analysis, the official taxon name kept used.

\begin{tabular}{|c|c|c|}
\hline \multirow{12}{*}{ Plants } & $\operatorname{taxon}$ & families \\
\hline & \multirow[t]{5}{*}{ Fern } & Woodsiaceae \\
\hline & & Ophioglossaceae \\
\hline & & Dryopteridaceae \\
\hline & & Osmundaceae \\
\hline & & Polypodiaceae \\
\hline & \multirow[t]{6}{*}{ Grass } & Acoraceae \\
\hline & & Cyperaceae \\
\hline & & Juncaeae \\
\hline & & Juncaginaceae \\
\hline & & Poaceae \\
\hline & & Typhaceae \\
\hline
\end{tabular}

\begin{tabular}{|l|}
\hline Herbs Alismataceae \\
Amaranthaceae \\
Amaryllidaceae \\
Apiaceae \\
Apocynaceae \\
Aquifoliaceae \\
Araceae \\
Araliaceae \\
Asparagaceae \\
Asteraceae \\
Balsaminaceae \\
Boraginaceae \\
Brassicaceae \\
Campanulaceae \\
Cannabaceae \\
Caprifoliaceae \\
Caryophyllaceae \\
Celastraceae \\
Convolvulaceae \\
Crassulaceae \\
Droseraceae \\
Equisetaceae \\
Ericaceae \\
Euphorbiaceae \\
Fabaceae \\
Gentianaceae \\
Geraniaceae \\
Haloragaceae \\
\\
\hline
\end{tabular}


Hederaceae

Hypericaceae

Iridaceae

Lamiaceae

Linaceae

Lycopodiaceae

Lythraceae

Malvaceae

Montiaceae

Nymphaeceae

Onagraceae

Orchidaceae

Orobanchaceae

Oxalidaceae

Papaveraceae

Plantaginaceae

Plumbaginaceae

Polygalaceae

Potamogetonaceae

Primulaceae

Ranunculaceae

Resedaceae

Rosaceae

Rubiaceae

Ruppiaceae

Scrophulariaceae

Solanaceae

Urticaceae

Violaceae

\begin{tabular}{|c|c|}
\hline Shrubs & $\begin{array}{l}\text { Adoxaceae } \\
\text { Betulaceae } \\
\text { Elaeagnaceae } \\
\text { Ericaceae } \\
\text { Fabaceae } \\
\text { Grossulariaceae } \\
\text { Oleaceae } \\
\text { Rhamnaceae } \\
\text { Rosaceae } \\
\text { Vitaceae }\end{array}$ \\
\hline
\end{tabular}

Trees

Betulaceae

Elaeagnaceae

Fabaceae

Fagaceae 
Pinaceae

Rosaceae

Salicaceae

Sapindaceae

Ulmaceae

\begin{tabular}{|c|c|c|}
\hline \multirow[t]{2}{*}{ Vertebrata } & Mammalia & $\begin{array}{l}\text { Cervidae } \\
\text { Cricetidae } \\
\text { Erinaceidae } \\
\text { Leporidae } \\
\text { Muridae } \\
\text { Soricidae }\end{array}$ \\
\hline & Osteichthyes & $\begin{array}{l}\text { Anguillidae } \\
\text { Gasterosteidae } \\
\text { Pleuronectidae }\end{array}$ \\
\hline
\end{tabular}

\section{Invertebrata}

Brachycera

Agromyzidae

Chloropidae

Conopidae

Dolichopodidae

Drosophilidae

Empididae

Helcomyzidae

Hybotidae

Lauxaniidae

Lonchopteridae

Opomyzidae

Rhagionidae

Sciomyzidae

Sepsidae

Stratiomyidae

Syrphidae

Tephritidae

Therevidae

Coleoptera (other)

Alleculidae

Anobiidae

Anthiciidae

Bruchidae

Byrrhidae

Byturidae

Cantharidae 
Cholevidae

Clambidae

Coccinelidae

Cryptophagidae

Dermestidae

Dryopidae

Elateridae

Geotrupidae

Heteroceridae

Histeridae

Kateretidae

Lagriidae

Lathridiidae

Leiodidae

Malachiidae

Meloidae

Melyridae

Mycetophagidae

Nitidulidae

Oedemeridae

Phalacridae

Pselaphidae

Ptiliidae

Scarabaeidae

Scirtidae

Scolytidae

Scraptiidae

Scydmaenidae

Silphidae

Silvanidae

Tenebrionidae

Trogidae

\begin{tabular}{|ll|}
\hline Coleoptera (phytophagous) & Apionidae \\
& Cerambycidae \\
& Chrysomelidae \\
& Curcolionidae \\
& Rhynchitidae \\
\hline
\end{tabular}

$\begin{array}{ll}\text { Crustaceae } & \text { Cladocera } \\ \text { Ostracoda }\end{array}$

Gastropoda

Agriolimacidae

Helicidae

Hydrobiidae 
Lymnaeidae

Planorbidae

Tateidae

\begin{tabular}{|ll|}
\hline Hymenoptera (Non-Apiformes) & Chrysididae \\
& Crabronidae \\
& Pompilidae \\
Sapygidae \\
Sphecidae \\
Tiphiidae \\
Vespidae \\
\hline
\end{tabular}

Lepidoptera Cossidae

Erebidae

Geometridae

Lasiocampidae

Lycaenidae

Noctuidae

Notodontidae

Nymphalidae

Pieridae

Sphingidae

Zygaenidae

\begin{tabular}{|ll|}
\hline Symphyta & Argidae \\
& Cephidae \\
& Tenthredinidae \\
& Xiphydriidae \\
\hline Trichoptera & \\
\hline
\end{tabular}




\section{CHAPTER 3:}

Colonization and taxon shift in an experimental island system

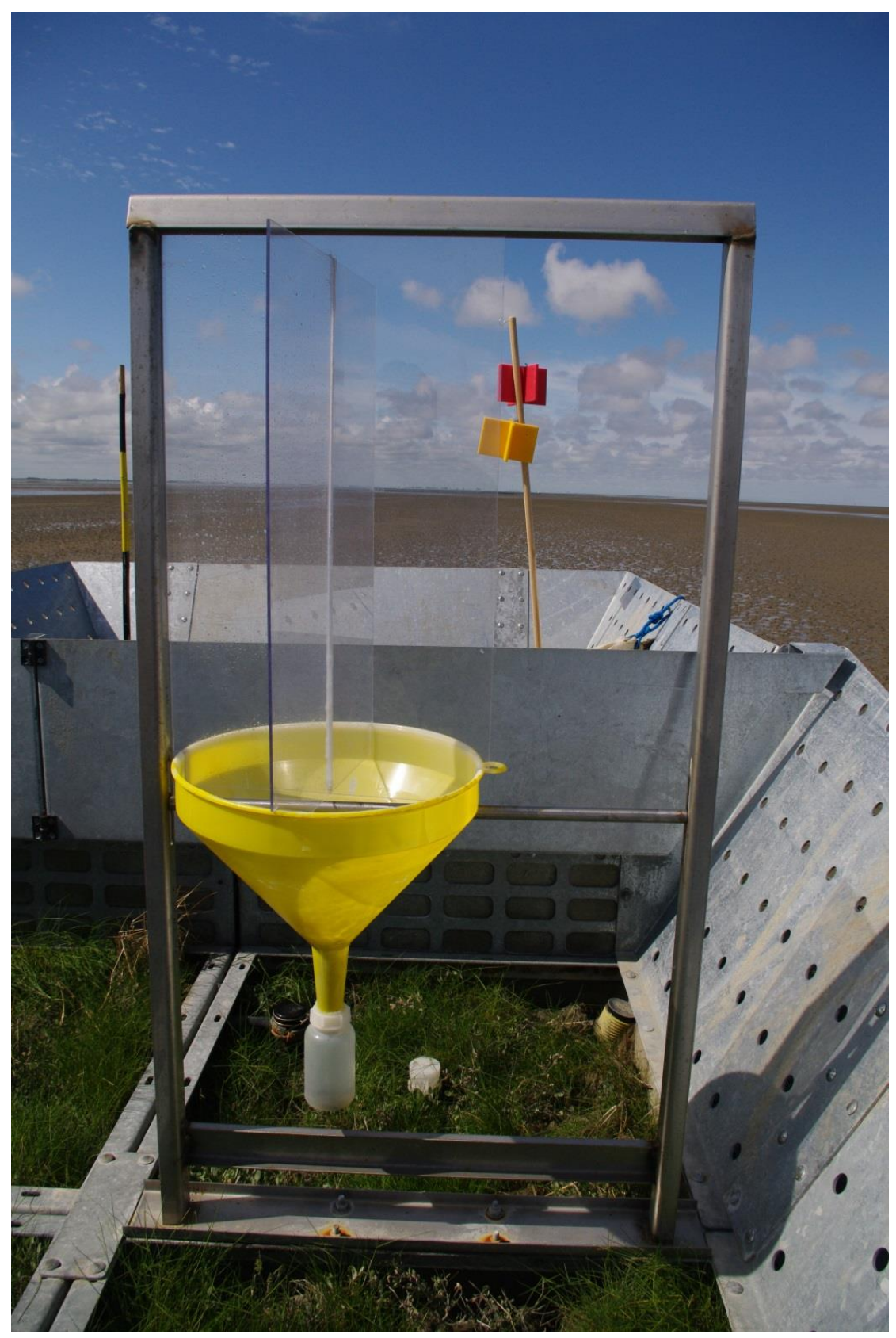

Hagen Andert, Christoph Scherber, Teja Tscharntke 


\begin{abstract}
Understanding patterns of island colonization is still a major focus in ecology and conservation, while colonization of standardized, experimental islands in the sea has been rarely shown due to logistic difficulties. Here, we set up six planted (with saltmarsh vegetation) and six non-planted experimental islands at a distance of c. $500 \mathrm{~m}$ south of the North Sea island of Spiekeroog (Germany) to study colonization dynamics of mobile arthropods in a standardized way. We sampled c. 40,000 arthropods during one season (May-September) across eight taxa using storm-proof window, funnel and sticky traps, placed on each of the 12 islands and on six natural salt marsh plots of Spiekeroog. Seven of eight taxa (Aphididae, Araneae, Brachycera, Coleoptera, Hymenoptera, Nematocera and Thysanoptera, but not Auchenorrhyncha) had lower abundances on the experimental islands compared with the Spiekeroog control plots, the presumable source area of the arthropods colonizing the experimental islands. Taxon differed in time of maximal colonization (interaction of island abundance with month of sample) in seven of eight taxa (Araneae excluded). In contrast to expectations, colonization of planted vs non-planted islands did not show major differences: In five taxa, the nonplanted islands showed significantly lower abundance than the Spiekeroog control plots, and in four taxa the planted islands. Our results showed that island colonization by these mobile arthropod taxa went quickly already in the first season after island establishment, while arthropod groups appeared to discriminate between planted and non-planted islands in contrasting ways.
\end{abstract}

Keywords: artificial islands, barrier islands, BEFmate, colonization, insects, island biogeography, sea level rise 


\section{Introduction}

Understanding patterns of island colonization is still a major focus in ecology and conservation, while colonization of standardized, experimental islands in the sea has rarely been investigated due to logistic difficulties. Only a few experiments pursue the goal to observe both extinction and invasion rates of organisms on newly establishing island communities (Losos, Warheitt, \& Schoener, 1997; Rejmánek et al., 2002; Simberloff \& Wilson, 1969, 1970). Thereby, the ratio of invasion and extinction is one of the main drivers of colonization success in combination with island size (MacArthur \& Wilson, 1967). Small or strongly isolated islands are less colonized than larger or connected ones (ibidem). So far, colonization processes have been investigated mostly on oceanic islands and cover a worldwide scale (Weigelt et al., 2013). Beside oceanic islands, other types are categorized into continental shelf islands, habitat islands and non-marine-islands (Whittaker 1998). We conducted our experiment in a continental shelf island system, which has no mainland core and is only built in the offshore region by sedimentation and erosion processes (Pott and Peters 2005, Niedringhaus et al. 2008): the East Frisian Islands, a so called barrier island system. To assess early stages of barrier island formation and colonization processes, Balke et al. (2017) designed an artificial barrier island system. Here, we used 12 artificial islands to experimentally disentangle effects of planted vs. non-planted islands (with or without salt-marsh vegetation planted). We measure seasonal abundance of different arthropod taxa, using window, funnel and sticky traps, and compare results with samples from six natural salt marsh sites in Spiekeroog.

We hypothesize that

(1) Arthropod taxa are much less abundant on the experimental islands than on the natural sites of Spiekeroog, while taxon-specific differences occur.

(2) Colonization of planted experimental islands is much higher than that of non-planted islands. 


\section{Material and Methods}

\section{Study area}

The experiment was located in the Southern part of the island of Spiekeroog (Germany, $53^{\circ} 45^{\prime} 31^{\prime \prime} \mathrm{N}, 7^{\circ} 43^{\prime} 30^{\prime \prime} \mathrm{E}$ ), Wadden Sea World Heritage. Spiekeroog is one of eleven East Frisian barrier islands, which were formed by sedimentation- and erosion processes during the last 1,200 years (Niedringhaus et al., 2009). The Southern edge of Spiekeroog is dominated by three habitat zones: (1) a pioneer zone, exclusively under marine influence; (2) lower salt marshes under marine and terrestrial influence, and (3) the terrestrial upper salt marshes.

\section{Experimental islands and sampling design}

In September 2014, N=12 experimental islands were constructed in the North Sea (syn. Wadden Sea) $500 \mathrm{~m}$ south of Spiekeroog within the BEFmate (Biodiversity - Ecosystem Functioning across marine and terrestrial ecosystems, https://www.icbm.de/verbundprojekte/befmate/ ) project. Further details about the establishment process of artificial islands in the Wadden Sea and the complete experimental design can be found in Balke et al (2017). In addition to the artificial experimental islands, corresponding control plots were established on Spiekeroog. Experimental islands were either (i) non-planted experimental islands filled with Wadden Sea sediment or (ii) planted artificial islands with transplanted lower salt marsh vegetation sods. Under different water and drought stress factors, plant communities of the lower salt marsh are expected to develop into a more marine or terrestrial direction in the course of succession.

\section{Arthropod sampling}

A storm- and flooding-proof combined trap consisting of a cross window trap and a funnel trap was installed in the centre of each artificial island in April 2015 for five months (May to September 2015). We used saturated $\mathrm{NaCl}$ solution as a trapping liquid. Due to high wind energy and salt water influence, combined traps were modified from the original building plans of the Swiss Federal Institute for Forest, Snow and Landscape Research (WSL). For further construction information see S1. Additionally, in one upper corner of each artificial island, a crossed sticky trap with red and yellow colour was installed and coated with water-resistant Tangle trap glue (Andermatt Biocontrol, Switzerland). Traps were emptied every month between April and September 2015 
following requirements by the National Park Wadden Sea World Heritage. Overall, we collected 40,093 individuals across 20 taxa (Acari, Aphalaridae, Aphididae, Araneae, Auchenorrhyncha, Brachycera, Coleoptera, Collembola, Crustacea, Gastropoda, Heteroptera, Hymenoptera, Lepidoptera, Nematocera, Neuroptera, Psocoptera, Psyllidae, Saltatoria, Thysanoptera and Trichoptera). Arthropod taxa were identified to at least order level using a stereo microscope and taxonomic keys (Dunger \& Fiedler, 1999; Bährmann, 2008; Schäfer 2017).

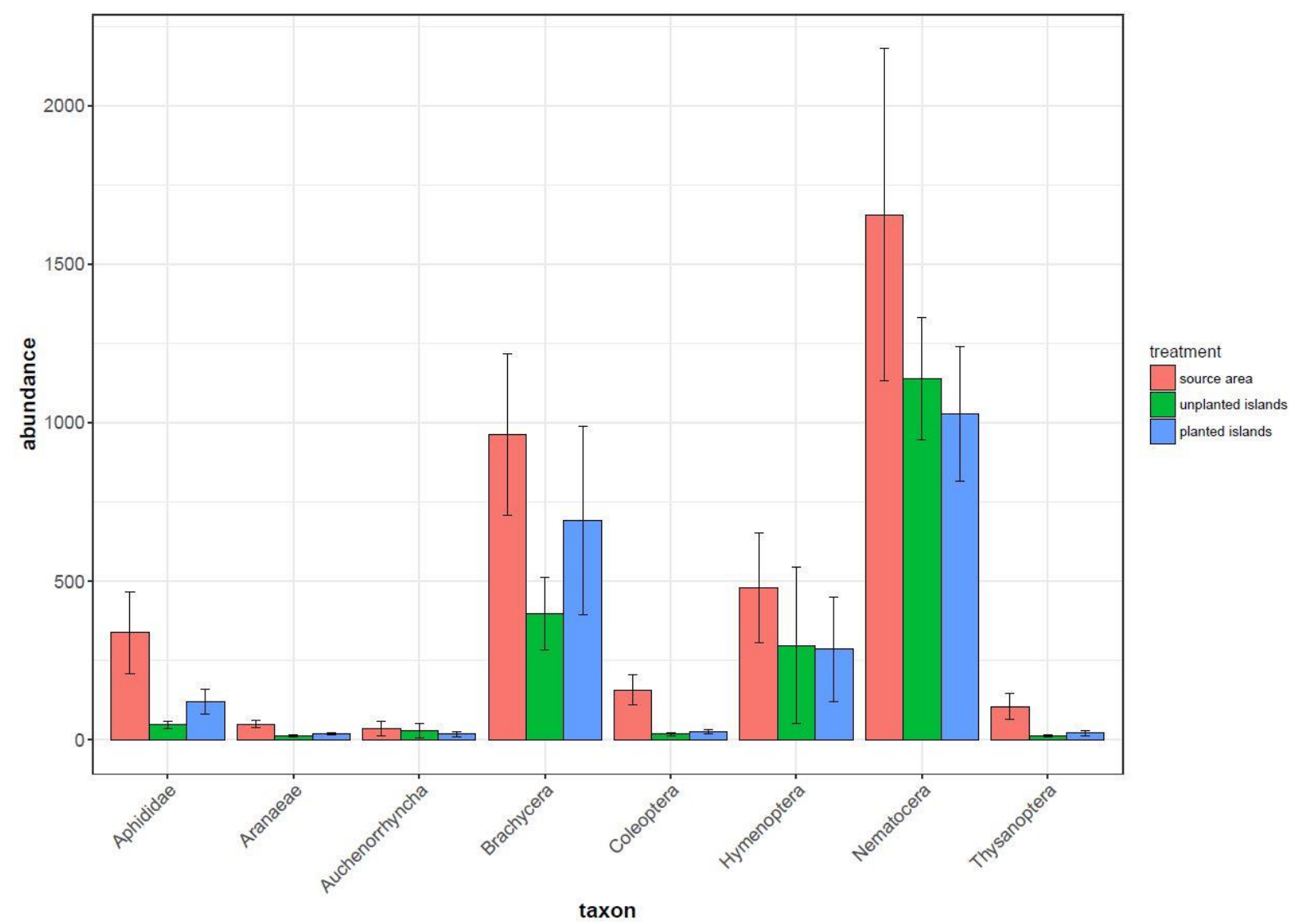

Figure 1 Total abundance of all taxa over the three experimental treatments. Ctrl stands for Control plots, EI-non-planted for non-planted island and EI-planted for non-planted and planted island treatment. In aphids, flies, Hymenoptera and Nematocera a strong decline in taxon abundance can be observed comparing control and both island treatments. Highest taxon abundance could be found in Nematocera, followed by Brachycera and Hymenoptera. 


\section{Statistical Analyses}

Data were analyzed using R 3.3.2. (R Development Core Team 2016). Total abundances of all taxa from both trap types were aggregated by collection month, habitat zone, plot type (experimental or control), vegetation type (planted or non-planted experimental islands) and experimental island identity. Out of 20 total taxa, 39,653 individuals of the eight most abundant taxa were used for further analysis (Aphididae, Araneae, Auchenorrhyncha, Brachycera, Coleoptera, Hymenoptera, Nematocera and Thysanoptera). We employed a log transformation for count data. Initial models contained a manyglm (negative binomial) approach with taxon abundances as response variable and month, and treatment (planted vs. non-planted islands and control) as explanatory variables. They were simplified based on relative abundances in a linear mixed model approach. The final model contained log transformed relative abundances to fit a linear mixed model. 


\section{Aphididae}

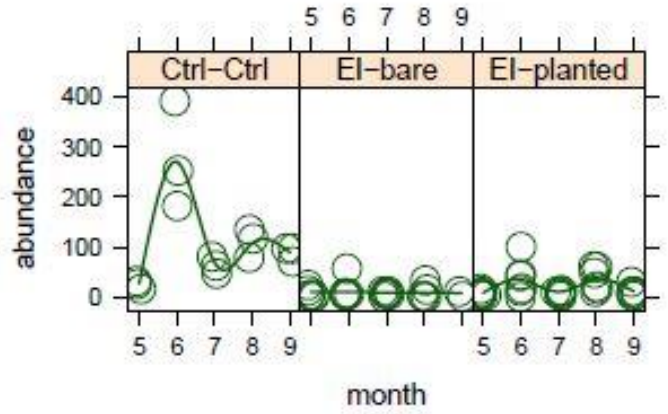

Auchenorrhyncha

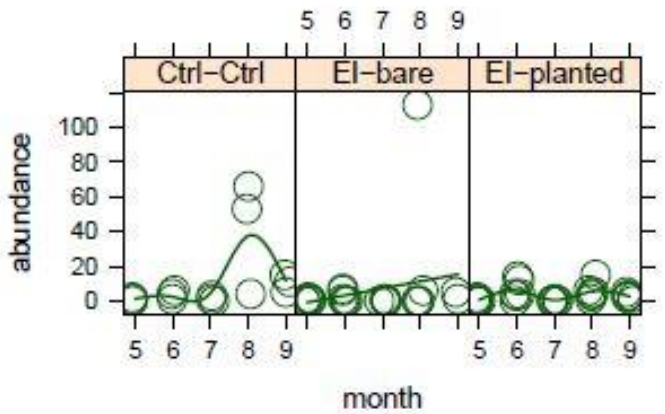

Coleoptera

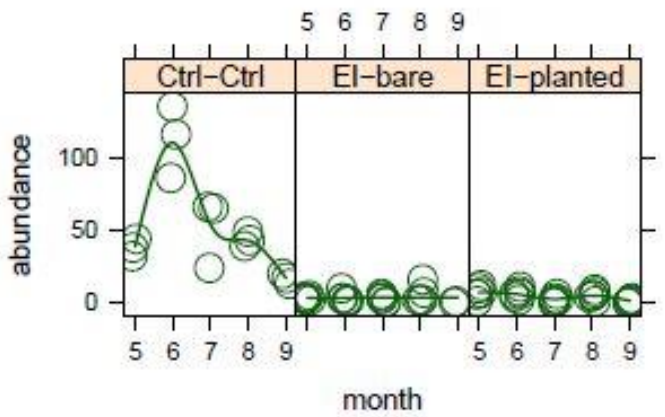

Nematocera

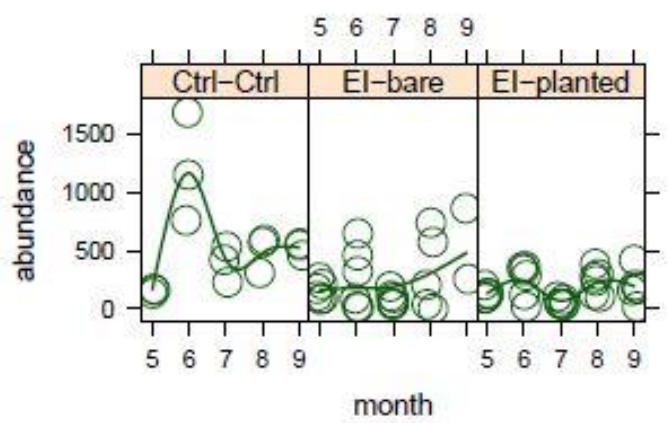

Aranaeae

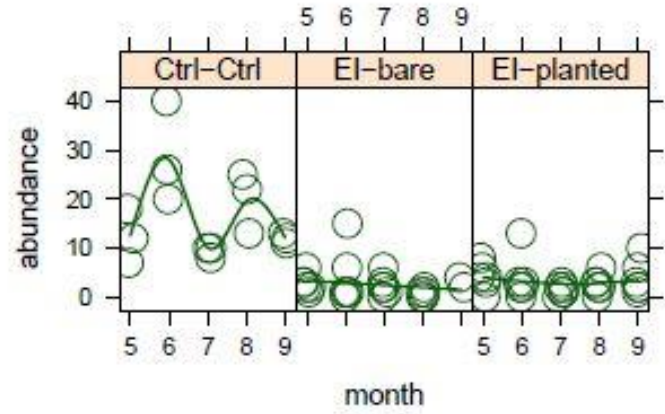

Brachycera

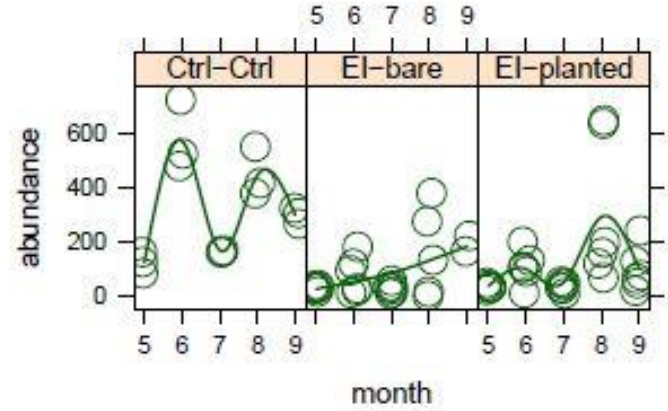

Hymenoptera

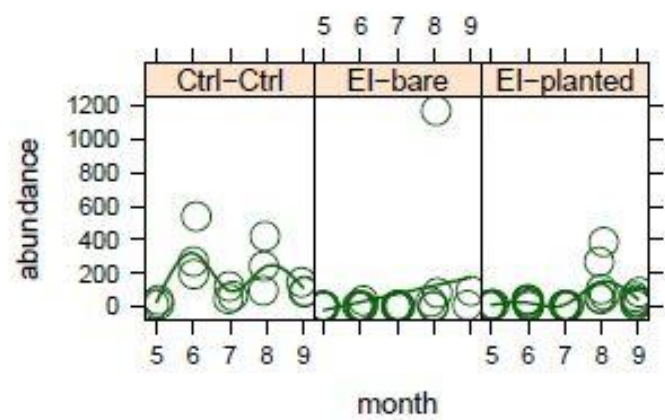

Thysenoptera

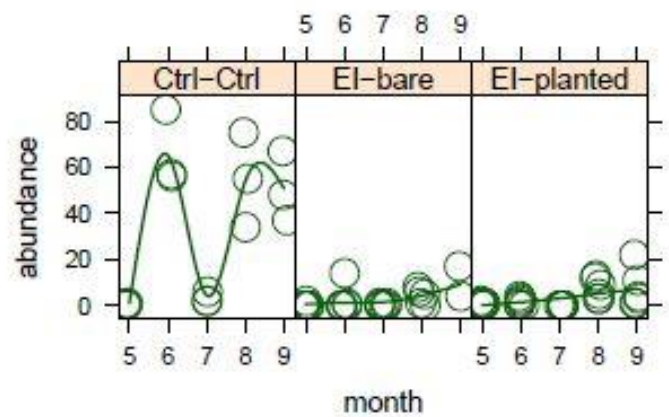

Figure 2 Absolute taxon abundance of all taxa over time. Over time, Aphididae, Aranaeae, Brachycera, Hymenoptera and Thysanoptera show an abundance peak during June and August. In comparison, Coleoptera and Nematocera have their only highest abundance peak in June, whereas Auchenorrhyncha show highest abundance during August. In all taxa, the two- or one-peaked abundance regimes are collapsed in experimental treatments. 


\section{Results}

Out of 20 caught taxa, eight taxa (Aphididae, Araneae, Auchenorrhyncha, Brachycera, Coleoptera, Hymenoptera, Nematocera and Thysanoptera) were most abundant (Figure 1, Figure 2). Four taxa were the most dominant ones (Table 1): Nematocera $\left(\mathrm{N}_{\mathrm{Ctrl}}=8278\right.$ specimens, $\left.\mathrm{N}_{\text {islands }}=10780\right)$, Brachycera $\left(\mathrm{N}_{\mathrm{Ctrl}}=4812, \mathrm{~N}_{\text {islands }}=5439\right)$, Hymenoptera $\left(\mathrm{N}_{\text {Ctrl }}=2393, \mathrm{~N}_{\text {islands }}=2918\right)$ and Aphididae $\left(\mathrm{N}_{\text {Ctrl }}=1688, \mathrm{~N}_{\text {islands }}=836\right)$. Except in Auchenorrhyncha, in all taxa, the source area plots contained a higher number of individuals than the experimental islands.

Table 1 Abundance of caught invertebrates on all experimental treatments. During our experiment, we caught around 40,000 individuals from 20 identified taxa on six non-planted (EI-non-planted) and six planted (EI-planted) experimental islands $500 \mathrm{~m}$ south of Spiekeroog island. Control plots are divided into naturally occurring habitat zonation: Pioneer zone (Ctrl-Pio), Lower salt marsh (Ctrl-Low) and Upper salt marsh (Upp). Bold taxa display the most abundant taxa during one year of observation, where half of these taxa where more present on experimental islands (Aphididae, Hymenoptera, Brachycera and Nematocera) than others (Araneae, Auchenorrhyncha, Coleoptera and Thysanoptera) indicating dispersal limitation in latter taxa.

\begin{tabular}{l|r|r|r|}
\multicolumn{1}{l}{ Treatment } \\
Taxon & El-planted & El-non planted & Ctrl \\
Acari & 17 & 4 & \\
Aphalaridae & 0 & 1 & 31 \\
Aphididae & 598 & 238 & 2 \\
Aranaeae & 97 & 65 & 1688 \\
Auchenorrhyncha & 90 & 144 & 247 \\
Brachycera & 3450 & 1989 & 172 \\
Coleoptera & 131 & 87 & 4812 \\
Collembola & 0 & 787 \\
Crustacea & 1 & 1 & 0 \\
Gastropoda & 8 & 0 & 19 \\
Heteroptera & 24 & 4 & 196 \\
Hymenoptera & 1429 & 5 & 19 \\
indet & 195 & 1489 & 2393 \\
larvae & 10 & 115 & 229 \\
Lepidoptera & 53 & 3 & 12 \\
Nematocera & 5134 & 8 & 19 \\
Neuroptera & 3 & 5646 & 8278 \\
Psocoptera & 1 & 1 & 12 \\
Psylidae & 0 & 0 & 0 \\
& & 0 & 1
\end{tabular}




\begin{tabular}{l|l|r|r|}
\multicolumn{5}{c}{ Treatment } \\
\cline { 2 - 5 } Taxon & El-planted & El-non planted & Ctrl \\
Saltatoria & 2 & 0 & \\
Thysanoptera & 103 & 60 & 526 \\
Trichoptera & 1 & 0 & 0 \\
total & 11347 & 9860 & 19451 \\
\hline
\end{tabular}

In our model, both month (test stat=1.3780, num $\mathrm{Df}=24$, den $\mathrm{Df}=159, \mathrm{p}<0.001$ ) and experimental treatment (test stat=1.1422, num $\mathrm{Df}=16$, den $\mathrm{Df}=104$ ) explained the relative abundance of pooled taxa (MANOVA, Pillai) best.

Table 2 Results of the best fitting model for all taxa regarding the parameters month, experimental treatment and the interaction-term of both. In the linear model, the experimental treatment has the largest impact on taxa occurrence on our plots. The F-value is much higher for the parameter 'treatment', followed by the seasonal aspect 'month'. The interaction term of both parameters is statistically worse as there is a declining effect in statistical power.

\begin{tabular}{|l|l|l|l|l|l|l|l|}
\hline variable & Df & Num Df & Den Df & $\begin{array}{l}\text { test } \\
\text { stat }\end{array}$ & $\begin{array}{l}\mathbf{F} \\
\text { value }\end{array}$ & $\mathbf{p}$ & significance \\
\hline month & 3 & 24 & 159 & 1.378 & 5.628 & $5.94 \mathrm{E}-12$ & $* * *$ \\
\hline treatment & 2 & 16 & 104 & 1.1422 & 8.6557 & $5.70 \mathrm{E}-13$ & $* * *$ \\
\hline month:treatment & 6 & 48 & 336 & 1.8397 & 3.0953 & $1.21 \mathrm{E}-09$ & $* * *$ \\
\hline
\end{tabular}

The occurrence of taxa is additionally explained by the interaction term of month and treatment $(F=3.0953$, num $D f=48$, den $D f=336, p<0.01)$, but with a lower $F$-value (Table 2).

The abundance of seven taxa exhibited less abundance on experimental islands than on source area plots (Araneae, Coleoptera, Hymenoptera, Brachycera, Nematocera, Thysanoptera, Aphididae). Occurrence of seven taxa was affected by treatment (Aphididae: $\mathrm{df}=2, \mathrm{~F}=44.42, \mathrm{p}<0.001$, Araneae: $\mathrm{df}=2, \mathrm{~F}=52.09, \mathrm{p}<0.001$, Brachycera: $\mathrm{df}=2$, $\mathrm{F}=17.44, \mathrm{p}<0.001$, Coleoptera: $\mathrm{df}=2, \mathrm{~F}=185.29, \mathrm{p}<0.001$, Hymenoptera: $\mathrm{df}=2, \mathrm{~F}=3.95$, $\mathrm{p}=0.025$, Nematocera: $\mathrm{df}=2, \mathrm{~F}=16.60, \mathrm{p}<0.001$ and Thysanoptera: $\mathrm{df}=2, \mathrm{~F}=35.33$, $\mathrm{p}<0.001$, Table 3). For seven taxa month affected taxon occurrence (Aphididae: $\mathrm{df}=3$, $\mathrm{F}=3.63, \mathrm{p}=0.018$, Auchenorrhyncha: $\mathrm{df}=3, \mathrm{~F}=2.79, \mathrm{p}=0.05$, Brachycera: $\mathrm{df}=3, \mathrm{~F}=3.99$, $\mathrm{p}=0.012$, Coleoptera: $\mathrm{df}=3, \mathrm{~F}=7.04, \mathrm{p}<0.001$, Hymenoptera: $\mathrm{df}=3, \mathrm{~F}=2.64, \mathrm{p}=0.058$, Nematocera: $\mathrm{df}=3, \mathrm{~F}=3.04, \mathrm{p}=0.036$ and Thysanoptera: $\mathrm{df}=3, \mathrm{~F}=5.95, \mathrm{p}=0.001$ ). The interaction of both treatment and month displayed an effect on Aphididae $(\mathrm{df}=6, \mathrm{~F}=4.71$, 
$\mathrm{p}=0.001)$, Coleoptera $(\mathrm{df}=6, \mathrm{~F}=14.85, \mathrm{p}<0.001)$, Nematocera $(\mathrm{df}=6, \mathrm{~F}=3.68, \mathrm{p}=0.004)$ and Thysanoptera $(\mathrm{df}=6, \mathrm{~F}=2.72, \mathrm{p}=0.021)$.

Our modelled prediction of taxon occurrence displayed seasonal variation in Spiekeroog salt marsh plots (Figure 3a), which is more distinct and shows stronger taxon-specific differences than on the experimental islands. In planted islands, only Brachycera shows a slight population increase in August (Figure 3b), whereas on non-planted experimental plots, no seasonality of former occurrence fluctuations from the source area visible anymore (Figure $3 \mathrm{c}$ ).

Table 3 ANOVA results of the best fitting model summary for each taxon with detailed parameter effects. In researched taxa, experimental treatment had a highly significant effect in 6 taxa, whereas month displayed high significance in Coleoptea and Thysanoptera only. Three taxa were influenced by the additional interaction term.

\begin{tabular}{|c|c|c|c|c|c|}
\hline Taxon & Variable & Df & $\mathbf{F}$ & $\mathbf{P}$ & Significance \\
\hline \multirow[t]{3}{*}{ Aphididae } & treatment & 2.000 & 44.419 & 0.000 & $* * *$ \\
\hline & month & 3.000 & 3.625 & 0.018 & $*$ \\
\hline & month:treatment & 6.000 & 4.712 & 0.001 & $* * *$ \\
\hline \multirow[t]{3}{*}{ Araneae } & treatment & 2.000 & 52.086 & 0.000 & $* * *$ \\
\hline & month & 3.000 & 1.238 & 0.304 & n.s. \\
\hline & month:treatment & 6.000 & 0.875 & 0.519 & n.s. \\
\hline \multirow[t]{3}{*}{ Auchenorrhyncha } & treatment & 2.000 & 1.790 & 0.176 & n.s. \\
\hline & month & 3.000 & 2.791 & 0.048 & $*$ \\
\hline & month:treatment & 6.000 & 1.252 & 0.294 & n.s. \\
\hline \multirow[t]{3}{*}{ Brachycera } & treatment & 2.000 & 17.440 & 0.000 & $* * *$ \\
\hline & month & 3.000 & 3.987 & 0.012 & $*$ \\
\hline & month:treatment & 6.000 & 1.486 & 0.199 & n.s. \\
\hline \multirow[t]{3}{*}{ Coleoptera } & treatment & 2.000 & 185.285 & 0.000 & $* * *$ \\
\hline & month & 3.000 & 7.041 & 0.000 & $* * *$ \\
\hline & month:treatment & 6.000 & 14.846 & 0.000 & $* * *$ \\
\hline \multirow[t]{3}{*}{ Hymenoptera } & treatment & 2.000 & 3.946 & 0.025 & $*$ \\
\hline & month & 3.000 & 2.636 & 0.058 & . \\
\hline & month:treatment & 6.000 & 0.898 & 0.503 & n.s. \\
\hline \multirow[t]{3}{*}{ Nematocera } & treatment & 2.000 & 16.597 & 0.000 & $* * *$ \\
\hline & month & 3.000 & 3.042 & 0.036 & $*$ \\
\hline & month:treatment & 6.000 & 3.684 & 0.004 & $* *$ \\
\hline \multirow[t]{3}{*}{ Thysanoptera } & treatment & 2.000 & 35.325 & 0.000 & $* * *$ \\
\hline & month & 3.000 & 5.946 & 0.001 & $* *$ \\
\hline & month:treatment & 6.000 & 2.721 & 0.021 & $*$ \\
\hline
\end{tabular}




\section{Discussion}

In our laborious study with planted and non-planted experimental islands, we found that our experimental treatment had an important impact on taxon occurrence in seven out of eight investigated taxa. Additionally, the impact of month was less significant in explaining variation of abundance, but still influenced seven of them. The interaction of treatment and month displayed an effect on only four taxa.

a)

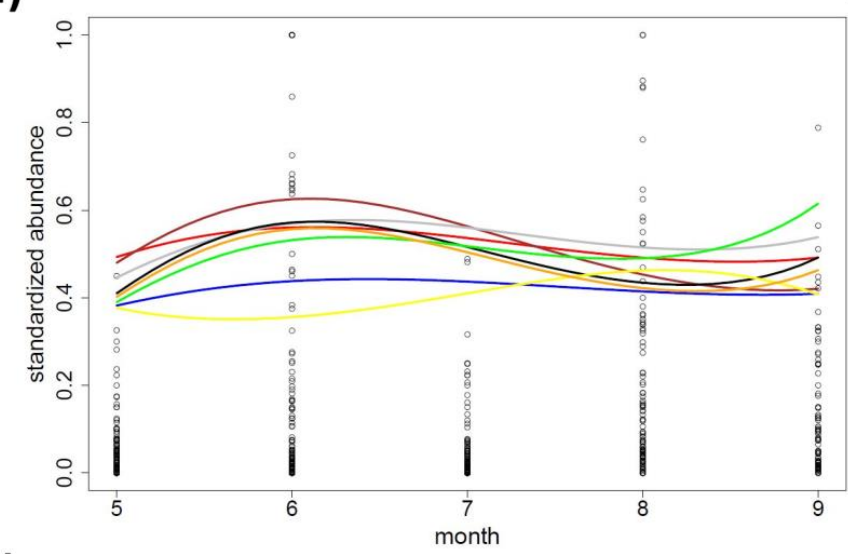

b)

c)

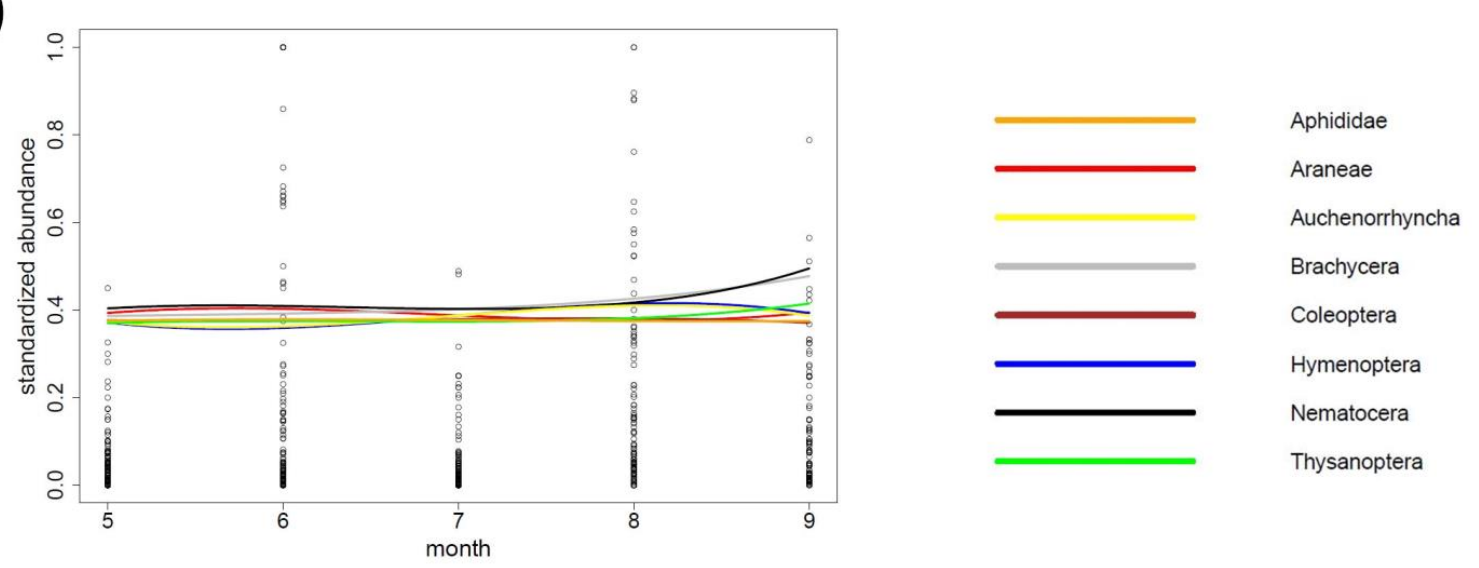

Figure 3 Relative taxon abundance of all taxa over time with predicted population progress over one year. a) The modelled population prediction for taxon abundance displays a high peak in June for all taxa except leafhoppers, where the highest abundance is reached in August. The abundance approximately varies between 0.38 and 0.65 b) Collapsed standardized taxon abundance for planted island treatment. Abundances are approximately equal, varying around a value of 0.4 with only one peak in August in Brachycera (around 0.48). c) Completely collapsed standardized taxon abundance in the non-planted island treatment. All values vary around 0.4 . with no displayable population peaks during one year of observation. 
As spiders have the ability to distribute over large distances due to their passive distribution mechanism of ballooning and rafting, they are commonly categorized as good colonizers (Garb \& Gillespie, 2006; Szymkowiak, Górski, \& Bajerlein, 2007; Zabka \& Nentwig, 2000). The most common form of dispersal - 'ballooning' - is dependent on wind speed and humidity (Reynolds, Bohan, \& Bell, 2007). As month had no effect on distribution, we did not find seasonal waves of spider migration, presumably due to the fact that juvenile and adult spiders can migrate all through the year depending on species identity.

Aphids were good colonizers too. Species with small wingless offspring, a broad host range and an anholocycle lifestyle support colonization success after entering a new habitat (Mondor, Tremblay, \& Messing, 2007). Similar to spiders, aphids can be passively distributed via rafting on plant material or aerial transportation - in this case 'flight'. It is known, that aphids can be passively distributed, but in the last state of transportation, they actively decide flight direction (Parry 2013). Once arrived, aphids can reproduce in high numbers and therefore rapidly conquer new island patches with host plants. In our results, abundance of aphids in planted island plots was higher than in non-planted plots.

Flies are well known as widely dispersing taxon, even over large oceanic distances (Bröring, 2009; Goodman \& O'Grady, 2013; Heydemann, 1967; Yoshimoto, Gressitt, \& Mitchell, 1962). Plenty of studies focus on hoverflies and drosophilid flies, which can fly over large distances (>300km) within one uninterrupted flight.

The large order of Coleoptera includes good as well as clumsy flyers. Rove beetles are extraordinary good flyers with the ability of a large dispersal and colonization range and success (Marcelino et al., 2016; Rose \& Möhlmann, 1993; Rose et al., 2006). Depending on their dietary range, beetles can be good colonizing insects (Kotze, Niemelä, \& Nieminen, 2000).

In the order of Hymenoptera, especially ants and parasitoid wasps tend to be good colonizing groups (Heydemann 1967, MacArthur and Wilson 1967, Simberloff and Wilson 1969). They both can colonize via active flight or rafting (also important for fertilized ant queens).

Nematocera also tend to succeed over large distances (Bröring 2009, Goodman and Grady 2013). As most of Nematocera belong to aerial plankton, they are commonly 
passively distributed. Especially chironomid communities are well researched (Raposeiro, Costa, \& Hughes, 2011), but no mechanisms are given so far.

For Thysanoptera, only a few studies have been published so far. Simberloff and Wilson reported in 1969, that Tysanoptera did colonize newly establishing mangrove islands, but endured for at least 3 months. They argue, that ants predate on thrip species and therefore heavily reduce populations.

On a taxonomic order level, several traits may explain the observed differences in colonization success. Such traits include dispersal ability (Borda-de-Água et al., 2017), trophic breadth (Gravel, Massol, Canard, Mouillot, \& Mouquet, 2011; Jacquet, Mouillot, Kulbicki, \& Gravel, 2017) and body size (Pedley \& Dolman, 2014; Wu, Li, \& Murray, 2006). As most of affected taxa (Aphididae, Auchenorrhyncha, Brachycera, Nematocera, Thysanoptera) rely on herbaceous plant resources, only planted experimental island plots could provide food resources.

Reduced number of individuals on the islands can be also shown via modelled standardized abundances. Population peaks in June and September on the Spiekeroog control plots were no longer visible on the experimental islands or are slightly shifted (fly species have their low species maximum in August instead of June).

In conclusion, for the first time, we artificially constructed experimental islands close to a barrier island and studied island colonization by arthropods. We observed seasonal differences over one year in this experiment and established differences between experimental treatments. Most of the taxa were influenced by the experimental treatment with taxa differing in favor of planted vs non-planted islands, while less taxa were affected by month or the interaction of month and treatment.

Further experiments over a longer period of time should be conducted to monitor populations also during storm tide events (October to March of the following season). Heavy storms and high waves during high tides complicate sampling by traps. Therefore, designing new traps with more resilient devices would be an important improvement, as well as more detailed analyses of species identity and traits such as trophic level position. 


\section{References}

Anderson, G. S., \& Bell, L. S. (2016). Impact of marine submergence and season on faunal colonization and decomposition of pig carcasses in the salish sea. PLOS ONE, 11(3). http://doi.org/10.1371/journal.pone.0149107

Bährmann, R. (2008). Bestimmung wirbelloser Tiere (4th ed., Vol. 5). Munich: Elsevier. http://doi.org/10.1007/978-3-642-55395-0

Barton, P. S., Cunningham, S. A., Macdonald, B. C. T., McIntyre, S., Lindenmayer, D. B., \& Manning, A. D. (2013). Species Traits Predict Assemblage Dynamics at Ephemeral Resource Patches Created by Carrion. PLOS ONE, 8(1).

http://doi.org/10.1371/journal.pone.0053961

Borda-de-Água, L., Whittaker, R. J., Cardoso, P., Rigal, F., Santos, A. M. C., Amorim, I. R., ... Borges, P. a. V. (2017). Dispersal ability determines the scaling properties of species abundance distributions: a case study using arthropods from the Azores. Scientific Reports, 7(1), 3899. http://doi.org/10.1038/s41598-017-04126-5

Bröring, U. (2009). Systematic and Biogeographical Account of the Midges and Flies ( Diptera ) of the East Frisian Islands. BTU Cottbus, LS Allgemeine Ökologie, Printed $d r$, $1-17$.

Charbonneau, B. R., Wootton, L. S., Wnek, J. P., Langley, J. A., \& Posner, M. a. (2017). A species effect on storm erosion: Invasive sedge stabilized dunes more than native grass during Hurricane Sandy. Journal of Applied Ecology, 1385-1394. http://doi.org/10.1111/1365-2664.12846

Dunger, W., \& Fiedler, H. J. (1999). Methoden der Bodenbiologie BESTIMMUNGSTAFELN. (H. Friedler \& W. Dunger, Eds.) (2nd ed.). Jena: Gustav-Fischer-Verlag.

Farwig, N., Brandl, R., Siemann, S., Wiener, F., \& M??ller, J. (2014). Decomposition rate of carrion is dependent on composition not abundance of the assemblages of insect scavengers. Oecologia, 175(4), 1291-1300. http://doi.org/10.1007/s00442-0142974-y

Folmer, O., Black, M., Hoeh, W., Lutz, R., \& Vrijenhoek, R. (1994). DNA primers for amplification of mitochondrial cytochrome c oxidase subunit I from diverse metazoan invertebrates. Molecular Marine Biology and Biotechnology, 3(5), 294299. http://doi.org/10.1371/journal.pone.0013102

Foster, T. E., Stolen, E. D., Hall, C. R., Schaub, R., Duncan, B. W., Hunt, D. K., \& Drese, J. H. (2017). Modeling vegetation community responses to sea-level rise on Barrier Island systems: A case study on the Cape Canaveral Barrier Island complex, Florida, USA. PLoS ONE, 12(8), 1-22. http://doi.org/10.1371/journal.pone.0182605

Garb, J. E., \& Gillespie, R. G. (2006). Island hopping across the central Pacific: mitochondrial DNA detects sequential colonization of the Austral Islands by crab spiders (Araneae: Thomisidae). Journal of Biogeography, 33(2), 201-220. http://doi.org/10.1111/j.1365-2699.2005.01398.x 
Goodman, K. R., \& O'Grady, P. (2013). Molecular Phylogeny and Biogeography of the Hawaiian Craneflies Dicranomyia (Diptera: Limoniidae). PLoS ONE, 8(9). http://doi.org/10.1371/journal.pone.0073019

Gravel, D., Massol, F., Canard, E., Mouillot, D., \& Mouquet, N. (2011). Trophic theory of island biogeography. Ecology Letters, 14(10), 1010-1016. http://doi.org/10.1111/j.1461-0248.2011.01667.x

Hadziavdic, K., Lekang, K., Lanzen, A., Jonassen, I., Thompson, E. M., \& Troedsson, C. (2014). Characterization of the 18s rRNA gene for designing universal eukaryote specific primers. PLoS ONE, 9(2). http://doi.org/10.1371/journal.pone.0087624

Hall, T. a. (1999). BioEdit: a user-friendly biological sequence alignment editor and analysis program for Windows 95/98/NT. Nucleic Acids Symposium Series. http://doi.org/citeulike-article-id:691774

Hayes M.O. (1979). Barrier island morphology as a function of tidal and wave regime. In Leatherman S.P. [ed.], Barrier Islands. Academic Press, New York, pp. 1-27., (July).

Heaney, L. R. (2000). Dynamic disequilibrium: a long-term, large-scale perspective on the equilibrium model of island biogeography. Global Ecology and Biogeography, 9(1), 59-74. http://doi.org/10.1046/j.1365-2699.2000.00163.x

Heydemann, B. (1967). Der Ueberflug von Insekten ueber Nord- und Ostsee nach Untersuchungen auf Feuerschiffen, Deutsche Entomologische Zeitschrift, 14 (1-2), 185-215.

Jacquet, C., Mouillot, D., Kulbicki, M., \& Gravel, D. (2017). Extensions of Island Biogeography Theory predict the scaling of functional trait composition with habitat area and isolation. Ecology Letters, 20(2), 135-146.

http://doi.org/10.1111/ele.12716

Kotze, D. J., Niemelä, J., \& Nieminen, M. (2000). Colonization success of carabid beetles on Baltic islands. Journal of Biogeography, 27(4), 807-819.

http://doi.org/10.1046/j.1365-2699.2000.00456.x

Losos, J. B., Warheitt, K. I., \& Schoener, T. W. (1997). Adaptive differentiation following experimental island colonization in Anolis lizards. Nature.

http://doi.org/10.1038/387070a0

MacArthur, R., \& Wilson, E. O. (1967). The theory of island biogeography (13th ed.). Princeton: Princeton University Press.

Marcelino, J. A. P., Giordano, R., Borges, P. A. V., Garcia, P. V., Soto-Adames, F. N., \& Soares, A. 0. (2016). Distribution and genetic variability of staphylinidae across a gradient of anthropogenically influenced insular landscapes. Bulletin of Insectology, 69(1), 117-126. 
Mondor, E. B., Tremblay, M. N., \& Messing, R. H. (2007). Morphological and ecological traits promoting aphid colonization of the Hawaiian Islands. Biological Invasions, 9(1), 87-100. http://doi.org/10.1007/s10530-006-9010-z

Oosterbroek, P. (2007). The European families of the Diptera. Identification, diagsnosis, biology, 205. http://doi.org/1

Parmenter, R. R., \& Macmahon, J. A. (2009). Carrion Decomposition and Nutrient Cycling in a Semiarid Shrub - Steppe Ecosystem Author ( $\mathrm{s}$ ): Robert R. Parmenter and James A . MacMahon Published by : Wiley Stable URL : http://www.jstor.org/stable/40385231 REFERENCES Linked references are available o, 79(4), 637-661.

Parmenter, R. R., \& MacMahon, J. A. (2009). Carrion decomposition and nutrient cycling in a semiarid shrub- steppe ecosystem. Ecological Monographs, 79(4), 637-661. http://doi.org/10.1890/08-0972.1

Pedley, S. M., \& Dolman, P. M. (2014). Multi-taxa trait and functional responses to physical disturbance. Journal of Animal Ecology, 83(6), 1542-1552.

http://doi.org/10.1111/1365-2656.12249

Raposeiro, P. M., Costa, A. C., \& Hughes, S. J. (2011). Environmental factors - spatial and temporal variation of chironomid communities in oceanic island streams (Azores archipelago). Annales de Limnologie - International Journal of Limnology, 47(4), 325-338. http://doi.org/10.1051/limn/2011048

Rejmánek, M., Richardson, D. M., Barbour, M. G., Crawley, M. J., Hrusa, F. G., Moyle, P. B., ... Williamson, M. (2002). Biological invasions: politics and the discontinuity of ecological terminology. Bulletin of the Ecological Society of America, 131-133.

Reynolds, A. M., Bohan, D. a, \& Bell, J. R. (2007). Ballooning dispersal in arthropod taxa: conditions at take-off. Biology Letters, 3(3), 237-40.

http://doi.org/10.1098/rsbl.2007.0109

Richards, S. L., Connelly, C. R., Day, J. F., \& Hope, T. (2015). Arthropods associated with carrion in a salt marsh habitat in southeastern Florida. Florida Entomologist, 98(2), 613-619. http://doi.org/10.1653/024.098.0234

Rose, A., Bellmann, A., Büche, B., Esser, J., Maus, C., \& Renner, K. (2006). Kurzflügelkäfer der Ostfriesischen Inseln : unpublizierte Funde , Funddaten sowie Korrekturen ( Coleoptera , Staphylinidae: excl. Aleocharinae)-1.Teil. Drosera, 129-156.

Rose, A., \& Möhlmann, G. (1993). Zur Besiedlung der jungen Düneninsel Mellum durch Staphyliniden (Coleoptera: Staphylinidae). Drosera, 93(1), 101-123.

Rosenzweig, M. L. (1995). Species diversity in space and time (1st ed.). Cambridge: University of Cambridge Press.

Simberloff, D. S., \& Wilson, E. O. (1969). Experimental Zoogeography of Islands : The Colonization of Empty Islands Author ( s ): Daniel S. Simberloff and Edward 0 . 
Wilson Published by : Wiley on behalf of the Ecological Society of America Stable URL : http://www.jstor.org/stable/1934856 REFEREN, 50(2), 278-296.

Simberloff, D. S., \& Wilson, E. O. (1970). Experimental Zoogeography of Islands. A TwoYear Record of Colonization. Ecology, 51(5), 934-937.

Stutz, M. L., \& Pilkey, O. H. (2011). Open-ocean barrier islands: Global influence of climatic, oceanographic, and depositional settings. Journal of Coastal Research, 27(2), 207-222. http://doi.org/10.2112/09-1190.1

Szpila, K. (2010). Current concepts in forensic entomology. (J. Amendt, M. L. Goff, C. P. Campobasso, \& M. Grassberger, Eds.), Key for the Identification of Third Instars of European Blowflies (Diptera: Calliphoridae) of Forensic Importance (1st ed.). Heidelberg: Springer Verlag. http://doi.org/10.1007/978-1-4020-9684-6_3

Szpila, K. (2010). Key for the identification of third instars of european blowflies (Diptera: Calliphoridae) of forensic importance. Current Concepts in Forensic Entomology, 43-56. http://doi.org/10.1007/978-1-4020-9684-6_3

Szymkowiak, P., Górski, G., \& Bajerlein, D. (2007). Passive dispersal in arachnids. Biological Lett, 44(2), 75-101. Retrieved from www.biollett.amu.edu.pl

Tabor, K. L., Brewster, C. C., \& Fell, R. D. (2004). Analysis of the Successional Patterns of Insects on Carrion in Southwest Virginia. Journal of Medical Entomology, 41(4), 785-795. http://doi.org/10.1603/0022-2585-41.4.785

Udy, K. L., Fritsch, M., Grass, I., Hartig, F., Kneib, T., Kreft, H., Wiegand, K. (submitted). Environmental heterogeneity predicts global species richness better than area, 125.

Weigelt, P., Jetz, W., \& Kreft, H. (2013). Bioclimatic and physical characterization of the world's islands. Proceedings of the National Academy of Sciences of the United States of America, 110(38), 15307-12. http://doi.org/10.1073/pnas.1306309110

Wu, Z., Li, Y., \& Murray, B. R. (2006). Insular shifts in body size of rice frogs in the Zhoushan Archipelago, China. Journal of Animal Ecology, 75(5), 1071-1080. http://doi.org/10.1111/j.1365-2656.2006.01126.x

Yang, L. H., Bastow, J. L., Spence, K. O., \& Wright, A. N. (2008). What can we learn from resource pulses? Ecology, 89(3), 621-634. http://doi.org/10.1890/07-0175.1

Yoshimoto, B. C. M., Gressitt, J. L., \& Mitchell, C. J. (1962). TRAPPING OF AIR-BORNE INSECTS IN THE PACIFIC- ANTARCTIC AREA , 1. Pacific Insects, 4(4), 847-858.

Zabka, M., \& Nentwig, W. (2000). Salticidae (Arachnida: Araneae) of the Krakatau Islands (Indonesia) - A preliminary approach. Ekologia Bratislava, 19(9993), 293-306. 


\section{Acknowledgements}

We especially acknowledge the Ministry for Science and Culture of Lower Saxony, Germany for founding the BEFmate project (project number ZN2930). Michael Kleyer and Helmut Hillebrand for planning and initiating the BEFmate project, the scientific administration team of the 'Nationalpark-Haus Wittbülten' Spiekeroog, Charlotte Winkelmann and Swaantje Fock. For trap construction we especially thank Frank Gremmes and Harald Krumrey (Georg-August-Universität Göttingen) Last but not least, Lisa Denmead (Toi Ohomai Institute of Technology, Bay of Plenty, New Zealand) gave essential corrections on language issues. 


\section{CHAPTER 4:}

Diversity of decomposing flies and carcass decay in
experimental salt-marsh islands of the North Sea,
Germany

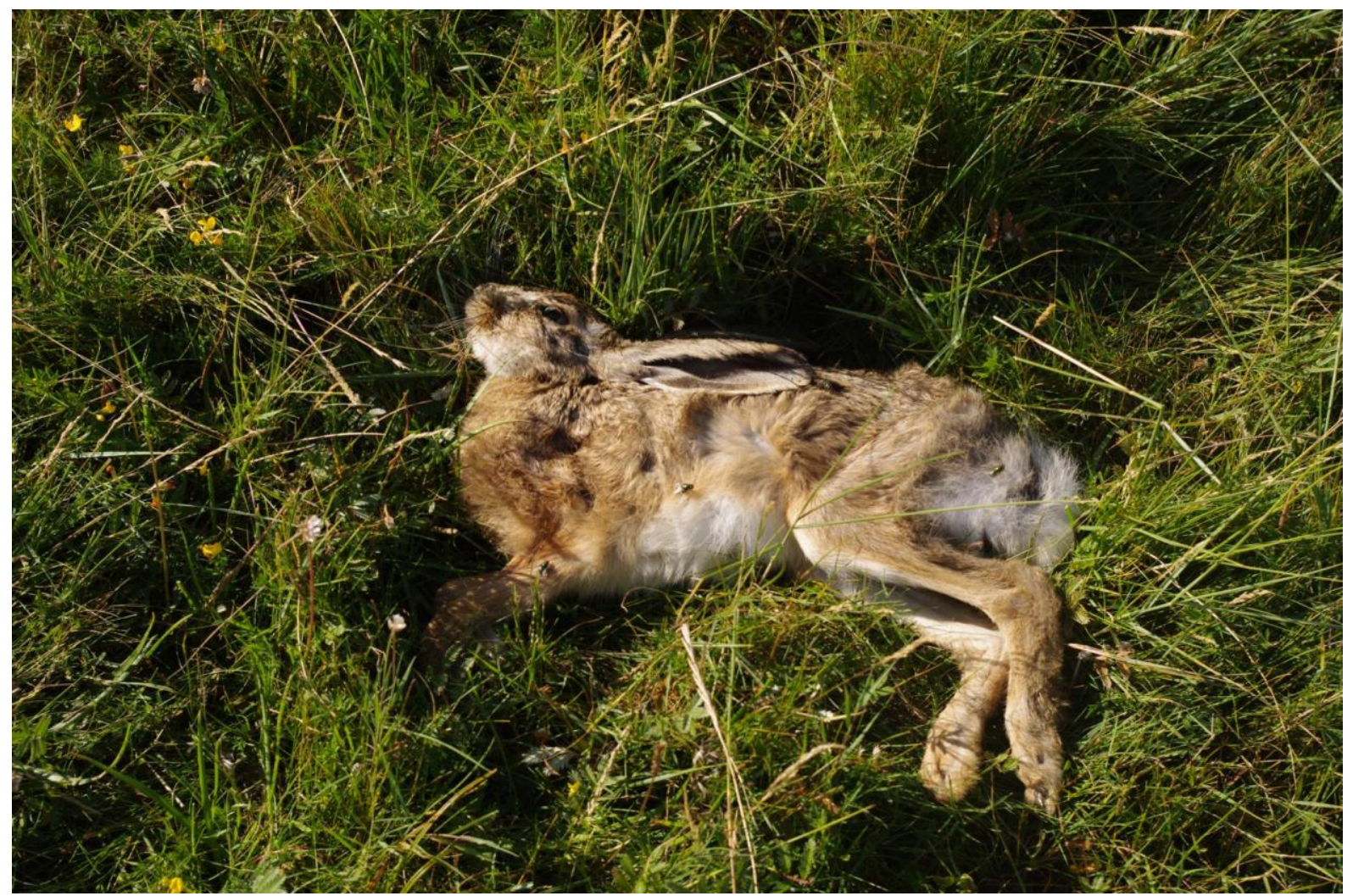

Hagen Andert ${ }^{1}$, Thomas Dinter ${ }^{1}$, Teja Tscharntke, Oliver Piskurek, Stefan Scheu, Yakov Kuzyakov, Christoph Scherber

${ }^{1}$ Equally contributing authors

To be submitted to Proceedings of the Royal Society $B$ 


\begin{abstract}
Understanding island colonization by organisms and their contribution to ecosystem functioning is a major focus in ecology, while colonization of standardized, experimental islands in the sea has been rarely been investigated. Decomposition is a major ecosystem service linking at least two trophic levels. Here, we performed an animal decomposition experiment using an experimental approach on the barrier island Spiekeroog, Germany. 264 pieces of cow meat were spread over 12 experimental islands and six control plots established in late 2014 to observe animal decay in a real-time experiment. Our two weeks experiment displayed the influence of time and experimental treatment (experimental island or control) on carcass biomass loss, whereas the habitat zonation on each of the 18 plots (pioneer zone, lower salt marsh and upper salt marsh) did not contribute to the explanation. Animal extraction from the carcass (a piece of cow meat) and the soil beneath the carcass highlighted maggots as the taxon with highest abundances, with Scatophaga stercoraria $(\mathrm{n}=670)$, Hydrotaea dentipes $(\mathrm{n}=590)$ and Spelobia luteilabris $(\mathrm{n}=235)$ playing a major role. Maggot community composition changed between marine pioneer zone up to terrestrial upper salt marsh zone. In pioneer zone plots, we recorded three maggot species, whereas in upper salt marshes, we found ten species. Interestingly, higher species richness of maggots was related to higher nutrient release during decomposition, resulting in a lower ratio of carbon and nitrogen in the soil under the carcass.
\end{abstract}

Keywords: animal decomposition, BEFmate, Brachycera, carcass, flies, salt marshes, soil organic matter, TTIB 


\section{Introduction}

For centuries, islands were in the main focus of several ecological and evolutionary studies as they are area restricted, mostly isolated and less complex than larger mainland areas (Whittaker 1998, Losos and Ricklefs, 2005). For the last 50 years, beside species interaction networks and the assembly of island communities through different time scales, colonization processes represented the main focus of island biogeography, initialized by the fundamental monography of MacArthur and Wilson (1967) (Santos, Field and Ricklefs 2016). Within the last years, research on ecosystem functioning has become more important, especially within the topics of parasite-host interactions and predation (Whittaker et al., 2014, Santos, Field and Ricklefs, 2016). As decomposition is one of the most important ecosystem functioning processes (Parmenter \& MacMahon, 2009), its effect on biodiversity and community ecology has become one of ecology's major topics over the last years (Parmenter \& MacMahon, 2009, Barton et al., 2013). The decomposition of animal carcasses acts as a short-lived and infrequent resource pulse (Yang, Bastow, Spence, \& Wright, 2008) with both short- and long- term effects on plant growth (Barton et al., 2013; Parmenter \& MacMahon, 2009). As a result, decomposing carcasses function as localized islands of enhanced species pools and soil fertility characterized by changes in the dominance structure of decomposers (Tabor, Brewster, $\&$ Fell, 2004). Microbial communities mineralize carcass tissue and transform complex organic compounds into readily plant-available nutrients (Parmenter \& MacMahon, 2009).

Attempts to model decomposition so far focused mainly on abiotic factors such as soil type, temperature, humidity or elevation (Tabor et al., 2004) and put emphasis on terrestrial habitats. Until now, studies neglected carcass decomposition processes on islands, and even principal processes such as biomass loss, accessibility of plant related nutrients or changes in decomposer community composition have remained largely unexplored (but see Richards et al 2016;Parmenter \& Macmahon, 2009). Studies in marine habitats show that there is a lack of insect scavengers, as insects are not permanent inhabitants of marine habitats. However, salinity and water saturation massively influence animal tissue decomposition (Anderson \& Bell, 2016; Richards, Connelly, Day, \& Hope, 2015). Previous studies have used existing gradients in salt marsh habitats; here, we employ a less common approach by establishing artificial salt marsh islands differing in disturbance intensity. This allows, in contrast to previous 
studies, to isolate effects of particular explanatory variables on the decomposition process. We expose cow meat pieces and study ecosystem processes on $\mathrm{N}=10$ experimental islands and eight natural salt marsh controls in a salt marsh system. We examine the abundance and species richness of carcass decomposing flies and larvae as a function of abiotic factors (i.e. salinity, water saturation, soil texture etc). Further, we study the short-term enrichment in carbon, nitrogen and plant- available phosphorous in the soil beneath the decaying substrate. We explicitly link decomposition to community attributes.

We hypothesize that (1) animal decay proceeds more slowly in the marine-influenced pioneer zone than in the terrestrial upper salt marsh, (2) decomposing invertebrate communities differ between experimental islands and salt marsh control plots, (3) decomposition-triggered nutrient release is driven by decomposing maggot species and therefore (4) plant available nutrients differ depending on decomposition process.

\section{Material and Methods}

\section{Study area}

The experiment was conducted in the Southern region of Spiekeroog island (Germany, $53^{\circ} 45^{\prime} 31^{\prime \prime} \mathrm{N}, 7^{\circ} 43^{\prime} 30^{\prime \prime} \mathrm{E}$ ) within the Wadden Sea (a World Natural Heritage site). Spiekeroog is one of eleven East Frisian barrier islands that had been formed during the Holocene mostly by sedimentation- and erosion processes that still continue to shape island morphology (Streif 1990). Towards the Wadden Sea, the transition from a terrestrial to a marine environment results in three main habitat zones: (1) pioneer zone (Pio), (2) lower salt marshes (Low) and (3) upper salt marshes (Upp). Pio is characterized by daily inundation every six hours and has an average altitude of 1 meter above mean sea level (amsl). Dominant plant species are Spartina anglica, adapted to high salt concentrations. Low is an intermediate zone between Pio and Upp with $1.5 \mathrm{~m}$ amsl being flooded only during spring tide events. Puccinellia maritima and Aster tripolium are typical plant species in this zone. Upp has an average altitude of 2.5 meters amsl and is not regularly inundated by sea water, except when storm tide events take place. In the study area, Upp is dominated by Elymus athericus. The soil of the sampling site is a salic fluvisol (WRB) which is characterized by loamy sand overlain by a 20- 
$30 \mathrm{~cm}$ thick layer of clayey to sandy silt. Mean temperature for September 2015 was $14.44^{\circ} \mathrm{C}$ with negligible precipitation.

\section{Experimental Design}

In autumn 2014, N=12 artificial islands were installed in the Wadden Sea, $500 \mathrm{~m}$ south of Spiekeroog. Detailed information about the construction and experimental design of the artificial islands can be found in Balke et al. (2017). Half of the experimental islands (EI) as well as onshore artificially transplanted control plots (SM) were prepared in September 2015 by transplanting salt marsh sods (Figure 1).

Transplanted plots are located in the three naturally occurring salt marsh zones mentioned above. Half of these transplanted plots are modified by either vegetation removal and Wadden Sea mud replacement or vegetation removal and replacement by lower saltmarsh vegetation sods (Figure 2). Experimental islands were filled with Wadden Sea sediment ca. $30 \mathrm{~m}$ aside from experimental island location in the Wadden Sea. Additionally, in planted experimental islands, $30 \mathrm{~cm}$ thick sods from onshore Lowzone were placed on top of the sediment.

A similar procedure took place on transplanted plots: half of the plots on the barrier island itself were either filled with sediment or additionally topped with vegetation sods from a close-by lower salt marsh area. We used five planted and non-planted transplanted plots and five non-planted and planted experimental island plots in all three habitat zones. Plots were separated five meters from each other within each habitat zone. Each habitat zone had an approximate distance of $100 \mathrm{~m}$ to another one. 
Experimental islands were separated $55 \mathrm{~m}$ from each other (Figure 1).

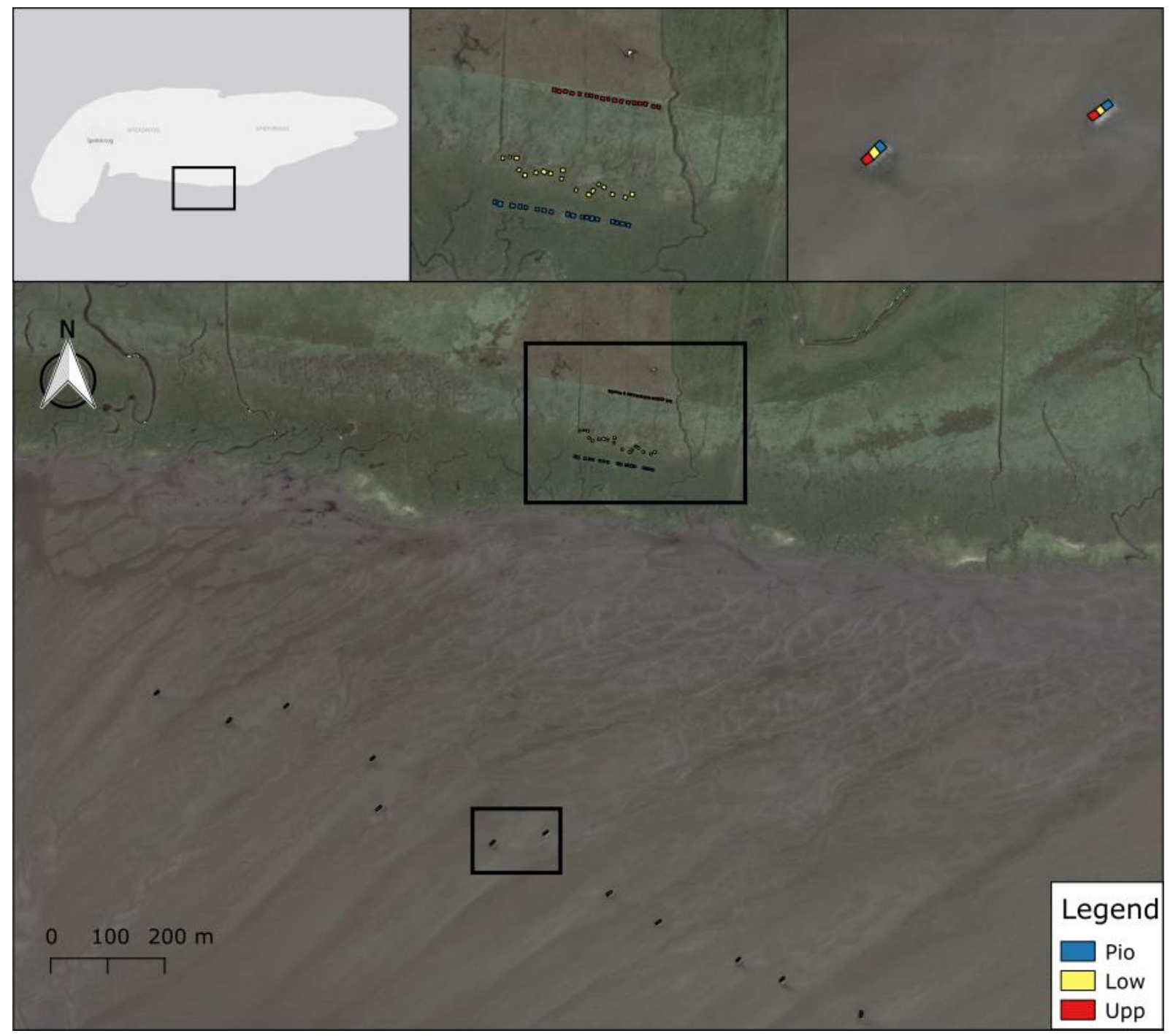

Figure 1 Location and design of experimental plots and different habitat zonation. Displays the whole experimental setup with all 12 experimental islands and all transplanted plots. In b a close-up of transplanted plots display a habitat sequence from upper saltmarsh, lower salt marsh and pioneer zone from North to South. As opposed to this, the same habitat sequence in experimental islands is oriented from South to the North. This opposed design is due to the direction of water flow-off, which would in the experimental design cause immense erosion.

In September 2015, we cut 264 pieces of homogenous non-organic cow meat (local butcher from Göttingen, Germany, 30g wet weight (corresponding dry weight of mean $7.763 \mathrm{~g}$ ) and $3 \times 3 \mathrm{~cm}$ size). The substrate was wrapped in PVC-covered chicken wire (mesh size: $25 \mathrm{~mm}$ ), with spines drilled to prevent attacks by scavenging birds or mammals in the field. Three of each were anchored in the substrate with two tied wooden sticks as a protection against tidal currents per plot. To measure initial conditions, soil cores (5 $\mathrm{cm}$ diameter, depth $3 \mathrm{~cm}$ ) were sampled to determine initial soil 
arthropod fauna and soil element status. After 3, 7 and 14 days, one out of three decaying meat pieces per plot were randomly sampled into zip bags (1 L volume) and stored at $4^{\circ} \mathrm{C}$ until further analysis. The same procedure was employed for soil samples using a $7 \times 5 \mathrm{~mm}$ corer. Soil samples were randomly divided into two halves for arthropod extraction and soil nutrient analysis. Flies and other easily accessible arthropods were collected from each piece using spring steel forceps and put into $70 \%$ ethanol. For the extraction of remaining larvae and adults, the zip bag was filled with water and shaken for 20 seconds. The supernatant was filtered through a strainer (1 mm mesh size), washed again and filled into Falcon tubes (50 mL, Sarstedt, Inc.) with $70 \%$ ethanol. Remaining pieces of meat were dried in a drying oven (Memmert $\mathrm{GmbH}$, Germany) for four days at $65^{\circ} \mathrm{C}$ and maximal aeration and weighed (Sartorius $\mathrm{AG}$, Germany). Air-dried soil samples were ground and sieved to $2 \mathrm{~mm}$ for further procedures. One aliquot served as sample for Carbon (C) and Nitrogen (N) analysis and was ball-milled (200 rpm/5 min, Retsch GmbH). C and $\mathrm{N}$ were determined in a combustion furnace photometrically (vario EL III; elementar, Hanau, Germany). Another aliquot was used to measure available phosphorous \{Schüller $1969 \# 31$ \} and \{Blume 2011 \#23\}: $2 \mathrm{~g}$ of soil were diluted into $40 \mathrm{~mL}$ Calcium-Acetat-Lactate (CAL)-solution and shaken for $90 \mathrm{~min}$ in PE-bottles. After filtration, liquid samples were amended with a molybdate-complex and measured photometrically with a microplate reader at 820 nm wavelength (Infinite $₫ 200$ Pro, Tecan Switzerland).

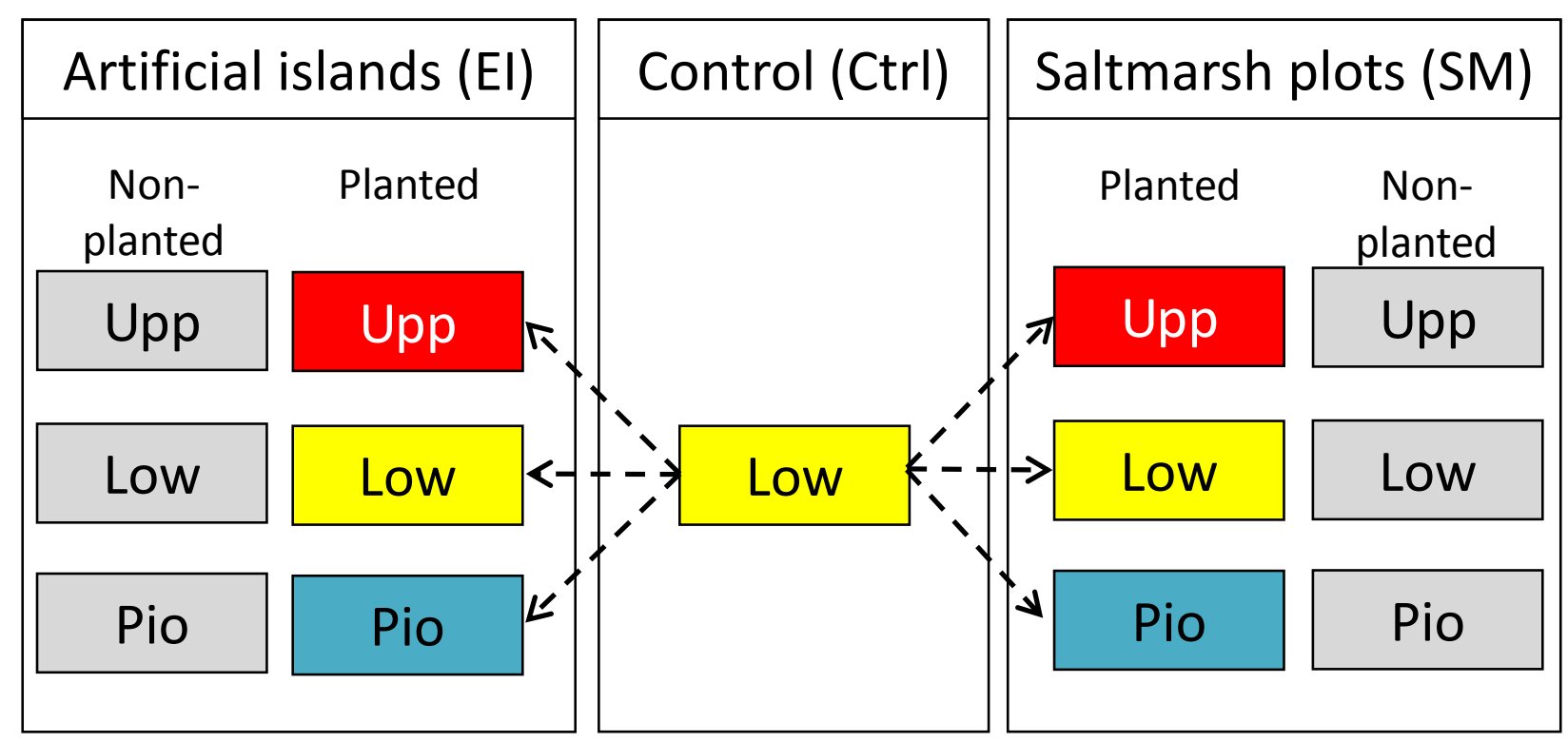


Figure 2 Experimental design of sod transplantation after Balke et al. 2017. Lower salt marsh sods were taken from natural vegetation of Spiekeroog and then transplanted onto Wadden Sea mud filled plots in transplanted plots or sediment filled gabions in experimental islands. Beside so called planted plots, also non-planted plots occur, which were filled with Wadden Sea sediment only.

\section{Soil arthropod extraction}

Soil arthropods were extracted by using a Kempson extractor (Kempson et al. 1963) following a commonly used protocol (S1) for 8 days. Arthropods were extracted into ethylene glycol and directly transferred into 70\% EtOH after washing.

\section{Animal identification}

Arthropod families were identified under a stereomicroscope (Leica) using taxonomic literature (Dunger \& Fiedler, 1999; Bährmann, 2008; Schäfer 2017). Adult flies were identified to family level (Oosterbroek, 2007). Fly larvae were identified using taxonomic keys (Szpila, 2010; Szpila, 2010); identification was additionally verified using a barcoding approach and expert opinions. To identify decomposition-related maggot species, we used amplified 730bp sequences from the C01 region (Table 1) for a modified PCR protocol. Further information on barcoding and the sequencing protocol are given in $\mathrm{S} 2$.

Table 1 COI primer sequences used for barcoding of maggot species.

$\begin{array}{ll}\text { Primer } & \text { Primer sequence }\left(\mathbf{5}^{\mathbf{}} \mathbf{- >} \mathbf{3}^{\prime} \mathbf{)}\right. \\ \text { ForEnt COI up } & \text { TTTCTACTAATCATAAAGATATTGGWACT } \\ \text { ForEnt COI low } & \text { AATCCAGGTAAAATTAAAATATATACTTC } \\ \text { Insect 18S for } & \text { GAAGGCGATCAGATACCGCCCTAGTTCTA } \\ \text { Insect 18S rev } & \text { GTAGCGCGCGTGCRGCCCA }\end{array}$

\section{Statistical Analyses}

Data were analyzed using R 3.3.2. (R Development Core Team 2016) using the packages 'effects' for model display, 'fitdistrplus' to fit parametric distributions, 'Ime4' to fit linear mixed-effect models, 'MASS' for ANOVA, 'MuMIn' for model selection via AICc, 'splines' to provide our models with B-splines, 'survey' for generating summary statistics and 
'vegan' to calculate alpha-diversity, species richness and perform PERMANOVA analysis. Species richness of eleven decomposition-related maggot species were calculated via the package 'vegan'. In this study, maggot abundance data and species richness were used as biotic variables. For biotic parameters, we used glmmPQL models from the 'MASS'package due to their negative binomial error distribution (see R-code, Appendix A1). Additionally, we checked for homogenously distributed random effects. In all cases, time had no effect on biotic variables. To exclude time as variable, we aggregated abundance of different maggot taxa with plot, zone and planted/ non-planted treatment. To measure animal tissue decay, we assumed a nonlinear decay model after Olson (1963) (Eq.1).

\section{$\mathrm{x} / \mathrm{x}_{0}=\exp \left(-\mathrm{k}^{*} \mathrm{t}\right) \mathrm{Eq} .1$}

We linearized this model by taking logs on both sites and then analyzed data in a mixedeffects model as follows (Eq.2)

\section{$\log \left(\mathrm{x}_{\mathrm{t}} / \mathrm{x}_{0}\right)=\log \left(\mathrm{x}_{\mathrm{t}}\right)-\log \left(\mathrm{x}_{0}\right)=-\mathrm{k}^{*} \mathrm{t}$}

Based on the formula by Olsen (1963), we calculated a coefficient of decay ('k') for each data point after the initial measurement $\left(\mathrm{t}_{0}\right)$. Mixed-effects models contained plot (i.e. site, a factor with two levels) and zone (a factor with three levels) nested within plot as random effect. Predicted values were back-transformed by taking antilogs. We checked for effects of time, Shannon diversity of arthropods, species richness and total abundance of these animals both above and below ground on decomposition. To investigate the relationship of species occurrence probability in different plots and zones, we used poisson distributed manyglm and multinomial log-linear models to predict occurrence probability.

Finally, we used further mixed models to assess the relationship between maggotrelated variables (maggot abundance, species richness and abundance of the three most abundant species Hydrotaea dentipes, Scatophaga stercoraria and Spelobia luteilabris) and the ratio change of carbon an nitrogen $(\mathrm{C} / \mathrm{N})$ over one decomposition period. These models contained plot identity, habitat zone and above or below ground location as random effects. Model fit was assessed using Akaike's information criterion, corrected 
for small sample sizes (AICc), and the best fit models were selected as those with $\triangle \mathrm{AICc}$ <2. (after Burnham \& Anderson 2002).

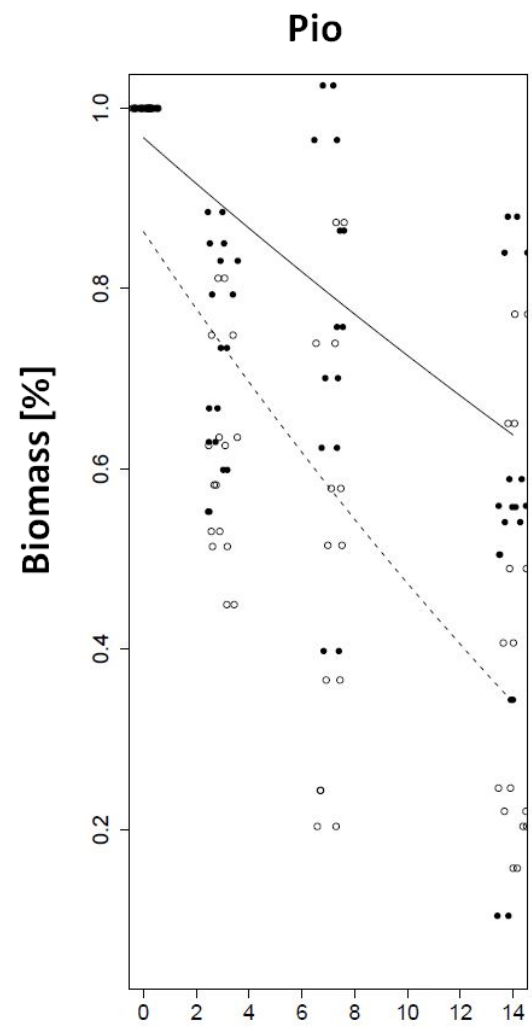

Day of decomposition

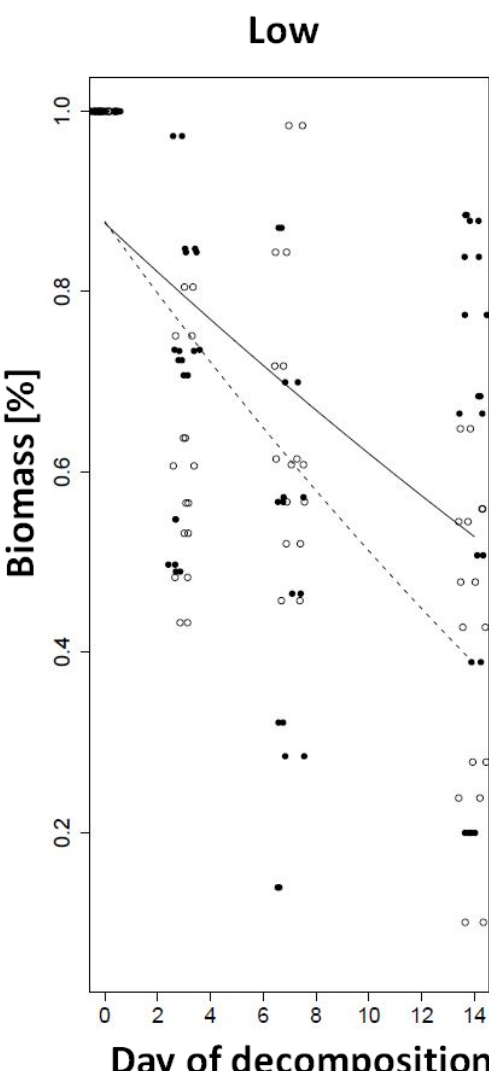

Day of decomposition

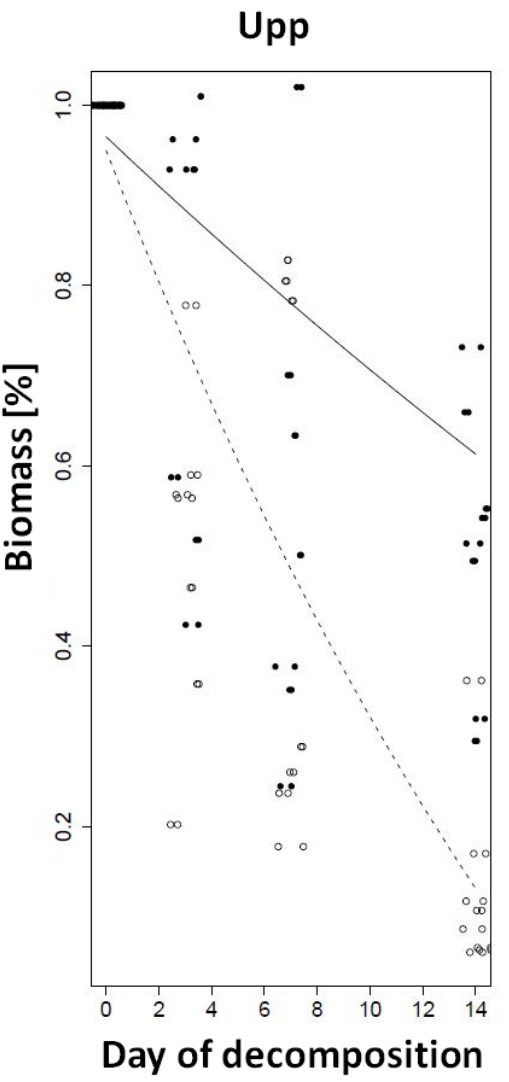

Figure 3 Biomass loss of decaying cow meat over 14 days of decomposition. Our model prediction displays the amount of remaining biomass after ongoing decomposition time. Biomass loss could be observed in all plots. Between experimental treatments (transplanted=continuos line, experimental islands=dashed line) significant differences could be found via or lme. In experimental islands, no difference between zones could be recognized, but in transplanted plots, a significant difference could be calculated.

\section{Results}

The best fit linear mixed-effects model showed a highly significant positive influence of increasing time of decomposition (numDF=1, denDF=372, $F=233.1504, p<0.001$ ) and plot identity (numDF=1, denDF=16, $\mathrm{F}=13.3183$, $\mathrm{p}<0.005$ ) on carcass biomass loss. There were characteristic differences in the predicted decomposition curve: For all three zones, the biomass loss was not significantly different (numDF $=2, \operatorname{denDF}=32, \mathrm{~F}=0.89$, p=0.4206). In control plots, decomposition differed between zones: From more marine to terrestrial influenced salt marsh habitats, the rate of weight-loss increased and hence, 
the amount of remaining carcass tissue after 14 days showed strong differences: At the end of the experiment, around $40 \%$ of carcass tissue remained in pioneer and lower salt marsh plots, whereas less than $10 \%$ of original carcass weight remains in a more terrestrial surrounding (Figure 3, S3, S4).

Table 2 Abundance data of maggot species. 11 maggot species occurred to be the most abundant ones in the experiment. Scatophaga stercoraria $(\mathrm{n}=670)$, Hydrotaea dentipes $(\mathrm{n}=590=$ and Spelobia luteilabris $(n=235)$. These three species display a higher abundance in transplanted plots compared to experimental islands plot. Both S. stercoraria and S. luteilabris show higher numbers in non-planted transplanted plots compared to planted transplanted plots in contrast to H. dentipes, which was more abundant in planted transplanted plots. In experimental island plots, all three species occurred more in planted plots than in non-planted experimental island plots.

\begin{tabular}{|c|c|c|c|c|c|c|c|c|c|c|c|c|}
\hline \multirow{4}{*}{ taxon } & \multicolumn{12}{|c|}{ experimental treatment } \\
\hline & \multicolumn{6}{|c|}{ transplanted plots } & \multicolumn{6}{|c|}{ experimental islands } \\
\hline & \multicolumn{3}{|c|}{ non-planted } & \multicolumn{3}{|c|}{ planted } & \multicolumn{3}{|c|}{ non-planted } & \multicolumn{3}{|c|}{ planted } \\
\hline & PZ & LSM & USM & PZ & LSM & USM & PZ & LSM & USM & $\mathbf{P Z}$ & LSM & USM \\
\hline Calliphora vicina & 0 & 0 & 47 & 0 & 1 & 45 & 0 & 0 & 57 & 0 & 8 & 0 \\
\hline Fannia canicularis & 0 & 0 & 3 & 0 & 15 & 5 & 0 & 0 & 0 & 0 & 0 & 1 \\
\hline Fucellia tergina * & 0 & 0 & 0 & 0 & 0 & 0 & 0 & 0 & 5 & 0 & 0 & 0 \\
\hline Hydrotaea dentipes & 0 & 25 & 90 & 0 & 82 & 185 & 6 & 1 & 49 & 87 & 21 & 44 \\
\hline Lucilia silvarum & 0 & 0 & 15 & 0 & 2 & 12 & 4 & 0 & 19 & 0 & 32 & 3 \\
\hline Muscina levida & 1 & 5 & 11 & 0 & 0 & 8 & 0 & 0 & 0 & 0 & 0 & 0 \\
\hline Sarcophaga jacobsoni & 0 & 36 & 27 & 1 & 20 & 16 & 5 & 0 & 0 & 0 & 8 & 18 \\
\hline Scatophaga litorea & 0 & 2 & 7 & 0 & 187 & 3 & 4 & 0 & 0 & 0 & 0 & 3 \\
\hline Scatophaga stercoraria & 8 & 374 & 62 & 0 & 144 & 33 & 1 & 0 & 10 & 11 & 23 & 4 \\
\hline $\begin{array}{l}\text { Rhegmoclematini gen. } \\
\text { sp.** }\end{array}$ & 0 & 2 & 21 & 0 & 1 & 1 & 3 & 0 & 0 & 13 & 39 & 32 \\
\hline Spelobia luteilabris & 3 & 22 & 73 & 0 & 32 & 29 & 1 & 7 & 2 & 3 & 8 & 54 \\
\hline
\end{tabular}

*after Grossmann, Fucellia tergina presumably is the most abundent species of this genus in the experimental area.

** after Niedringhaus et al. 2008 only Scatopse notata is recorded so far. Jean-Paul Haenni identified 
In our experiment, 9,969 specimens from 23 taxa have been caught within 14 days of decomposition. Eight main taxa (Figure 4) displayed 69.5\% of all specimens, including 2,507 fly larvae, which represent about $25 \%$ of all individuals. Within the Diptera larva (Table 2), 11 species were decomposer species according to their larval development and adult ecology: Calliphora vicina RoBINEAU-DESvoIDY, 1830, Fannia canicularis (LinnaEus, 1761), Fucellia tergina RoBINEAU-DESVOIDY, 1842, Hydrotaea dentipes (FABricius, 1805), Lucilia silvarum (MEIGEN, 1826), Muscina levida (HARRIS, 1780), Sarcophaga jacobsoni (RoHDENDORF, 1937), Scatophaga litorea VILLENEUVE, 1917, Scatophaga stercoraria (LinNAEuS, 1758), Rhegmoclematini gen. sp. and Spelobia luteilabris (RondANI, 1880). The most abundant species were Scatophaga stercoraria $(\mathrm{n}=670)$, Hydrotaea dentipes $(\mathrm{n}=590)$ and Spelobia luteilabris $(\mathrm{n}=235)$ (Figure 5).

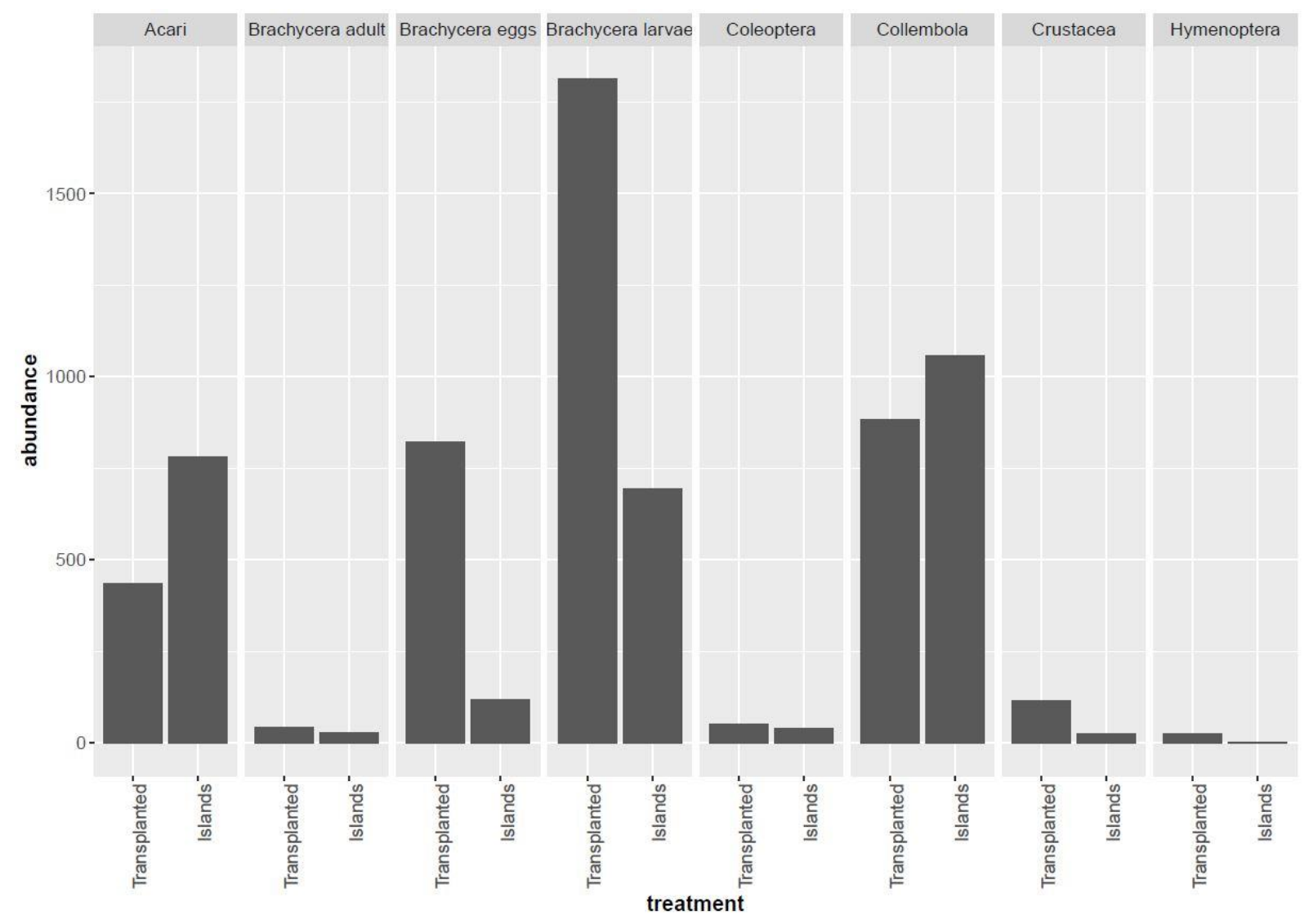

Figure 4 Abundance of most abundant taxa above and below our experimental setup. In our experimental setting, eight taxa occurred the most (in the order of highest abundance): Brachycera larvae (maggots), Collembola, Acari, Brachycera eggs (unhatched, fresh), Crustacea, Coleoptera, adult Brachycera 
and Hymenoptera. Brachycera larvae were verified the most, $n=3301$ ). In summary, carcass of transplanted plots contained three times more individuals than experimental islands plots.
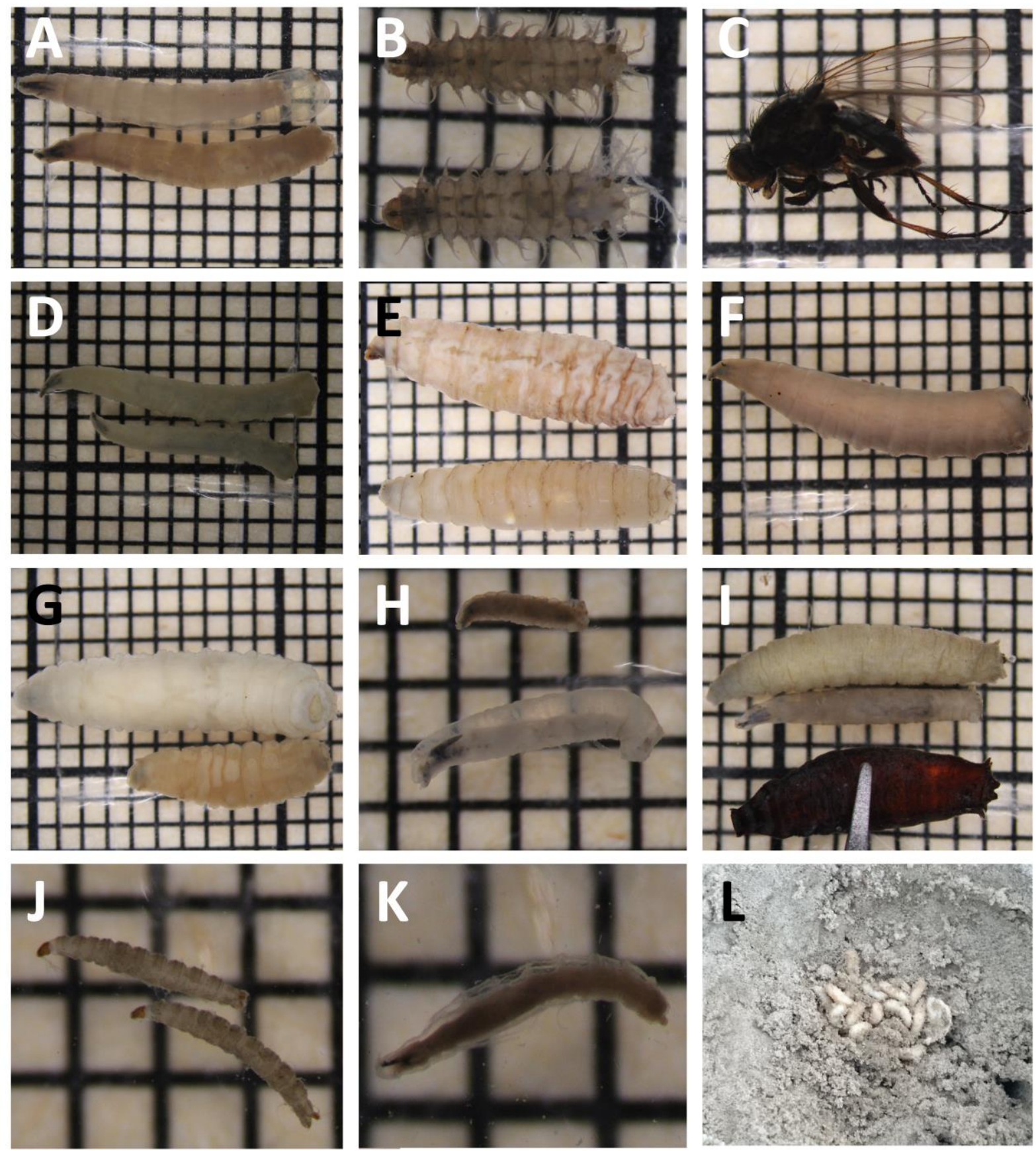

Figure 5 Pictures of 11 most abundant decomposition related maggot species. $\mathrm{A}=$ Calliphora vicina RoBInEAU-DESVOIDY, 1830, B= Fannia canicularis (LINNAEUS, 1761), C= Fucellia tergina RoBINEAU-DESVOIDY (no maggot can be displayed here, shown adult is hatched from pupa), 1842, $\mathrm{D}=$ Hydrotaea dentipes (FABricius, 1805), E= Lucilia silvarum (MEIGEN, 1826), F= Muscina levida (HARRIS, 1780), G= Sarcophaga jacobsoni (RoHDEndoRF, 1937), H= Scatophaga litorea VILlEnEuVE, 1917, I= Scatophaga stercoraria (LinNAEUS, 1758) larvae and pupa, J= Rhegmoclematini gen. sp. and K= Spelobia luteilabris (RoNDANI, 1880) and $\mathrm{L}$ displays a maggot ball of a Calliphoridae species in an Upp plot of a non-planted experimental island after 14 days of decomposition. 
Our best fit manyglm model with Poisson error distribution showed that the probability of maggot species occurrence is mainly derived from the habitat zone where decomposition takes place (Res.Df=7, Df.diff=2, Deviance=1809.1, p=0.001). If divided into the plot types 'transplanted' and 'experimental island', dominant species probability switches: While in transplanted plots the occurrence of Scatophaga stercoraria diminish from pioneer zone to upper salt marshes (Figure 6, probability decrease of about 71\%), the probability of Hydrotea dentipes occurrence strongly increases (about 41\%). In parallel, the amount of pioneer zone species increases from three to 10 species. In island plots, Hydrotaea dentipes is the most probable species to find in the pioneer zone (63.22\%). The occurrence probability of this species is decreasing into terrestrial direction.

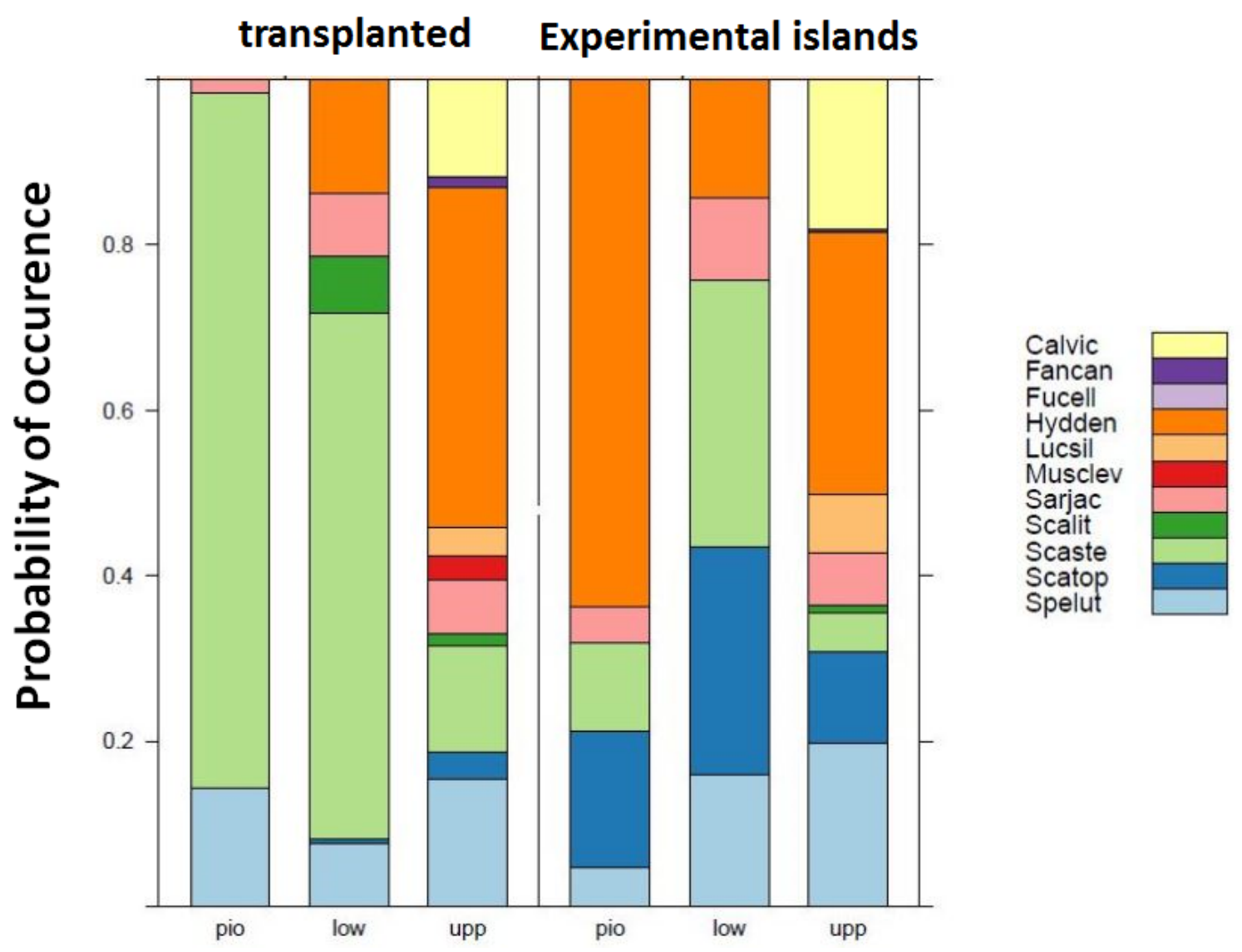

Figure 6 Standardized proportion of species occurrence of 11 most abundant decomposition related maggot species on all experimental plots. A significant difference between marine influenced pioneer zone communities and terrestrial associated maggot communities could be observed (manyglm, Deviance=1809.1, $\mathrm{p}=0.001$ ) as well as an effect between plot types (Deviance=1059.5, $\mathrm{p}=0.001$ ). Calvic= Calliphora vicina, Fancan=Fannia caniculairs, Fucell= Fucellia tergina, Hydden= Hydrotaea dentipes, Lucsil= Lucilia silvarum, Musclev= Muscina levida, Sarjac= Sarcophaga jacobsoni, Scalit= Scatophaga litorea, Scaste $=$ S. stercoraria , Scatop $=$ Rhegmoclematini gen. $s p$. And Spelut $=$ Spelobia luteilabris. A significant 
community shift could be observed in the three most abundant maggot species Scatophaga stercoraria, Hydrotaea dentipes and Spelobia luteilabris. In transplanted plots, probability of Scatophaga-occurrence decreases, where proportion of Hydrotaea and Spelobia increase.

A similar picture is drawn when plots are separated into planted and non-planted plots: In non-planted plots the probability of Hydrotaea dentipes occurrence is increasing (about 30\%), where Scatophaga stercoraria is most abundant in lower salt marsh plots and slightly diminishing in upper salt marshes (decrease of about 61\%). In planted plots, Scatophaga stercoraria is most probable to find in pioneer zone plots (probability of 88\%) and diminishing in a terrestrial direction (decrease of $80 \%$ ). The occurrence probability of Hydrotaea again drives into the other direction (Figure 6, probability increase of 48\%). For Spelobia luteilabris, occurrence probability both increases over salt marsh zonation for experimental islands (15\%) and planted plots (5\%). In transplanted plots as well as in planted plots, the probability in lower salt marsh is lowest compared to pioneer zone or upper salt marsh. Other species are only slightly or insignificantly increasing if at all.

In comparison with two other models (maggot abundance and abundance of the three most abundant maggot species), AICc of the species richness linear mixed effect models fit the best (AICc=1349.65). Our model highlighted maggot SR as main explanatory variable $(\mathrm{DF}=275, \mathrm{t}=-3.835, \mathrm{p}<0.001)$ and maggot abundance as second model $(\mathrm{AICc}=1351.09)$. Considered fixed effects zone, plot and the interaction term of zone and plot are not significantly influencing soil C/N ratio (Figure 7). 

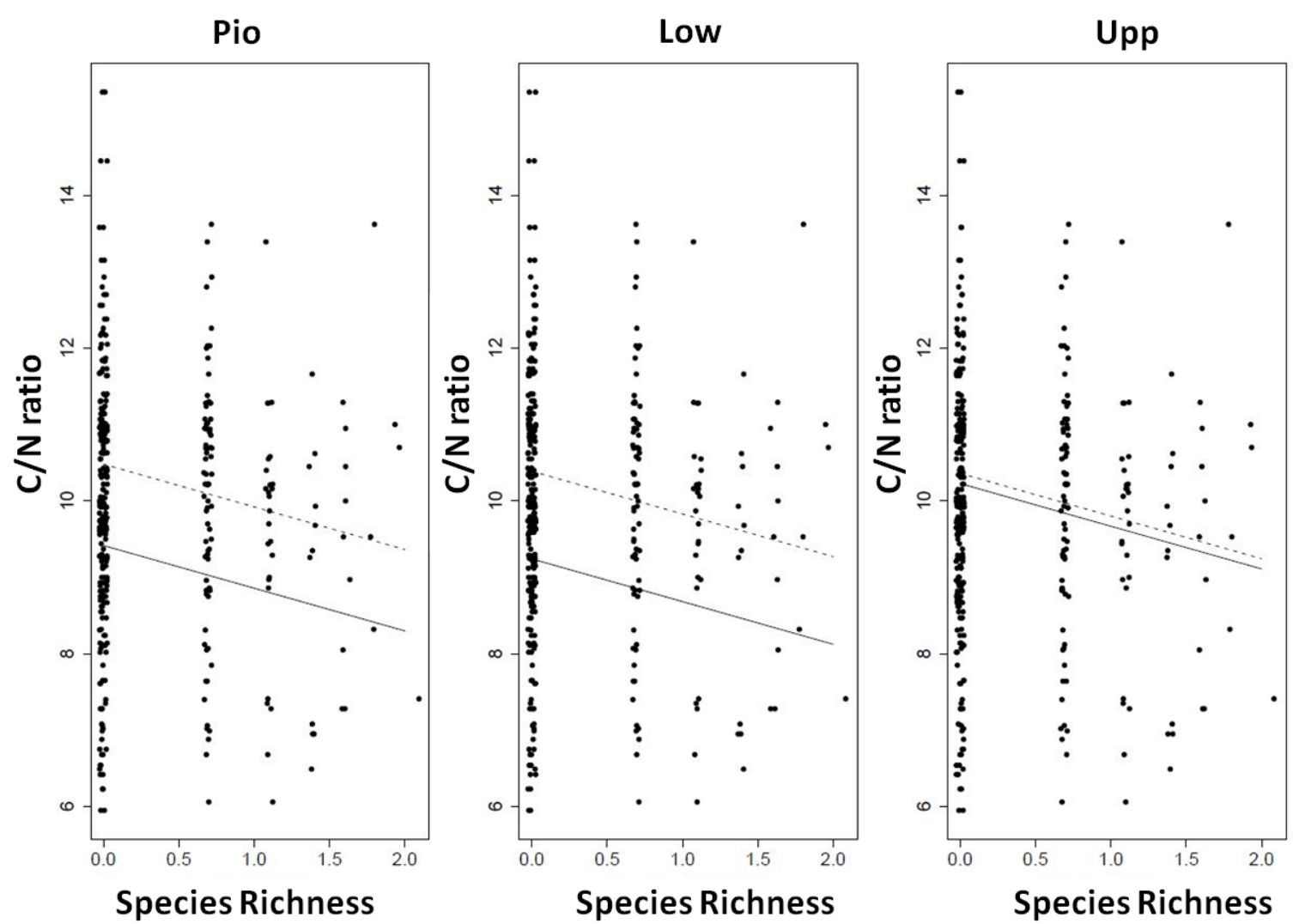

Figure 7 Predicted development of $\mathrm{C} / \mathrm{N}$ ratio from species richness of 11 most abundant maggot species. Our lme model display a highly significant negative effect of species richness on $\mathrm{C} / \mathrm{N}$ ratio $(\mathrm{Df}=$ 275, t-value=-3.835, p<0.001, transplanted=continuos line, experimental islands=dashed line).

\section{Discussion}

This study is among the first to unravel complex animal decomposition processes in a highly disturbed barrier island environment. Our results suggest that experimental plot identity (transplanted or experimental island), but not intertidal habitat zone, determines biomass loss during animal decay. In early successional habitats, represented by the experimental islands, animal decay was slower compared to transplanted plots. The decomposition process is mainly driven by eleven maggot species, three of which contribute the most (Table 2). In comparison to other experiments, which regularly have been conducted with whole carcasses from frog up to moose (Parmenter and MacMahon2009, Barton et al. 2013, Barton 2016) in terrestrial experiments, maggots have the most important impact on meat decay. Our experiment took place in autumn, when population sizes of beetles might have been low, while fly populations still occurred in large numbers. This is in accordance with a few published 
studies (Farwig, Brandl, Siemann, Wiener, \& M??ller, 2014), where fly maggots had the highest impact on animal decay compared to other decay-related taxa. Our observations focused on the decay of soft tissue - which allows the steepest biomass reduction per time (Parmenter and MacMahon 2009). Our results exhibited very large, max. 80\% biomass loss in upper salt marsh SM plots within 14 days of decay. As transplanted plots represent continuous habitat zones, biomass loss was most strongly in the terrestrial upper salt marsh plots than in pioneer zone plots. Pioneer zone and lower salt marshes are very similar in their amount of biomass loss over time compared to the upper salt marsh system. This could be explained by inundation events and the conserving effect of salt water in high tide times (Ayers 2000, Gómez et al. 2016). In our more isolated experimental island plots, no significant differences can be observed between habitat zones. As habitat fragmentation (isolation) leads to biodiversity loss (Tscharntke et al. 2002, Didham 2010, Krauss et al. 2010, Isbell 2015) and simplification of food webs, decomposition processes could then be reduced directly or indirectly (Haddad et al. 2015). Our analyses suggest that experimental disturbance resulting from habitat isolation, (e.g. higher sun exposition, higher amount of soil drying) may strongly influence ecosystem functions such as decomposition. Other studies demonstrate that in smaller fragments, ecosystem functions can be disturbed (Rosetti et al. 2017) and key ecosystem functions decrease via decreasing biomass and altering nutrient cycling over time (Haddad et al. 2015).

Although our experiment is set on the edge between terrestrial and marine habitats, the occurrence of animal decomposition related taxa is similar to terrestrial studies (Parmenter and MacMahon 2009, Farwig et al. 2014, Figure 4). Where terrestrial decomposing communities transform carcasses within several weeks or months and nutrients are rapidly recycled by primary producers (Payne and Moore 2006), the interplay of marine zones and primary productivity takes much more time (Beasley, Olson and DeVault 2012). In our setting, orders like Acari , Brachycera, Coleoptera and Collembola have been found on and beneath our experimental carcass setting. As a special taxon for marine habitats, also amphipods (Crustacea) occurred, but had no significant influence. During our observations, carcass dwelling maggot species had the highest abundance (Figure 4). Community structure of maggots differed between our plot settings: Hydrotaea dentipes, Scatophaga stercoraria and Spelobia luteilabris emerged as the most abundant species and competed along our marine-terrestrial 
gradient (Figure 6). Whereas Scatophaga stercoraria was the most abundant species in the pioneer zone, the proportion of occurrence along a terrestrial gradient changed to higher proportions of Hydrotaea dentipes. On the other hand, Spelobia luteilabris seemed to maintain in its proportion in all zones. Interestingly, both $H$. dentipes and $S$. stercoraria are not obligate carcass related fly taxa and seemed to accidently colonize our carcasses (Skidmore 1985, Smith 1989). Due to their commonly colonized substrate, S. stercoraria maggots are solitary individuals which could stick inside a cowpat for hours due to their ability of shutting down their spiracles (Smith 1989). This could be one aspect, why they could successfully maintain highest proportion in the pioneer zone. In comparison, Hydrotaea dentipes are normally developing in rotten plant detritus and are forming maggot balls from the second and third larval instar on. Ball formation has an interspecific outcompeting effect on other species and additionally protects the best tissue for maggots by local heat production and local production of species specific toxins (Skidmore 1985). As $H$. dentipes could not stand daily tidal events by shutting down their spiracles for a longer period of time, their strategy could only in more terrestrial habitats.

Our results support aspects of the trophic theory of island biogeography (TTIB). According to Gravel and colleagues (2011), predatory species display a broader range of trophic diets on small islands (in their study: Adirondack lakes, Canada) compared to larger islands. Besides the focus on predatory species, our results support that also on a decomposer level, trait based TTIB could influence species distribution. Instead of a food resource that has to be hounded by predators we displayed a short time occurring food resource which is more easily accessible for several species. In comparison, our experimental island plots displayed smaller and isolated islands. On the experimental islands, the proportion of $S$. stercoraria was much smaller compared with transplanted plots - in contrast, Hydrotaea dentipes had a larger proportion of occurrence in experimental island plots. Additionally, the dung midge Rhegmoclematini gen. sp. was only slightly present on salt marsh plots, whereas on experimental island plots, they occurred in much higher numbers (Figure 6). Looking at the trophic scale, both Hydrotaea dentipes and Rhegmoclematini gen. sp. have a broad range of feeding substrates (e.g. dung, carcasses, decaying plant material, Skidmore 1985, Haenni \& Vaillant 1994, Gill 2005, Haenni 2009), whereas Scatophaga stercoraria is only recorded from dung (Smith 1989, Skidmore 1991). According to published literature (Gravel 
2011, Jacquet et al. 2017, Massel 2017), this appears to support the assumption that species with a broader range of trophic substrates colonize smaller island patches more easily than species with a smaller trophic range.

Our study provides evidence that animal decay as an important ecosystem function should be considered in nature conservation measures. Until now, due to risk of botulism, large decaying animals (mammals, birds) are taken from conservation areas when they easily could be accessed by tourists, children or pets. Animal decomposition enhances local biodiversity and could therefore been understood as important process to maintain, for instance, specific fly species such as Scatophaga litorea or Scatopse litorea. Decomposition processes and local biodiversity enhancement stabilize other ecosystem functions (Eisenhauer and Schädler 2011) and play therefore an important role in the protection of habitats. Therefore, it might be possible, to protect humans and pets from the risk of infections, but also surround decaying animals by broad-meshed fence - decomposing species could still access decaying tissue but is separated from unwanted human access.

In conclusion, our experiment demonstrated that nutrient release following animal decomposition depends on species richness of decomposing maggots and, to a lesser degree, on plot identity.

\section{References}

Anderson, G. S., \& Bell, L. S. (2016). Impact of marine submergence and season on faunal colonization and decomposition of pig carcasses in the salish sea. PLOS ONE, 11(3). http://doi.org/10.1371/journal.pone.0149107

Bährmann, R. (2008). Bestimmung wirbelloser Tiere (4th ed., Vol. 5). Munich: Elsevier. http://doi.org/10.1007/978-3-642-55395-0

Balke, T., Lohmus, K., Hillebrand, H., Zielinski, O., Haynert, K., Meier, D., Hodapp, D. , Minden, V. anf Kleyer, M. (2017). Experimental salt marsh islands: a model system for novel metacommunity experiments. (In press.).

Barton, P. S., Cunningham, S. A., Macdonald, B. C. T., McIntyre, S., Lindenmayer, D. B., \& Manning, A. D. (2013). Species Traits Predict Assemblage Dynamics at Ephemeral Resource Patches Created by Carrion. PLoS ONE, 8(1). http://doi.org/10.1371/journal.pone.0053961

Borda-de-Água, L., Whittaker, R. J., Cardoso, P., Rigal, F., Santos, A. M. C., Amorim, I. R., ... Borges, P. a. V. (2017). Dispersal ability determines the scaling properties of species 
abundance distributions: a case study using arthropods from the Azores. Scientific Reports, 7(1), 3899. http://doi.org/10.1038/s41598-017-04126-5

Bröring, U. (2009). Systematic and Biogeographical Account of the Midges and Flies ( Diptera ) of the East Frisian Islands. BTU Cottbus, LS Allgemeine Ökologie, Printed $d r$, $1-17$.

Charbonneau, B. R., Wootton, L. S., Wnek, J. P., Langley, J. A., \& Posner, M. a. (2017). A species effect on storm erosion: Invasive sedge stabilized dunes more than native grass during Hurricane Sandy. Journal of Applied Ecology, 1385-1394. http://doi.org/10.1111/1365-2664.12846

Dunger, W., \& Fiedler, H. J. (1999). Methoden der Bodenbiologie BESTIMMUNGSTAFELN. (H. Friedler \& W. Dunger, Eds.) (2nd ed.). Jena: Gustav-Fischer-Verlag.

Farwig, N., Brandl, R., Siemann, S., Wiener, F., \& Mueller, J. (2014). Decomposition rate of carrion is dependent on composition not abundance of the assemblages of insect scavengers. Oecologia, 175(4), 1291-1300. http://doi.org/10.1007/s00442-0142974-y

Folmer, O., Black, M., Hoeh, W., Lutz, R., \& Vrijenhoek, R. (1994). DNA primers for amplification of mitochondrial cytochrome c oxidase subunit I from diverse metazoan invertebrates. Molecular Marine Biology and Biotechnology, 3(5), 294299. http://doi.org/10.1371/journal.pone.0013102

Foster, T. E., Stolen, E. D., Hall, C. R., Schaub, R., Duncan, B. W., Hunt, D. K., \& Drese, J. H. (2017). Modeling vegetation community responses to sea-level rise on Barrier Island systems: A case study on the Cape Canaveral Barrier Island complex, Florida, USA. PLoS ONE, 12(8), 1-22. http://doi.org/10.1371/journal.pone.0182605

Garb, J. E., \& Gillespie, R. G. (2006). Island hopping across the central Pacific: mitochondrial DNA detects sequential colonization of the Austral Islands by crab spiders (Araneae: Thomisidae). Journal of Biogeography, 33(2), 201-220. http://doi.org/10.1111/j.1365-2699.2005.01398.x

Goodman, K. R., \& O’Grady, P. (2013). Molecular Phylogeny and Biogeography of the Hawaiian Craneflies Dicranomyia (Diptera: Limoniidae). PLoS ONE, 8(9). http://doi.org/10.1371/journal.pone.0073019

Gravel, D., Massol, F., Canard, E., Mouillot, D., \& Mouquet, N. (2011). Trophic theory of island biogeography. Ecology Letters, 14(10), 1010-1016. http://doi.org/10.1111/j.1461-0248.2011.01667.x

Hadziavdic, K., Lekang, K., Lanzen, A., Jonassen, I., Thompson, E. M., \& Troedsson, C. (2014). Characterization of the 18s rRNA gene for designing universal eukaryote specific primers. PLoS ONE, 9(2). http://doi.org/10.1371/journal.pone.0087624

Hall, T. a. (1999). BioEdit: a user-friendly biological sequence alignment editor and analysis program for Windows 95/98/NT. Nucleic Acids Symposium Series. http://doi.org/citeulike-article-id:691774 
Hayes M.O. (1979). Barrier island morphology as a function of tidal and wave regime. In Leatherman S.P. [ed.], Barrier Islands. Academic Press, New York, pp. 1-27., (July).

Heaney, L. R. (2000). Dynamic disequilibrium: a long-term, large-scale perspective on the equilibrium model of island biogeography. Global Ecology and Biogeography, 9(1), 59-74. http://doi.org/10.1046/j.1365-2699.2000.00163.x

Heydemann, B. (n.d.). Heydemann (1967)_Der Ueberflug von Insekten ueber Nord- und Ostsee nach Untersuchungen auf Feuerschiffen.pdf.

Jacquet, C., Mouillot, D., Kulbicki, M., \& Gravel, D. (2017). Extensions of Island Biogeography Theory predict the scaling of functional trait composition with habitat area and isolation. Ecology Letters, 20(2), 135-146. http://doi.org/10.1111/ele.12716

Kotze, D. J., Niemelä, J., \& Nieminen, M. (2000). Colonization success of carabid beetles on Baltic islands. Journal of Biogeography, 27(4), 807-819. http://doi.org/10.1046/j.1365-2699.2000.00456.x

Losos, J. B., Warheitt, K. I., \& Schoener, T. W. (1997). Adaptive differentiation following experimental island colonization in Anolis lizards. Nature. http://doi.org/10.1038/387070a0

MacArthur, R., \& Wilson, E. O. (1967). The theory of island biogeography (13th ed.). Princeton: Princeton University Press.

Marcelino, J. A. P., Giordano, R., Borges, P. A. V., Garcia, P. V., Soto-Adames, F. N., \& Soares, A. 0. (2016). Distribution and genetic variability of staphylinidae across a gradient of anthropogenically influenced insular landscapes. Bulletin of Insectology, 69(1), 117-126.

Mondor, E. B., Tremblay, M. N., \& Messing, R. H. (2007). Morphological and ecological traits promoting aphid colonization of the Hawaiian Islands. Biological Invasions, 9(1), 87-100. http://doi.org/10.1007/s10530-006-9010-z

Oosterbroek, P. (2007). The European families of the Diptera. Identification, diagsnosis, biology, 205. http://doi.org/1

Parmenter, R. R., \& MacMahon, J. A. (2009). Carrion decomposition and nutrient cycling in a semiarid shrub- steppe ecosystem. Ecological Monographs, 79(4), 637-661. http://doi.org/10.1890/08-0972.1

Pedley, S. M., \& Dolman, P. M. (2014). Multi-taxa trait and functional responses to physical disturbance. Journal of Animal Ecology, 83(6), 1542-1552. http://doi.org/10.1111/1365-2656.12249

Raposeiro, P. M., Costa, A. C., \& Hughes, S. J. (2011). Environmental factors - spatial and temporal variation of chironomid communities in oceanic island streams (Azores archipelago). Annales de Limnologie - International Journal of Limnology, 47(4), 325-338. http://doi.org/10.1051/limn/2011048 
Rejmánek, M., Richardson, D. M., Barbour, M. G., Crawley, M. J., Hrusa, F. G., Moyle, P. B., ... Williamson, M. (2002). Biological invasions: politics and the discontinuity of ecological terminology. Bulletin of the Ecological Society of America, 131-133.

Reynolds, A. M., Bohan, D. a, \& Bell, J. R. (2007). Ballooning dispersal in arthropod taxa: conditions at take-off. Biology Letters, 3(3), 237-40. http://doi.org/10.1098/rsbl.2007.0109

Richards, S. L., Connelly, C. R., Day, J. F., \& Hope, T. (2015). Arthropods associated with carrion in a salt marsh habitat in southeastern Florida. Florida Entomologist, 98(2), 613-619. http://doi.org/10.1653/024.098.0234

Rose, A., Bellmann, A., Büche, B., Esser, J., Maus, C., \& Renner, K. (2006). Kurzflügelkäfer der Ostfriesischen Inseln : unpublizierte Funde , Funddaten sowie Korrekturen ( Coleoptera , Staphylinidae: excl. Aleocharinae)-1.Teil. Drosera, 129-156.

Rose, A., \& Möhlmann, G. (1993). Zur Besiedlung der jungen Düneninsel Mellum durch Staphyliniden (Coleoptera: Staphylinidae). Drosera, 93(1), 101-123.

Rosenzweig, M. L. (1995). Species diversity in space and time (1st ed.). Cambridge: University of Cambridge Press.

Simberloff, D. S., \& Wilson, E. O. (1969). Experimental Zoogeography of Islands : The Colonization of Empty Islands Author ( s ): Daniel S. Simberloff and Edward 0 . Wilson Published by: Wiley on behalf of the Ecological Society of America Stable URL : http://www.jstor.org/stable/1934856 REFEREN, 50(2), 278-296.

Simberloff, D. S., \& Wilson, E. O. (1970). Experimental Zoogeography of Islands. A TwoYear Record of Colonization. Ecology, 51(5), 934-937.

Stutz, M. L., \& Pilkey, O. H. (2011). Open-ocean barrier islands: Global influence of climatic, oceanographic, and depositional settings. Journal of Coastal Research, 27(2), 207-222. http://doi.org/10.2112/09-1190.1

Szpila, K. (2010). Current concepts in forensic entomology. (J. Amendt, M. L. Goff, C. P. Campobasso, \& M. Grassberger, Eds.), Key for the Identification of Third Instars of European Blowflies (Diptera: Calliphoridae) of Forensic Importance (1st ed.). Heidelberg: Springer Verlag. http://doi.org/10.1007/978-1-4020-9684-6_3

Szpila, K. (2010). Key for the identification of third instars of european blowflies (Diptera: Calliphoridae) of forensic importance. Current Concepts in Forensic Entomology, 43-56. http://doi.org/10.1007/978-1-4020-9684-6_3

Szymkowiak, P., Górski, G., \& Bajerlein, D. (2007). Passive dispersal in arachnids. Biological Lett, 44(2), 75-101. Retrieved from www.biollett.amu.edu.pl

Tabor, K. L., Brewster, C. C., \& Fell, R. D. (2004). Analysis of the Successional Patterns of Insects on Carrion in Southwest Virginia. Journal of Medical Entomology, 41(4), 785-795. http://doi.org/10.1603/0022-2585-41.4.785 
Udy, K. L., Fritsch, M., Grass, I., Hartig, F., Kneib, T., Kreft, H., ... Wiegand, K. (n.d.). Environmental heterogeneity predicts global species richness better than area, 125.

Weigelt, P., Jetz, W., \& Kreft, H. (2013). Bioclimatic and physical characterization of the world's islands. Proceedings of the National Academy of Sciences of the United States of America, 110(38), 15307-12. http://doi.org/10.1073/pnas.1306309110

Wu, Z., Li, Y., \& Murray, B. R. (2006). Insular shifts in body size of rice frogs in the Zhoushan Archipelago, China. Journal of Animal Ecology, 75(5), 1071-1080. http://doi.org/10.1111/j.1365-2656.2006.01126.x

Yang, L. H., Bastow, J. L., Spence, K. O., \& Wright, A. N. (2008). What can we learn from resource pulses? Ecology, 89(3), 621-634. http://doi.org/10.1890/07-0175.1

Yoshimoto, B. C. M., Gressitt, J. L., \& Mitchell, C. J. (1962). TRAPPING OF AIR-BORNE INSECTS IN THE PACIFIC- ANTARCTIC AREA , 1. Pacific Insects, 4(4), 847-858.

Zabka, M., \& Nentwig, W. (2000). Salticidae (Arachnida: Araneae) of the Krakatau Islands (Indonesia) - A preliminary approach. Ekologia Bratislava, 19(9993), 293-306. 
SUPPORTING INFORMATION

Chapter 4 
Table S1 Soil extraction protocol changes following Kempson, Lloyd and Ghelardi 1963

$\begin{array}{lll}\text { day } & \begin{array}{l}\text { temperature } \\ {\left[{ }^{\circ} \mathbf{C}\right]}\end{array} & \begin{array}{l}\text { duration } \\ {[\mathbf{h}]}\end{array} \\ 1 & 25 & 24 \\ 2 & 30 & 24 \\ 3 & 35 & 24 \\ 4 & 40 & 24 \\ 5 & 45 & 24 \\ 6 & 50 & 24 \\ 7 & 55 & 24 \\ 8 & 55 & 24\end{array}$

Text S2 Complete barcoding protocol.

\section{DNA extraction}

DNA from samples was extracted using the DNeasy Blood \& Tissue Kit (Qiagen). At first, samples were weighted and a maximum of $50 \mathrm{mg}$ of each sample (larva, pupa or imago) were transferred at a $2 \mathrm{ml}$ microcentrifuge tube (Eppendorf) and homogenized with a glass mortar in $180 \mu \mathrm{l}$ PBS buffer. Samples weighting more than 50 mg were cut with a scalpel. When cutting imagines, only the thorax was used. Afterwards, $20 \mu$ Proteinase $\mathrm{K}$ (Qiagen) and $200 \mu \mathrm{l} \mathrm{AL}$ buffer were added, vortexed thoroughly and incubated for $10 \mathrm{~min}$ at $56^{\circ} \mathrm{C}$. Not fully dissolved samples were incubated for another $10 \mathrm{~min}$. After incubation $200 \mu \mathrm{l}$ ethanol (96-100\%) were added and vortexed thoroughly. Subsequently, mixture was pipetted into the DNeasy Mini spin column placed in a $2 \mathrm{ml}$ collection tube and centrifuged for $1 \mathrm{~min}$ at 8,000 rpm. Flow-through and collection tube were discarded. The columns were placed in a new collections tube and $500 \mu \mathrm{l}$ Buffer 
AW1 were added and centrifuged for $1 \mathrm{~min}$ at 8,000 rpm. The columns were placed again in new collection tubes and $500 \mu$ l Buffer AW2 were added and centrifuged for $3 \mathrm{~min}$ at 13,200 rpm. Flow-through and provided collection tubes were discarded after each step. At last, the columns were placed in a $2 \mathrm{ml}$ microcentrifuge tube and $50 \mu \mathrm{l}$ Buffer AE were pipetted directly at the center of the membrane, incubated for 5 min at room temperature and centrifuged for $1 \mathrm{~min}$ at 8,000 rpm. Flow-through and columns were discarded and eluted DNA is stored at $-20^{\circ} \mathrm{C}$.

Because the samples for Hydrotaea dentipes, Nemotelus notatus, Haematopota pluvialis and an unidentified pupa (pupa1) were small, inset of chemicals were cut in half to ensure a possible higher concentration of DNA at the second extraction.

\section{PCR}

The PCR was used to amplify a 730 bp sequence from the COI region. The primer pair was modified after universal primers LCO1490 (up) and HCO2198 (low) (Folmer, Black, Hoeh, Lutz, \& Vrijenhoek, 1994) and can be seen in Table 1. When COI primers showed no success, modified $18 \mathrm{~S}$ primers (after Hadziavdic et al., 2014) were used for amplification (Table 1).

PCR amplifications were carried out in a final reaction volume of $25 \mu \mathrm{l}$ consisting of $1 \mu \mathrm{l}$

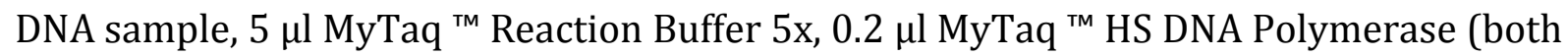
Bioline), $1 \mu \mathrm{l}$ of a $20 \mu \mathrm{M}$ working solution of forward and reverse Primer and $16.8 \mu \mathrm{l}$ of RNase free Water (Qiagen). PCR was performed on a DNA Thermal Cycler type Mastercycler ${ }^{\circledR}$ Personal (Eppendorf) using the followings conditions for COI PCR: $95^{\circ} \mathrm{C}$ for $5 \mathrm{~min}$ and $30 \mathrm{cycles}$ of $94^{\circ} \mathrm{C}$ for $1 \mathrm{~min}, 55^{\circ} \mathrm{C}$ for $1 \mathrm{~min}$ and $72^{\circ} \mathrm{C}$ for $1 \mathrm{~min}$. Annealing temperature was adjusted to $51^{\circ} \mathrm{C}$ and $48^{\circ} \mathrm{C}$, respectively for samples with no amplification success at $55^{\circ} \mathrm{C}$. Reamplification of PCR products used adjusted conditions of 20 cycles and $45^{\circ} \mathrm{C}$ annealing temperature. 18S PCR conditions used the same conditions, but $65^{\circ} \mathrm{C}$ annealing temperature. Amplification success was visualized via gel electrophoresis with 2\% (2.5\% respectively) agarose gel (110 V for $40 \mathrm{~min}$; Low Molecular Weight DNA Ladder (New England Biolabs Inc.). PCR products were purified using $7.5 \mu \mathrm{l}$ of PCR reactions $2.5 \mu \mathrm{l}(1 \mathrm{U})$ rAPid Alkaline Phosphatase Roche Inc.) and $1 \mu \mathrm{l}$ (1U) Exonuclease I (New England BiolabsInc), following by incubation at $37^{\circ} \mathrm{C}$ for $60 \mathrm{~min}$ and $75^{\circ} \mathrm{C}$ for $15 \mathrm{~min}$. Reamplification PCR products were purified using $5 \mu \mathrm{l}$ of 
PCR reaction and $2 \mu \mathrm{l}$ of ExoSAP-IT ${ }^{\circledR}$ Express (Affymetrix), following by incubation at $37^{\circ}$ for $4 \mathrm{~min}$ and $80^{\circ} \mathrm{C}$ for $1 \mathrm{~min}$.

\section{Sequencing}

Sequencing reactions were carried out with the BigDye® Terminator (BDT) v1.1 Cycle Sequencing Kit (Applied Biosystems). The final reaction volume was $20 \mu$ l consisting of $2 \mu \mathrm{l} \mathrm{BDT}, 4 \mu \mathrm{l}$ Seq Buffer (5x), $0.3 \mu \mathrm{l}$ of a $20 \mu \mathrm{M}$ working solution of the reverse COI and 18S Primer, respectively, $6.7 \mu \mathrm{H}_{2} \mathrm{O}$ and $7 \mu \mathrm{l}$ PCR product. ). Sequencing reactions (COI and 18S) were performed on a DNA Thermal Cycler type Mastercycler® (Eppendorf) using the followings conditions for COI PCR: $94^{\circ} \mathrm{C}$ for $3 \mathrm{~min}$ and 25 cycles of $94^{\circ} \mathrm{C}$ for $30 \mathrm{sec}, 50^{\circ} \mathrm{C}$ for $15 \mathrm{sec}$ and $60^{\circ} \mathrm{C}$ for $2.5 \mathrm{~min}$ and a final elongation step at $60^{\circ} \mathrm{C}$ for $4 \mathrm{~min}$. After that samples were cooled down to $10^{\circ} \mathrm{C}$. Sequencing products were purified using the NucleoSEQ® Kit (Macherey \& Nagel) following the manufacturer's instructions.

Capillary electrophoresis was performed on a 3500 Genetic Analyzer (Applied Biosystems) using POP-7 polymer in the capillary (36 cm array, Applied Biosystems), a customized run module and $20 \mu \mathrm{l}$ of the purified sequencing product. The sequences were analyzed using the software BioEdit v7.2.5 (Hall, 1999). 


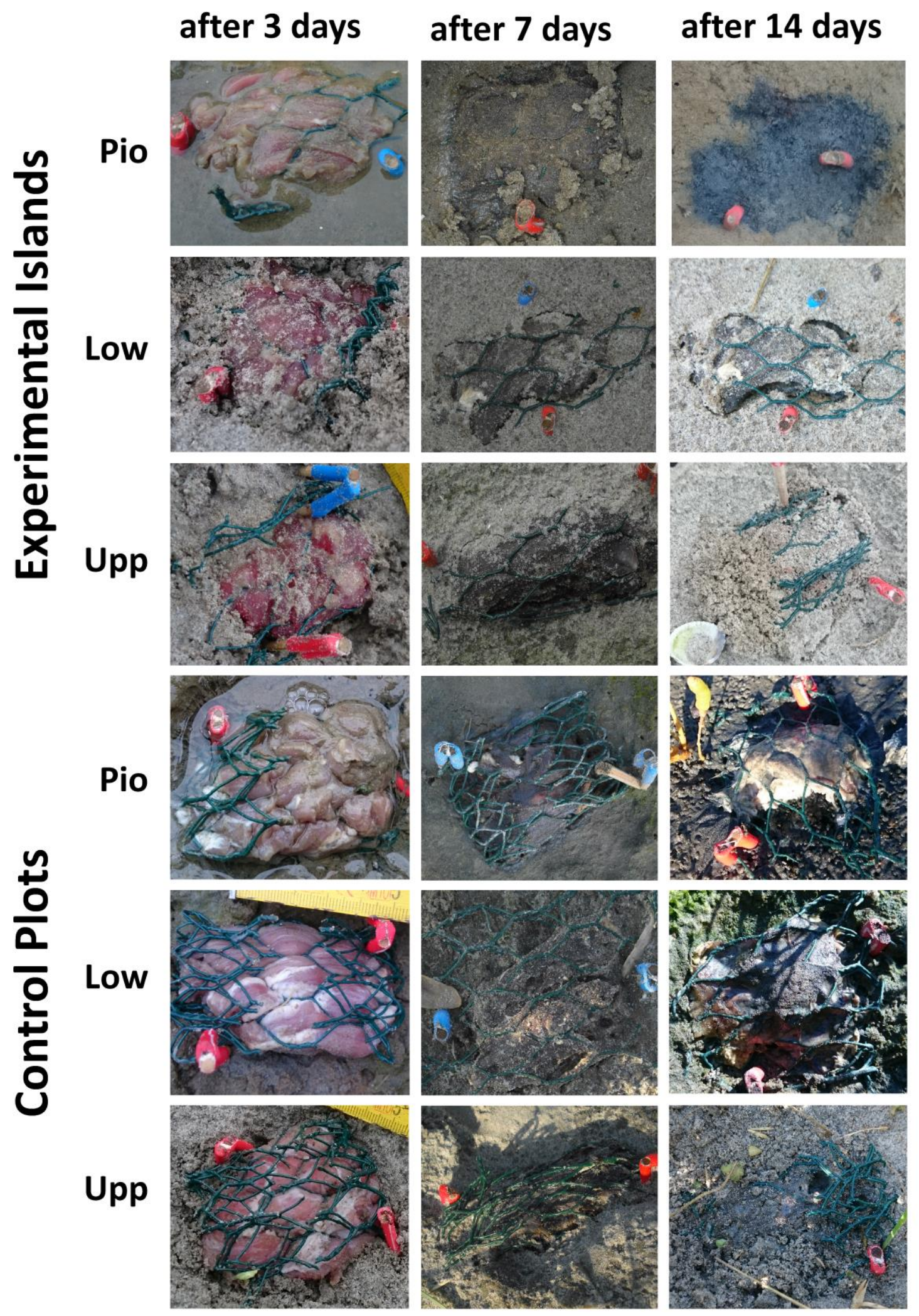

Figure S3 Non-planted plots of decomposition experiment. Decomposition of meat pieces is displayed as a timeline from left to right for the different treatments. Meat pieces of Experimental islands are strongly sedimented by sand over time. After 14 days of decay, soil microbial communities tend to change: In Experimental Island Pio plots, soil colour surrounding the meat changes from sandy to blackish indicating higher concentration of sulfur-reducing bacteria. Additionally, meat pieces of higher elevation 
(Low and Upp) tend to dry out immediately after explosion (see pictures after 7 days onwards). In transplanted experimental plots, high sedimentation rates only occur in Low plots after 7 days of decomposition. Holes in meat pieces of Low and Upp plots after 14 days of decay indicate strong maggot and beetle activity.

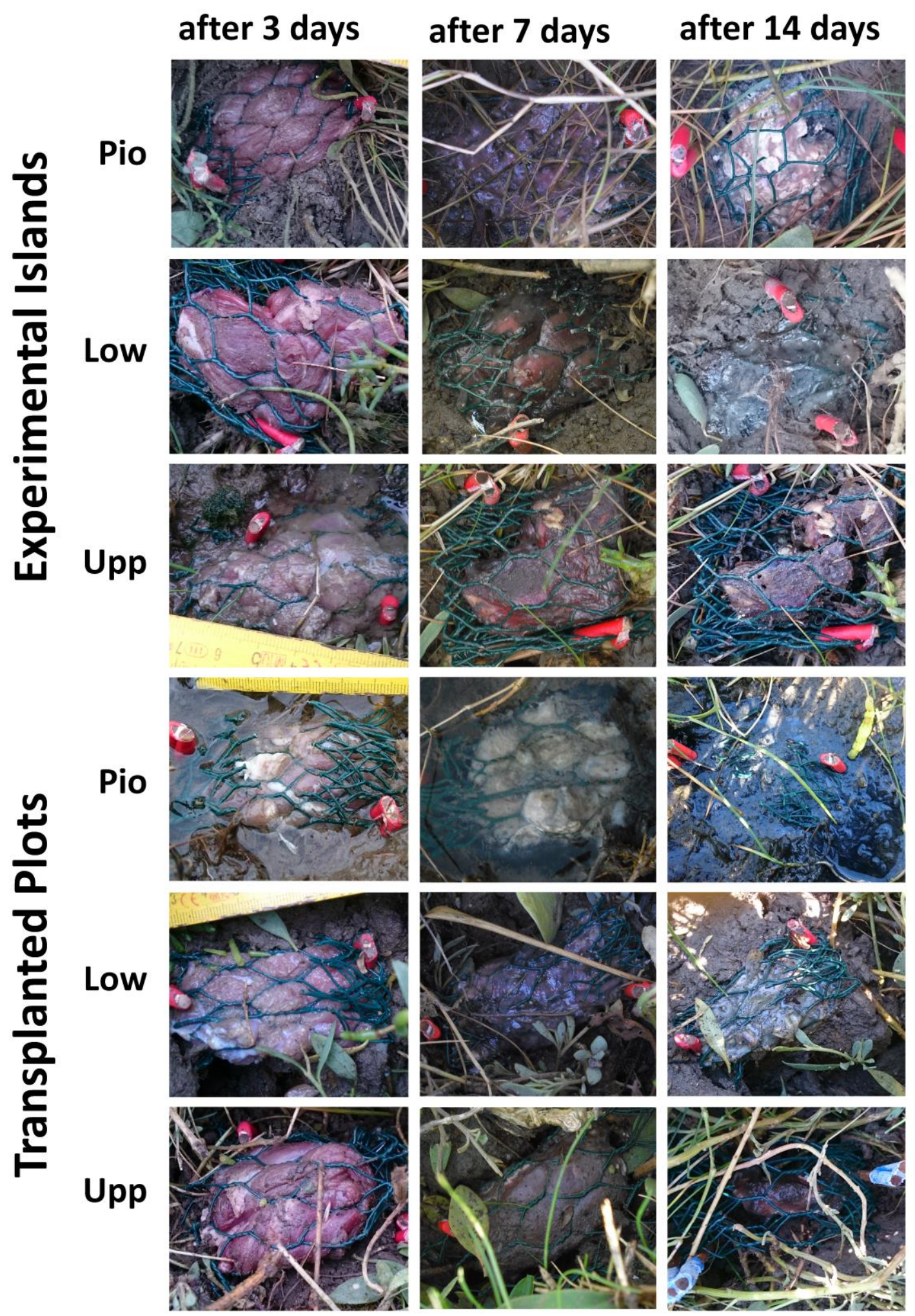


Figure S4 Planted plots of decomposition experiment. Decomposition of meat pieces is displayed is displayed as a timeline from left to right for the different treatments. In Pio plots, blood components are rapidly washed out resulting in a lighter meat color after 7 days. In transplanted plots, this effect can be seen the best here. Additionally, after 14 days in transplanted Pio plots, a microbial biofilm with blackish soil elements could be observed indicating that sulfur-reducing bacteria occur in the upper soil layer. In general, meat weight reduction can be observed from meat size: In Upp plots, meat sizes are visibly reduced compared to other plots. 


\section{APPENDIX}

\section{A1 - Complete R-Code for Chapter 4}

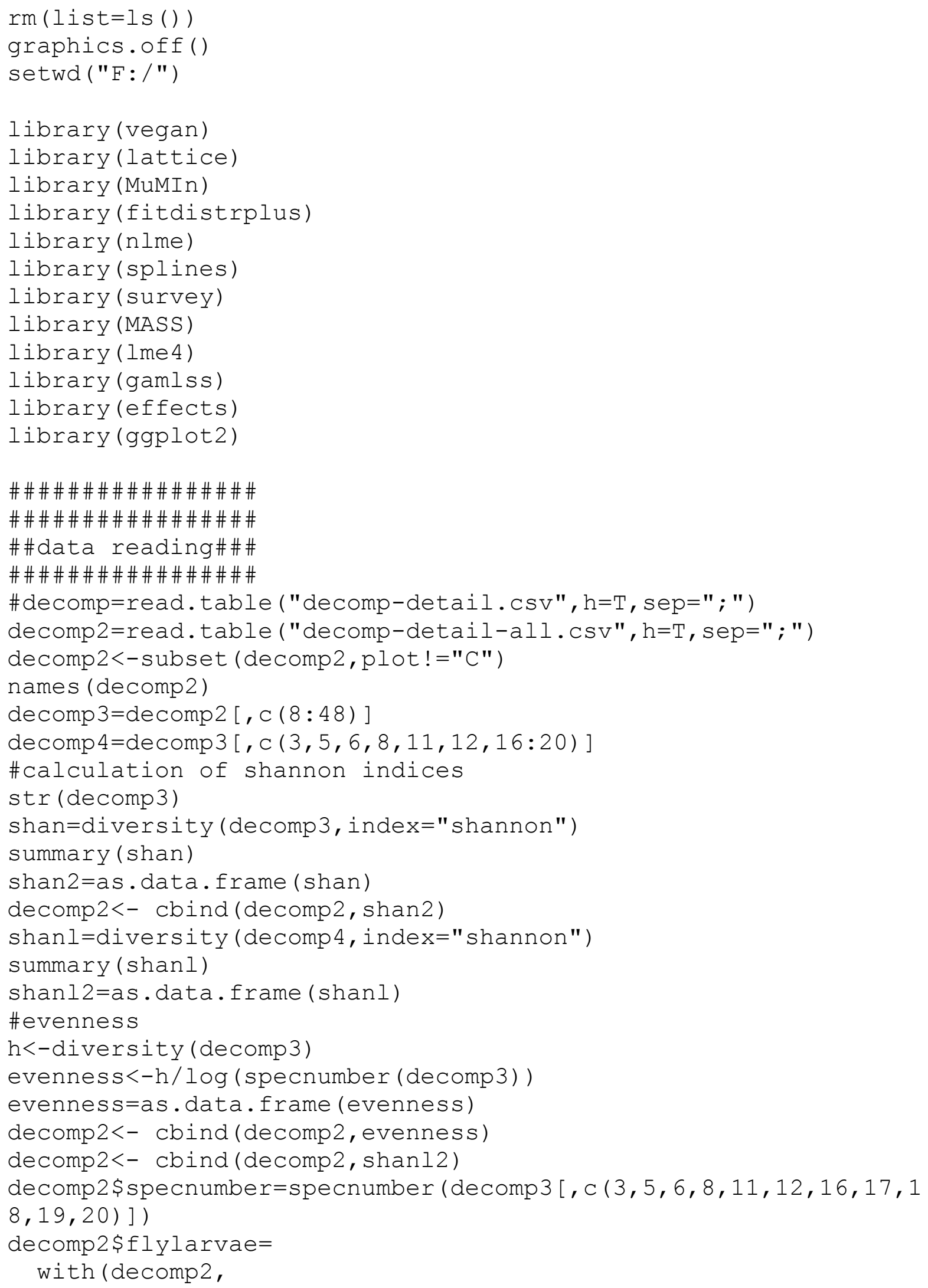


rowSums (cbind (Calvic, Fancan, Fucell, Hydden, Lucsil, Musclev, Sarja c, Scalit, Scaste, Scatop, Spelut)) )

decomp 2 \$roups=paste (decomp2\$plot, decomp2\$plants, sep="-")

decomp2\$weight2=decomp2\$weight $/ 7.763$

plotcodes=read.table ("Plots-sine-C.csv", $h=T, s e p=" ; ")$

decomp2=merge (decomp2, plotcodes, by=c ("no", "zone") )

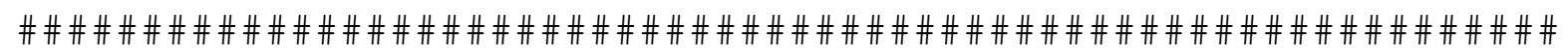

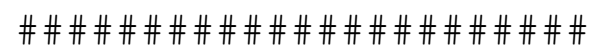

\#\#\#\#\#\#\#\#\#\#\#FIGURE 1 - weight loss per

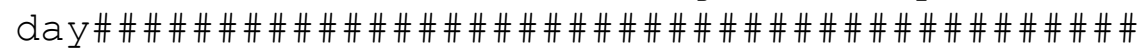

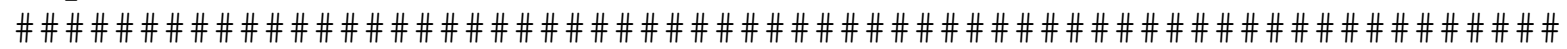

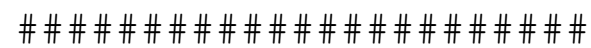

$\mathrm{n} 4 \mathrm{a}=\operatorname{lme}(\log ($ weight2 +1$) \sim$ day, random= $1 \mid$ plotcode/zone, decomp2, met hod="ML")

$\mathrm{n} 4=\operatorname{lme}\left(\log (\right.$ weight $2+1) \sim$ day $^{*}($ zone+plot $) \wedge 2$, random= $1 \mid$ plotcode $/$ zon e, decomp2, method="ML")

n5 $=$ stepAIC (n 4$)$

mylog=function $(x) \log (x+1)$

myexp=function $(x) \exp (x)-1$

plot (alleffects (n5, transformation=list ( 1 ink=mylog, inverse=myex p)),

multiline=T,ci.style="bands", type="response", $x l a b=" d a y$ of decomposition", ylab="Biomass $[\%] "$, layout $=c(3,1)$ )

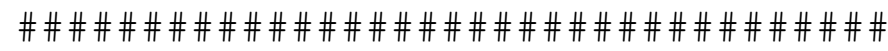
anova (n5)

$\begin{array}{lrrrr}\text { (Intercept) } & \text { numDF } & \text { denDF } & \text { F-value } & \text { p-value } \\ \text { day } & 1 & 372 & 1382.2362 & <.0001 \\ \text { zone } & 1 & 372 & 233.1504 & <.0001 \\ \text { plot } & 2 & 32 & 0.8900 & 0.4206 \\ \text { zone:plot } & 1 & 16 & 13.3183 & 0.0022 \\ \text { day: zone } & 2 & 32 & 3.9304 & 0.0298 \\ \text { day:plot } & 2 & 372 & 3.4671 & 0.0322 \\ \text { day:zone:plot } & 1 & 372 & 27.9105 & <.0001 \\ \text { datel } & 2 & 372 & 4.2055 & 0.0156\end{array}$

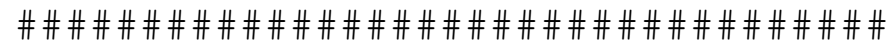

$>$ summary (n5)

Linear mixed-effects model fit by maximum likelihood

Data: decomp2
AIC
BIC $\quad \log L i k$

$-389.1336-328.1072 \quad 209.5668$

Random effects:

Formula: 1 | plotcode

(Intercept)

StdDev: 0.04793621 


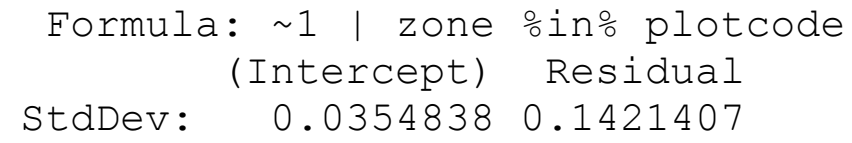

Correlation:

(Intr) day zonelw zonepp pltSMC znl:SMC znp:SMC dy:znl dy:znp dy:SMC dy:znl:SMC

day

zonelow

zoneupp

plotSMC

zonelow:plotSMC

zoneupp:plotSMC

day: zonelow

0.228

day: zoneupp

$0.455 \quad 0.500$

day:plot SMC

$\begin{array}{lll}0.483 & 0.471 & 0.471\end{array}$

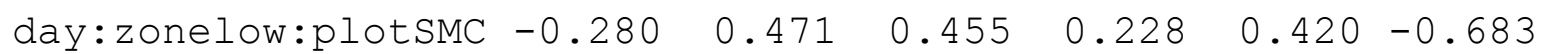

$-0.341-0.667-0.333-0.707$

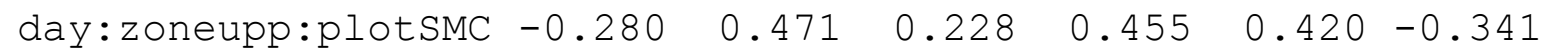
$\begin{array}{lllll}-0.683 & -0.333 & -0.667 & -0.707 & 0.500\end{array}$

$-0.593$

$-0.6150 .483$

$\begin{array}{lll}-0.615 & 0.483 & 0.500\end{array}$

$\begin{array}{llll}-0.667 & 0.396 & 0.410 & 0.410\end{array}$

$0.410-0.322-0.667-0.333-0.615$

$\begin{array}{llllll}0.410 & -0.322 & -0.333 & -0.667 & -0.615 & 0.500\end{array}$

$\begin{array}{lllllll}0.420 & -0.707 & -0.683 & -0.341 & -0.280 & 0.455\end{array}$

$\begin{array}{lllllll}0.420 & -0.707 & -0.341 & -0.683 & -0.280 & 0.228\end{array}$

$\begin{array}{lllllll}0.396 & -0.667 & -0.322 & -0.322 & -0.593 & 0.483\end{array}$ 
Standardized Within-Group Residuals:
Min
Q1
Med
Q3
$\operatorname{Max}$

$\begin{array}{llll}-2.72549378 & -0.55490511 & 0.02614686\end{array}$

$0.57852042 \quad 4.16574362$

Number of Observations: 432

Number of Groups:

plotcode zone oin\% plotcode

18

54

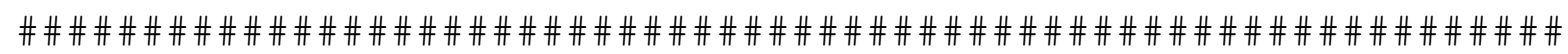

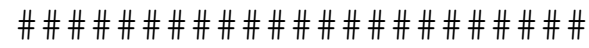

\#\#\#\#\#\#\#\#\#\#\#IGURE 2 - bar chart all taxa abundance over time in different zones\#\#

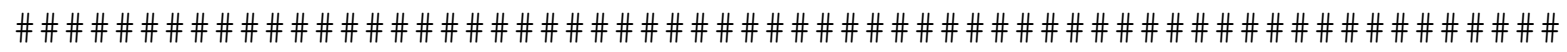

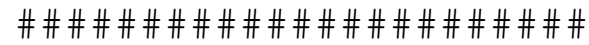

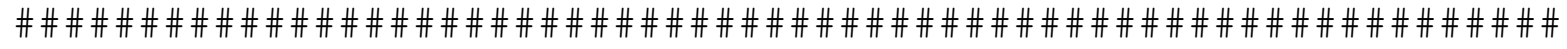
\# \# \# \# \# \# \# \# \# \# \# \# \# \# \#\# \# \# \# \# \# \# \# \# \# \# \#

\#\#\#\#\#\#\#\#\#\#\#IGURE 3 - bar chart probability of maggot

species per treatment/plot/zone\#\#

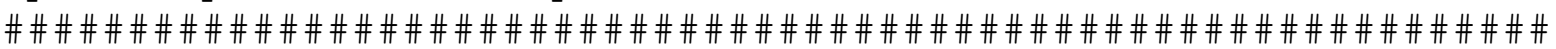
\# \# \# \# \# \# \# \# \# \# \# \# \# \# \# \# \# \# \# \# \# \# \# \# \# \# \#

mytimes=full4\$value

full4.long $<-$

as.data.frame (apply (full4, 2, function (x) rep (x,mytimes)), row.nam es=FALSE $)$

head (full4.long)

plot (full4.long\$value)

full4.long\$zone=ordered (full4. long\$zone, levels=c ("pio", "low"," upp") )

ful14.long\$plot=ordered (full4.long\$plot, levels=C ("SMC", "EI"))

full4.long\$variable=ordered (full4.long\$variable, levels=c ("Spel ut", "Scatop", "Scaste","Scalit","Sarjac",

"Musclev", "Lucsil", "Hydden", "Fucell", "Fancan", "Calvic"))

multl=multinom (variable plot*zone+plants+plants:zone, data=ful14.long, maxit=200, MaxNWts=1000, se=TRUE)

library (RColorBrewer)

library (car)

Anova (mult 1 )

summary (mult 1$)$

coef (mult 1$)$

head (fitted (mult 1 ))

plot (alleffects (mult1), style="stacked", key=list (columns=2),

color = brewer.pal (11, "Paired"))

\#\#\#\#related statistical background: manyglm!\#\# 
plot (alleffects (n17, transformation=list (link=mylog, inverse=mye xp)), type="response", ci.style="bands", multiline $=$ T)

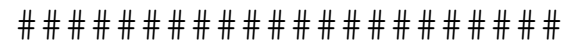

$\operatorname{aov}(n 17)$

Call:

aov (formula $=$ n17)

Terms:

$$
\text { weight2 zone plot plants }
$$

weight 2 :zone weight 2 :plot zone:plot weight $2:$ plants
Sum of Squares
3.23116
0.45727
0.12786
0.63623

0.14549 0.15127

5.56868

3. 89978

Deg. of Freedom 1 2

zone:plants plot:plants weight2:plot:plants zone:plot:plants Residuals

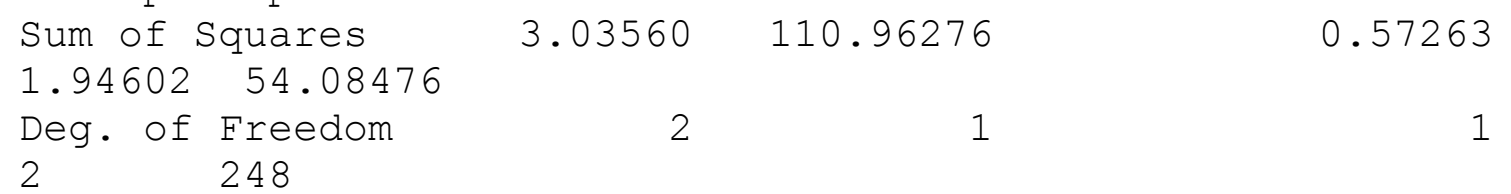

\footnotetext{
Residual standard error: 0.4669943

Estimated effects may be unbalanced

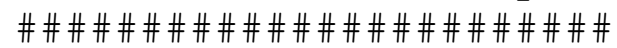

aov (formula $=$ n17)
}

Terms:

$$
\text { weight2 zone plot plants }
$$

weight2:zone weight2:plot zone:plot weight2:plants

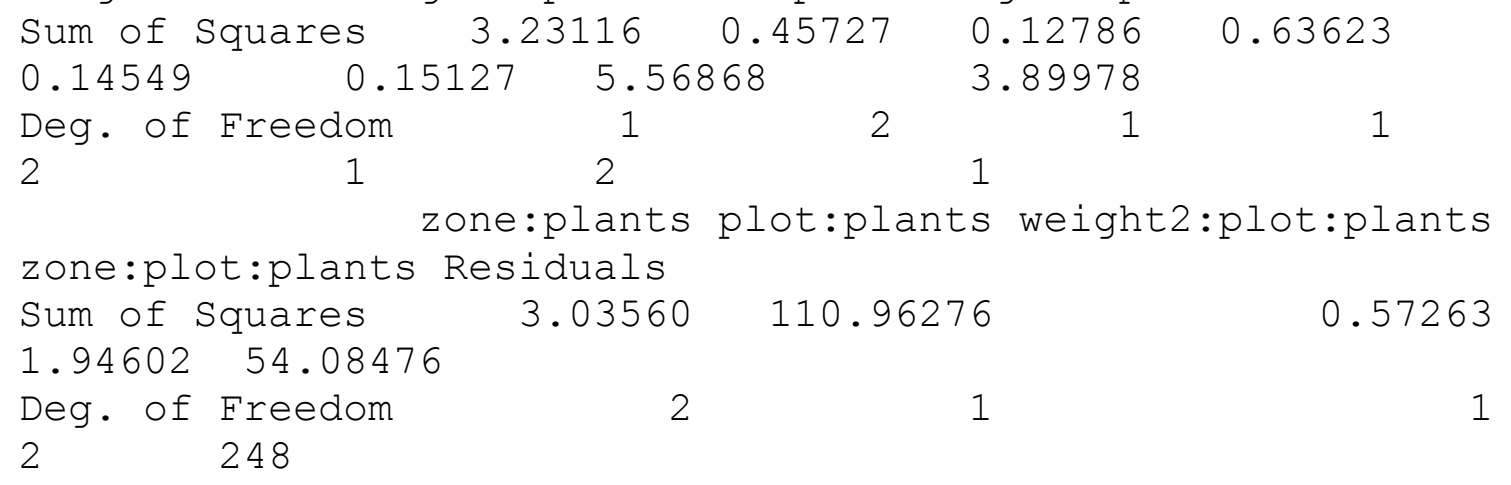

Residual standard error: 0.4669943

Estimated effects may be unbalanced

$>$ summary $(\mathrm{n} 17)$

Linear mixed-effects model fit by maximum likelihood

Data: decomp_p AIC BIC logLik

$370.347 \quad 445.6004-164.1735$

Random effects:

Formula: 1 | plotcode 
(Intercept)

StdDev: 2.876971e-05

Formula: 1 | zone oino plotcode

(Intercept) Residual

StdDev: $\quad 0.12521130 .4340517$

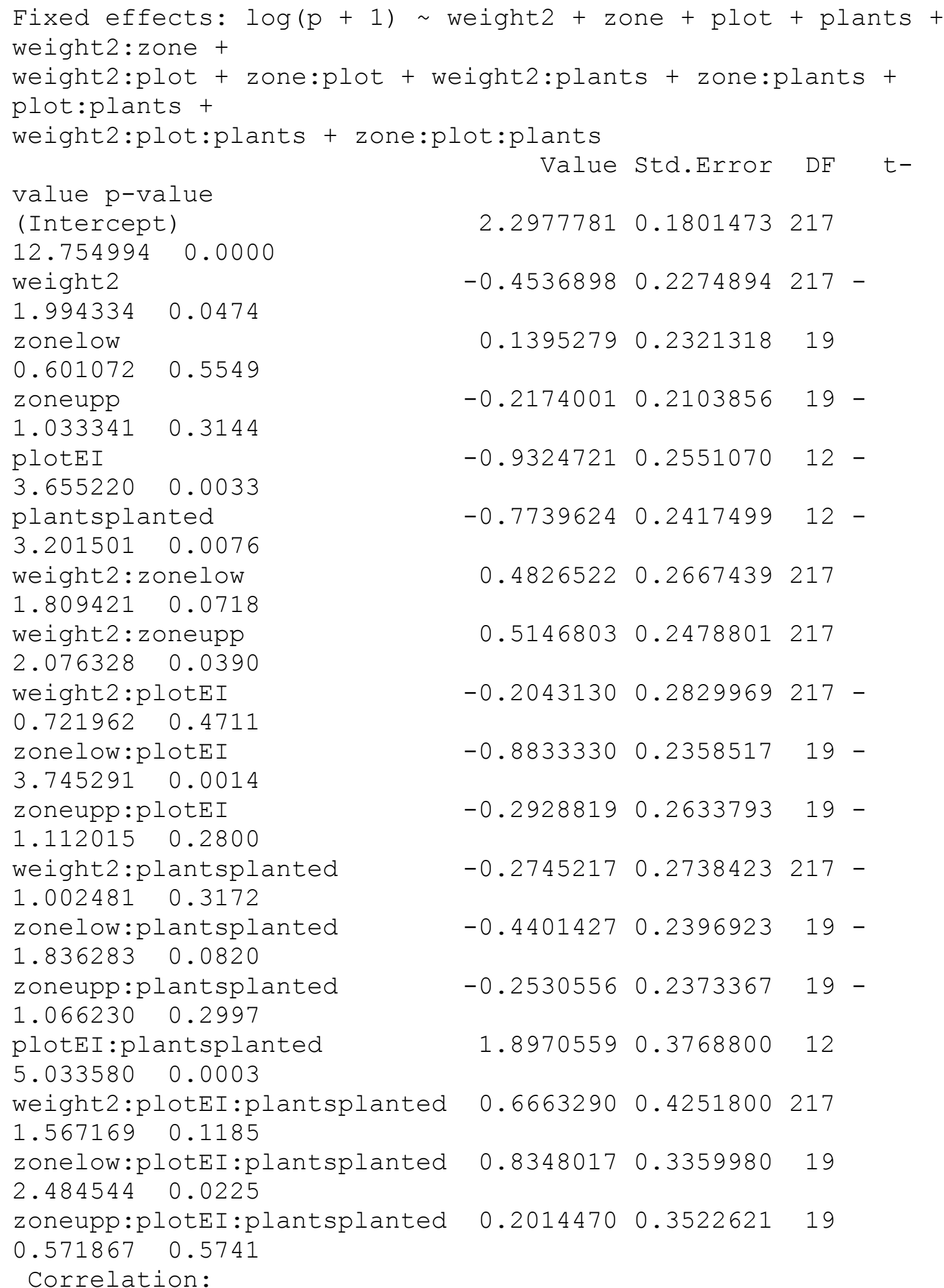


(Intr) weght2 zonelw zonepp

ploteI plntsp wght2:znl wght2:znp wg2:EI znl:EI

weight2

zonelow

zoneupp

ploteI

plantsplanted

0.386

weight 2 : zonelow

$0.061-0.028$

weight 2 : zoneupp

$\begin{array}{lll}0.042 & 0.093 & 0.469\end{array}$

weight2:ploteI

$0.748-0.237 \quad 0.002$

zonelow:ploteI

$0.445-0.231-0.144$

zoneupp:ploteI

$0.489-0.281-0.059$

weight2:plantsplanted

$\begin{array}{lll}0.235 & -0.710 & 0.071\end{array}$

zonelow:plantsplanted

$0.220-0.478-0.041$

zoneupp:plantsplanted

$0.270-0.575-0.021$

ploteI:plantsplanted

$0.660-0.6410 .102$

0.141

$-0.754$

$-0.592$

$-0.734$

0.341

$-0.533$

0.483

$-0.537$

0.303

0.285

0.511

0.181

0.260

0.336

$0.391-0.520-0.711-0.331$

$0.452-0.600-0.320-0.616-$

$0.392-0.521 \quad 0.019-0.164 \quad-$

$\begin{array}{lllll}0.254 & 0.101 & -0.384 & -0.226 & -\end{array}$

$\begin{array}{ll}-0.076 & -0.039\end{array}$

$\begin{array}{lll}-0.154 & 0.089 & 0.455\end{array}$

$-0.090$

$0.341-0.452-0.034-0.034-$

$-0.025$

$0.357-0.027$

$\begin{array}{llllll}0.291 & 0.045 & -0.449 & -0.258 & -\end{array}$

$-0.122$

$\begin{array}{ll}-0.018 & 0.477\end{array}$

$0.348-0.027-0.238-0.474 \quad-$

0.0510 .251

$\begin{array}{lll}0.003 & 0.490 \quad 0.281\end{array}$

$\begin{array}{llllll}0.476 & 0.457 & -0.142 & -0.013 & -0.640 & 0.045\end{array}$

zonelow:ploteI:plantsplanted $-0.200 \quad-0.042 \quad 0.295 \quad 0.183$

$\begin{array}{llllll}0.312 & 0.337 & 0.065 & 0.015 & 0.024 & -0.697\end{array}$

zoneupp:plotEI:plantsplanted $\begin{array}{lllll}-0.243 & 0.029 & 0.169 & 0.329\end{array}$

$0.366 \quad 0.386 \quad 0.002$

0.067

$-0.072-0.334$

pltEI: w2:EI: znl:EI:

znp:EI wght2:p znlw:p znpp:p

weight2

zonelow

zoneupp

ploteI

plantsplanted

weight 2 : zonelow

weight 2 : zoneupp

weight 2 :ploteI

zonelow:ploteI

zoneupp:ploteI

weight 2 :plantsplanted

0.083

zonelow:plantsplanted

$0.222-0.031$

zoneupp:plantsplanted

0.457

0.100

0.506

ploteI:plantsplanted

0.3380 .458

$0.303 \quad 0.364$

weight 2 :ploteI:plantsplanted $-0.075-0.647$

$0.024-0.059-$

0.779

zonelow:ploteI:plantsplanted -0.314

$0.028-0.715-0.359-$

$0.446 \quad 0.007$ 


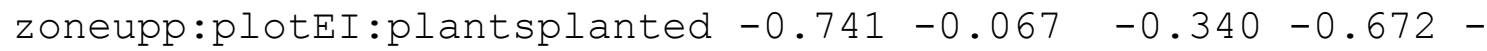
$0.486 \quad 0.0890 .467$

Standardized Within-Group Residuals:

$\begin{array}{rrrrr}\text { Min } & \text { Q1 } & \text { Med } & \text { Q3 } & \text { Max } \\ -2.9736172 & -0.5596307 & -0.1043270 & 0.7226164 & 2.8240792\end{array}$

Number of Observations: 266

Number of Groups:

plotcode zone in\% plotcode

1643

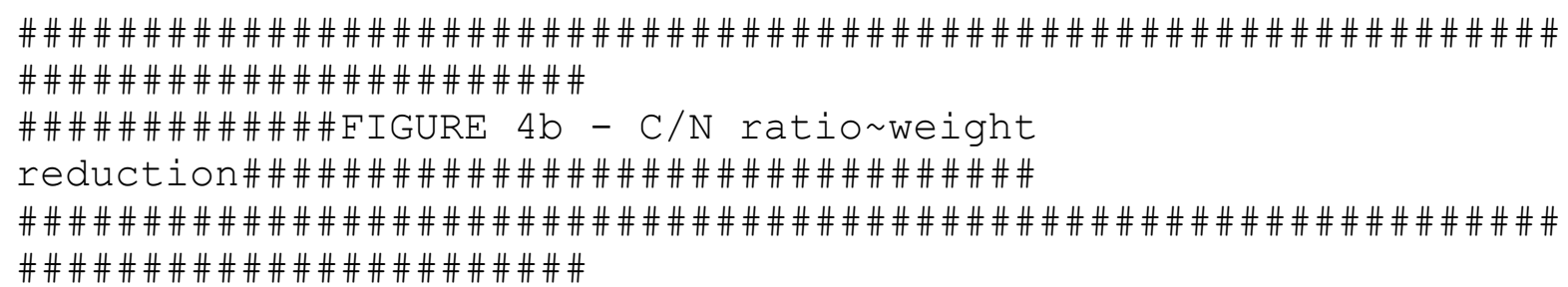

n16 $=$ lme $(\log (\mathrm{c} \cdot \mathrm{n}+1) \sim$ weight $2 *$ zone*plot*plants, random $=\sim 1 \mid$ plotcode / zone, decomp kn, method="ML")

decomp_kn\$zone <- factor (decomp_kn\$zone, levels=c("pio", "low", "upp"))

decomp_kn\$plot <- factor (decomp_kn\$plot, levels=c ("SMC", "EI") )

n17 =stepAIC (n16)

plot (alleffects (n17, transformation=list (link=mylog, inverse=mye xp)),

type="response", ci.style="bands", multiline=T)

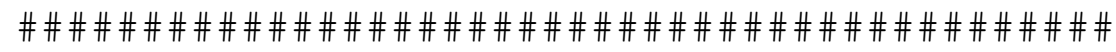

aov (formula $=\mathrm{n} 17$ )

Terms:

weight2 zone plot plants

weight2:zone weight2:plot zone:plot weight2:plants

Sum of Squares $0.621454 \quad 0.152872 \quad 0.494848 \quad 0.093781$
0.106538
$0.186922 \quad 0.105838$
0.129604

Deg. of Freedom

12

2

1

2

21

1

zone:plants plot:plants weight2:zone:plot

weight $2:$ zone:plants weight $2:$ plot:plants
Sum of squares
0.020775
0.125121
2.035283
0.047224
Deg. of Freedom 0.809383
2
1 2

1

Sum of Squares

zone:plot:plants Residuals

Deg. of Freedom

$0.153926 \quad 4.418231$

$2 \quad 362$ 
Residual standard error: 0.1104765

Estimated effects may be unbalanced

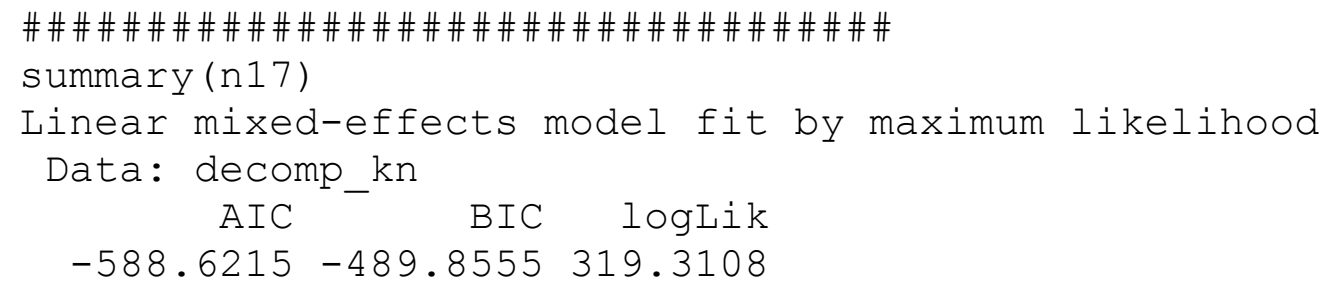

Random effects:

Formula: 1 | plotcode (Intercept)

StdDev: 0.03092523

Formula: 1 | zone \%in\% plotcode (Intercept) Residual

StdDev: 0.016814840 .1017096

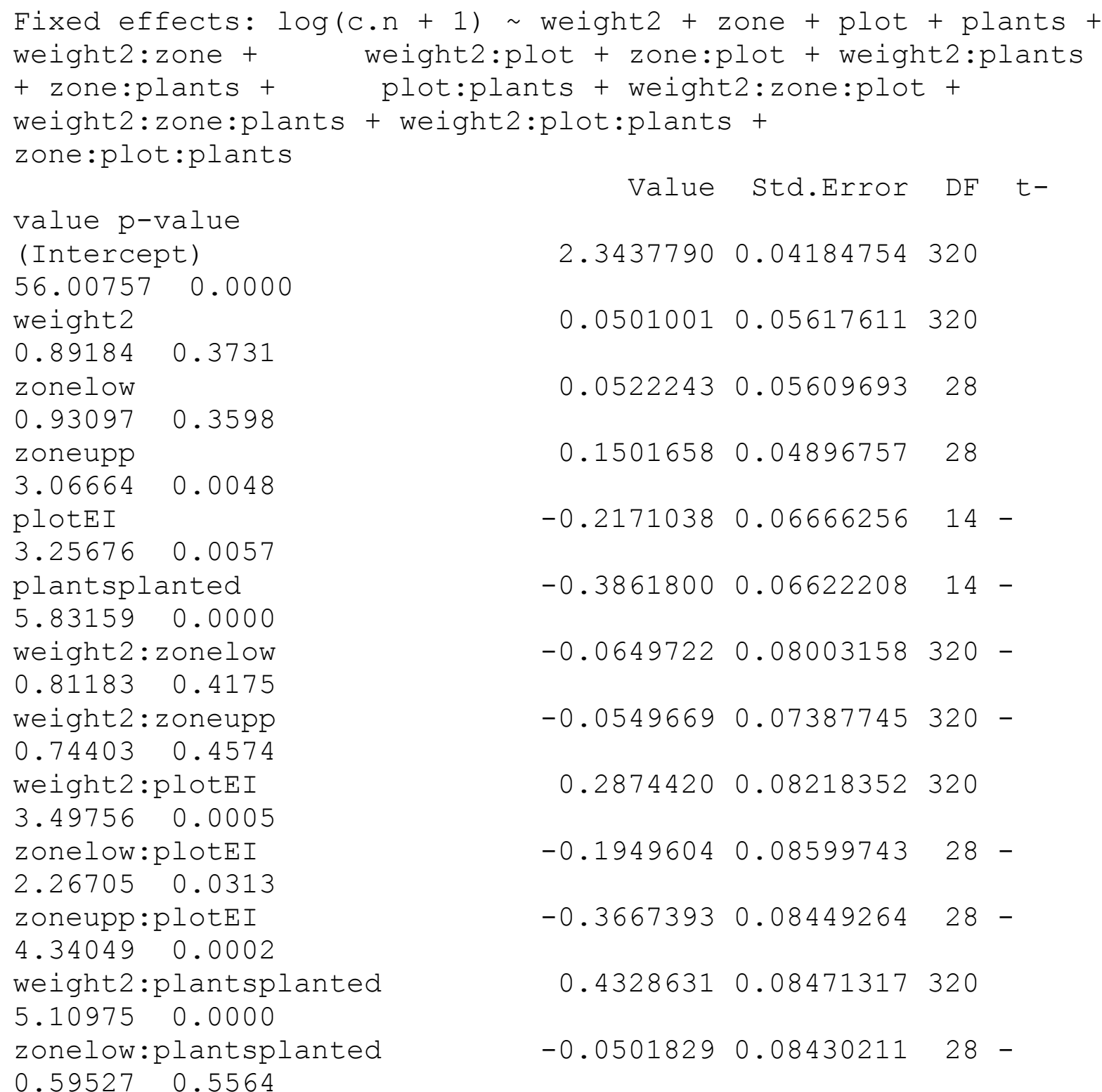




$\begin{array}{lccc}\text { zoneupp:plantsplanted } & 0.0317159 & 0.07401568 & 28 \\ \text { 0.42850 0.6716 } & & & \\ \text { plotEI:plantsplanted } & 0.6586089 & 0.08016225 & 14 \\ \text { 8.21595 0.0000 } & & & \\ \text { weight2:zonelow:ploteI } & 0.1663425 & 0.10745944 & 320 \\ \text { 1.54796 0.1226 } & & & \\ \text { weight2:zoneupp:plotEI } & 0.3023747 & 0.10240201 & 320 \\ \text { 2.95282 0.0034 } & & & \\ \text { weight2:zonelow:plantsplanted } & -0.0881805 & 0.10901344 & 320 \\ \text { 0.80890 0.4192 } & & & \\ \text { weight2:zoneupp:plantsplanted } & -0.2312942 & 0.09990677 & 320 \\ \text { 2.31510 0.0212 } & & & \\ \text { weight2:plotEI:plantsplanted } & -0.6745371 & 0.08623240 & 320 \\ \text { 7.82232 0.0000 } & & & \\ \text { zonelow:plotEI:plantsplanted } & 0.2015914 & 0.05823089 & 28 \\ \text { 3.46193 0.0017 } & & & \\ \text { zoneupp:plotEI:plantsplanted } & 0.1475378 & 0.06235314 & 28 \\ \text { 2.36616 } 0.0251 & & & \end{array}$

(Intr) weght2 zonelw zonepp

ploteI plntsp wght2:znl wght2: znp wg2:EI znl:EI

weight2

zonelow

zoneupp

ploteI

plantsplanted

0.167

weight 2 : zonelow

$0.212-0.201$

weight 2 : zoneupp

$0.234-0.2210 .505$

weight 2 :ploteI

$0.831-0.067 \quad 0.325$

zonelow:ploteI

$0.586 \quad 0.022 \quad 0.352$

zoneupp:ploteI

$\begin{array}{lll}0.566 & 0.056 & 0.177\end{array}$

weight 2 :plantsplanted

$0.053-0.827 \quad 0.292$

zonelow:plantsplanted

$\begin{array}{lll}0.043 & -0.551 & 0.298\end{array}$

zoneupp:plantsplanted

$0.036-0.723 \quad 0.184$

ploteI:plantsplanted

$0.469-0.450-0.088$

weight 2 : zonelow:ploteI

$0.514-0.067-0.528$

weight2: zoneupp:ploteI

$0.501-0.115-0.272 \quad-0.458$

weight 2 : zonelow:plantsplanted

$\begin{array}{llll}0.104 & 0.482 & -0.437 & -0.256\end{array}$

0.357

0.185

0.320

0.180

0.353
$-0.785$

$-0.610 \quad 0.551$

$\begin{array}{ll}-0.708 & 0.642\end{array}$

$\begin{array}{llll}-0.543 & 0.385 & 0.286 & 0.346\end{array}$

$\begin{array}{lllll}-0.537 & 0.375 & 0.277 & 0.336\end{array}$

$0.520-0.662-0.857-0.445-$

$0.564-0.718-0.422-0.794-$

$0.442-0.563-0.268-0.329-$

$0.296-0.230-0.475-0.260-$

$$
0.514
$$

$0.286-0.214-0.237-0.388-$

$\begin{array}{lll}0.216 & 0.488 & 0.487\end{array}$

$\begin{array}{llllll}0.411 & -0.524 & -0.240 & -0.298 & -\end{array}$

$0.129-0.088$

$0.280-0.206-0.432-0.255$

$-0.103-0.133$

$\begin{array}{lllll}0.364 & -0.292 & -0.253 & -0.524 & -\end{array}$ $-0.015-0.007$

$0.256-0.071-0.014-0.060-$ $0.254 \quad 0.054$

$\begin{array}{llll}-0.278 & 0.354 & 0.452 & 0.242\end{array}$ $-0.621-0.871$

$\begin{array}{llll}-0.271 & 0.345 & 0.228 & 0.366\end{array}$ $-0.605-0.442$

$\begin{array}{llllll}-0.241 & 0.307 & 0.374 & 0.222 & -\end{array}$ $0.074 \quad 0.233$ 
weight 2 : zoneupp:plantsplanted $\begin{array}{lllll}-0.300 & 0.383 & 0.211 & 0.432 & -\end{array}$

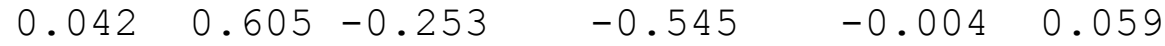

weight2:ploteI:plantsplanted $\begin{array}{llll}-0.172 & 0.219 & -0.030 & 0.023\end{array}$ $\begin{array}{llllll}0.331 & 0.347 & 0.027 & 0.014 & -0.396 & 0.061\end{array}$

zonelow:ploteI:plantsplanted $\quad \begin{array}{lllll}-0.067 & -0.133 & 0.105 & 0.058\end{array}$

$\begin{array}{llllll}0.180 & 0.122 & 0.177 & 0.100 & 0.068 & -0.326\end{array}$

zoneupp:plotEI:plantsplanted $\quad \begin{array}{lllll}-0.072 & -0.112 & 0.046 & 0.105\end{array}$

$\begin{array}{llllll}0.183 & 0.132 & 0.088 & 0.233 & 0.045 & -0.127\end{array}$

znp:EI wght2:p znlw:p znpp:p

pltEI: wght2:znl:EI wght2:znp:EI wght2:znl:

weight2

zonelow

zoneupp

ploteI

plantsplanted

weight 2 : zonelow

weight 2 : zoneupp

weight 2 :ploteI

zonelow:ploteI

zoneupp:ploteI

weight 2 :plantsplanted

$-0.130$

zonelow:plantsplanted

$0.020 \quad 0.476$

zoneupp:plantsplanted

$\begin{array}{ll}-0.054 & 0.657\end{array}$

$\begin{array}{llll}-0.015 & 0.228 & -0.031 & 0.170\end{array}$

ploteI:plantsplanted

$-0.427$

0.045

$0.213 \quad 0.051$

0.076

weight 2 : zoneupp:ploteI

$\begin{array}{llll}-0.831 & 0.100 & 0.020 & 0.132\end{array}$

$0.170 \quad 0.522$

weight 2 : zonelow:plantsplanted

$0.031-0.583-0.867-0.455$

$0.168-0.175 \quad 0.001$

weight 2 : zoneupp:plantsplanted

$0.013-0.026 \quad-0.085$

$\begin{array}{lllll}0.192 & -0.731 & -0.440 & -0.814\end{array}$

0.529

weight $2:$ ploteI:plantsplanted

$0.764-0.050 \quad-0.170$

$0.153-0.420 \quad 0.132-0.117$ -

zonelow:ploteI:plantsplanted $-0.126$

$\begin{array}{ll}0.378-0.036 & -0.055 \\ \text { zoneupp:ploteI:plantsplanted }\end{array}$

$\begin{array}{lllll}-0.141 & 0.128 & -0.239 & -0.110 & -\end{array}$ $-0.139$

$\begin{array}{lllll}-0.405 & 0.098 & -0.083 & -0.212 & -\end{array}$ $-0.099$

$0.390-0.051 \quad-0.018$

wght2:znp: w2:EI: znl:EI:

weight2

zonelow

zoneupp

ploteI

plantsplanted

weight2: zonelow

weight 2 : zoneupp

weight 2 :ploteI

zonelow:ploteI

zoneupp:ploteI

weight 2 :plantsplanted

zonelow:plantsplanted

zoneupp:plantsplanted 
ploteI:plantsplanted

weight 2 : zonelow:ploteI

weight 2 : zoneupp:ploteI

weight 2 : zonelow:plantsplanted

weight 2 : zoneupp:plantsplanted

weight 2 :plotEI:plantsplanted

zonelow: plotEI:plantsplanted

zoneupp:plotEI:plantsplanted

0.086
-0.108
-0.230

0.001

$0.050 \quad 0.484$

Standardized Within-Group Residuals:

Min Q1 Med Q3

$\operatorname{Max}$

$\begin{array}{lllll}-3.153602697 & -0.426128094 & 0.004212692 & 0.510560268\end{array}$

4.210988835

Number of Observations: 384

Number of Groups:

plotcode zone oin\% plotcode

18

54

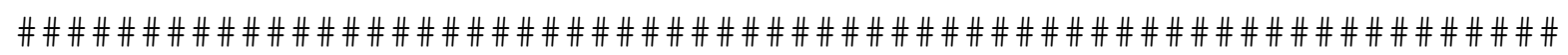

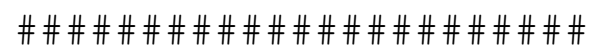

\#\#\#\#\#\#\#\#\#\#\#\#IGURE 5 - linkage species richness ecosystem

functioning, C/N ratio\#\#\#\#

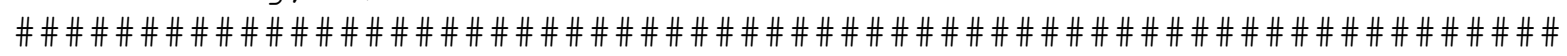

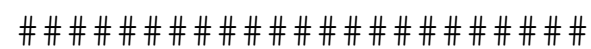

done with flylarvae (=abundance of maggots), species richness (of maggots)

and abundance of Hydden, scaste und spelut

\#\#\#flylarvae:\#\#\#

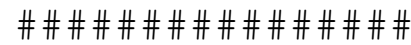

cn.modl=lme $\left(\mathrm{c} . \mathrm{n} \sim(\log . \mathrm{flylarvae}+\mathrm{zone}+\mathrm{plot}+\mathrm{loc})^{\wedge} 3\right.$, random= $1 \mid \mathrm{plot}$ code/zone/loc, data=decomp2.3)

cn. modla=update ( $\mathrm{cn}$. mod1, correlation=corARl ( form= day))

summary (cn.modla) \#\#Modell in Korrelationsstufe 1.Ordnung, für

day | plotcode/zone/loc

plot (ranef (cn.mod1)) \#\#Residuen in kleinem range, sehen gut aus

cn. $\bmod 1 \mathrm{~b}=$ update ( $\mathrm{cn} . \bmod 1 \mathrm{a}, \operatorname{method="ML")}$

$\mathrm{cn} \cdot \bmod 2=$ stepAIC $(\mathrm{cn} \cdot \bmod 1 \mathrm{~b})$

plot (alleffects (cn.mod2,

multiline=T,ci.style="bands", type="response",ylab="C:N

ratio"))

\#\#\#species richness:\#\#\#

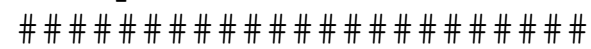




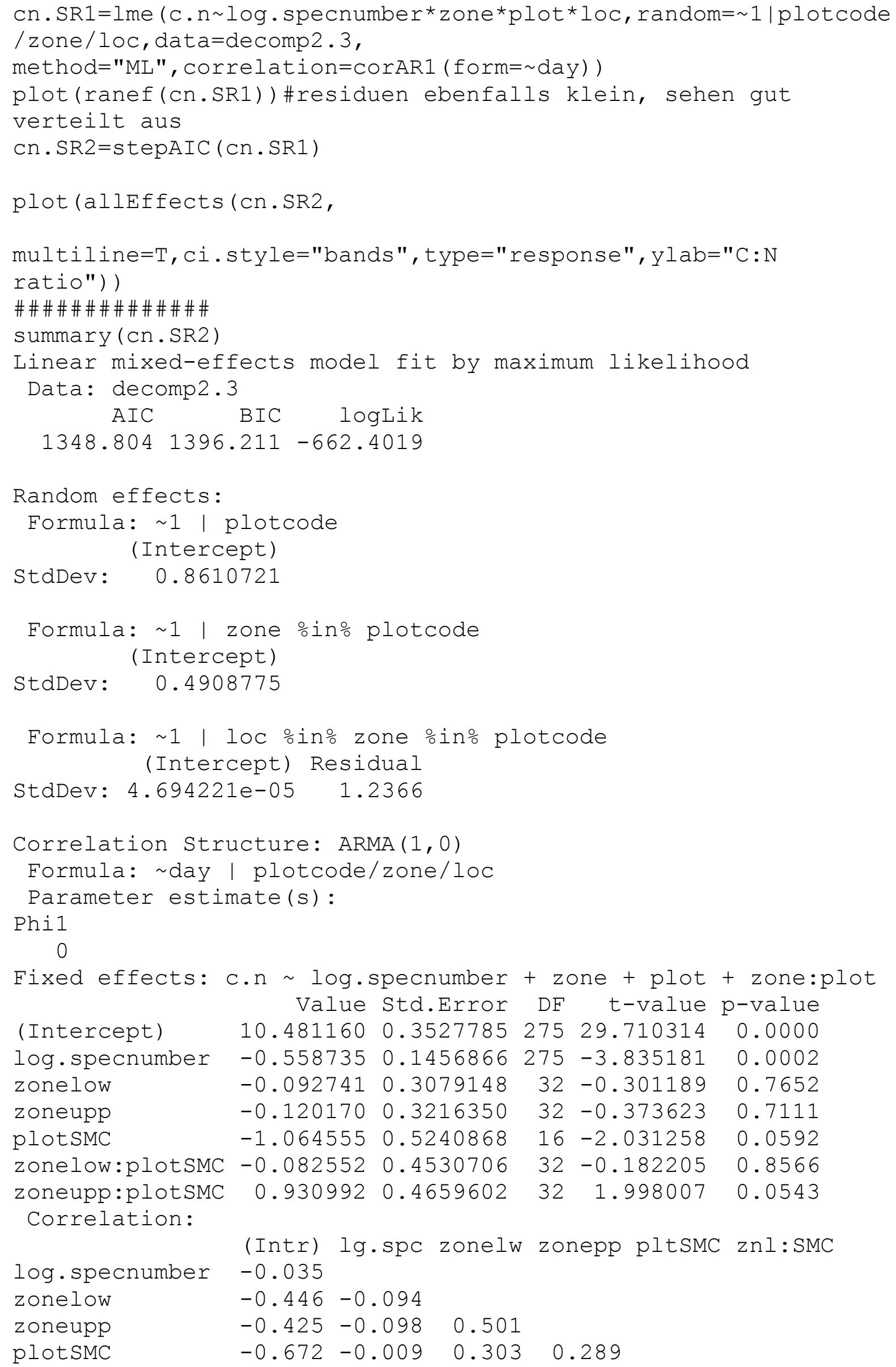


zonelow:plotSMC

$0.307-0.041-0.670-0.330-0.441$

zoneupp:plotsMC

$0.299-0.091-0.331-0.675-0.427$

0.499

Standardized Within-Group Residuals:

Min 01 Med

Q3 $\quad$ Max

$\begin{array}{llllll}-2.80106569 & -0.48778568 & -0.01769793 & 0.50489472 & 3.95021253\end{array}$

Number of Observations: 384

Number of Groups:

in zone in\% plotcode

$$
\text { plotcode zone \%in\% plotcode loc }
$$

54

108

\#\#\#abundance of Hydden, Scaste und spelut\#\#\#

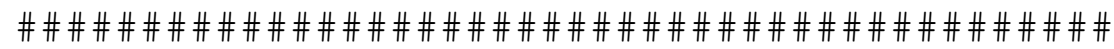

$\mathrm{cn} . \mathrm{SP} 1=\operatorname{lme}(\mathrm{c} \cdot \mathrm{n} \sim((\log \cdot \mathrm{Scaste}+\log \cdot$ Hydden+log. Spelut $)+$ zone+plot+l oc) $\wedge 2$,

random= 1 | plotcode/zone/loc, data=decomp2.3, method="ML", correla

tion=corAR1 ( form $=\sim$ day) )

$\mathrm{cn} . \mathrm{SP} 2=$ stepAIC $(\mathrm{cn} \cdot \mathrm{SP} 1)$

plot (alleffects (cn.SP2,

multiline=T,ci.style="bands", type="response",ylab="C:N

ratio"))

\#\#\#\#\#

\#\#\#\#\#

$\operatorname{AICC}(\mathrm{cn} . \bmod 2) \quad[1] \quad 1351.092$

$\operatorname{AICC}(\mathrm{cn} . \mathrm{SR} 2) \quad[1] \quad 1349.645$

$\operatorname{AICC}(\mathrm{Cn} . \mathrm{SP} 1) \quad[1] \quad 1388.974$

\#\#\#\#\#

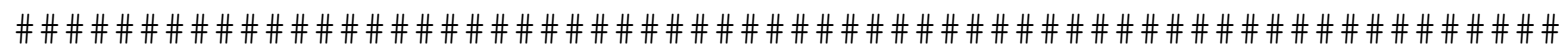
\#\#\#\#\#

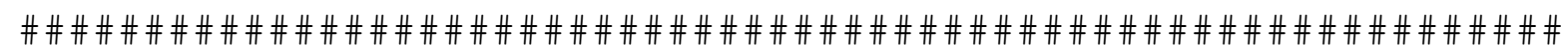
\#\#\#\#\#

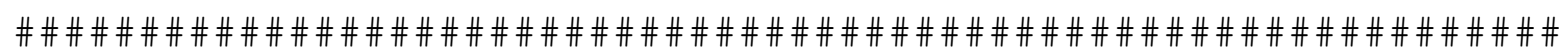
\#\# \#\# \# 


\section{THESIS SUMMARY}

The field of island research is one of the best researched topics in ecological and evolutionary research. As islands are spatially restricted and basic principles of island colonization are investigated, they display one of the best research patches to be based on. Islands are classified into oceanic islands, continental shelf islands, habitat islands or non-marine islands. Within the last decades, most studies focused on oceanic islands as they are good research models for habitats, which started to establish millions of years ago. In the context of global warming and rising sea levels, islands have also attracted public attention due to more frequent inundation and tsunami events in the last couple of years.

Barrier islands are mostly located in the offshore region of mainland region with access to the open sea. As they are not too much isolated from mainland region, they are more or less densely populated. They are only built by offshore sedimentation processes. On the coastal line from the Netherlands op to southern Denmark, the East Frisian Islands belong to this worldwide distributed island type. Heavy thunderstorms and storm tide tremendously affect island maintenance and formation. Therefore, about 40 years ago, humans started to save these islands by constructing dykes and bulwarks to reduce wave energy and safe dunes from strong erosion processes.

Our research area Spiekeroog belongs to the East Frisian Islands and is one of the larger islands of this barrier island chain in front of the German North Sea coastline.

To generate knowledge, how barrier islands establish in the North Sea area, together with the University of Oldenburg, we constructed 12 experimental islands along the southern part of Spiekeroog to observe initial colonization processes of arthropods onto our artificial islands. We constructed six planted (filled with Wadden Sea sediment and Lower Salt Marsh sods) and six non-planted (Wadden Sea sediment filled only) experimental islands and related control plots in the salt marsh habitat of Spiekeroog.

Our research aim was to (I) analyze general island specific characteristics (such as sedimentation and erosion rates) of all East Frisian Islands as main variables which influence colonization processes by different taxa, (II) observe the abundance and probability of taxon occurrence of different arthropod taxa colonizing our experimental islands and combine them regarding our experimental treatment and to (III) focus on animal decomposition in salt marsh habitats both in control and experimental island 
plots to generate information about ecosystem functions in these highly disturbed habitats.

In the second chapter we analyzed more than 2,990 species across 36 taxon groups (including vertebrates, invertebrates and land plants) on German barrier islands, the East Frisian Islands. We tested for relationships between species richness and island area (SAR), for effects of island habitat heterogeneity ( $\mathrm{SHH}$ ) and further island parameters using binomial logistic regression modelling. The positive impact of annual sedimentation rates of barrier islands on rove beetles and flies illustrate the importance of considering ontogenetic island data in the biodiversity analysis of barrier islands. Four taxa such as spiders (173 species) and lichens ( 94 species) were primarily related to area. The heterogeneity of habitat types was a key predictor for the richness of 24 taxa, including bees (101 species), Auchenorrhyncha (131 species), Saltatoria (13 species) and further 21 taxa, whereas richness differences of 6 taxa could not be explained. Overall, richness of taxa differed greatly in their responses, with area (although varying from 0.1 to $38.9 \mathrm{~km}^{2}$ ) playing a minor and island heterogeneity a major role, while barrier island-specific sedimentation rates emerge as a new predictor variable in models explaining species richness (14 out of 31 taxa in total).

In the third chapter we set up six planted (with salt-marsh vegetation) and six nonplanted experimental islands at a distance of c. $500 \mathrm{~m}$ south of the North Sea island of Spiekeroog (Germany) to study colonization dynamics of mobile arthropods in a standardized way. We sampled c. 40,000 arthropods during one season (MaySeptember) across eight taxa using storm-proof window, funnel and sticky traps, placed on each of the 12 islands and on six natural salt marsh plots of Spiekeroog. Seven of eight taxa (Aphididae, Araneae, Brachycera, Coleoptera, Hymenoptera, Nematocera and Thysanoptera, but not Auchenorrhyncha) had lower abundances on the experimental islands compared with the Spiekeroog control plots, the presumable source area of the arthropods colonizing the experimental islands. Taxon differed in time of maximal colonization (interaction of island abundance with month of sample) in seven of eight taxa (i.e. with the exception of Araneae). In contrast to expectations, colonization of planted vs non-planted islands did not show major differences: In five taxa, the nonplanted islands showed significantly lower abundance than the Spiekeroog control plots, and in four taxa the planted islands. Our results showed that island colonization by these 
mobile arthropod taxa went quickly already in the first season after island establishment, while arthropod groups appeared to discriminate between planted and non-planted islands in contrasting ways.

In the fourth chapter we performed an animal decomposition experiment using an experimental approach on the barrier island Spiekeroog, Germany. 264 pieces of cow meat were spread over 12 experimental islands and six control plots established in late 2014 to observe animal decay in a real-time experiment. Our two weeks experiment displayed the influence of time and experimental treatment (experimental island or control) on carcass biomass loss, whereas the habitat zonation on each of the 18 plots (pioneer zone, lower salt marsh and upper salt marsh) did not contribute to the explanation. Animal extraction from the carcass (a piece of cow meat) and the soil beneath the carcass highlighted maggots as the taxon with highest abundances, with Scatophaga stercoraria $(\mathrm{n}=670)$, Hydrotaea dentipes $(\mathrm{n}=590)$ and Spelobia luteilabris $(\mathrm{n}=235)$ playing a major role. Maggot community composition changed between marine pioneer zone up to terrestrial upper salt marsh zone. In pioneer zone plots, we recorded three maggot species, whereas in upper salt marshes, we found ten species. Interestingly, higher species richness of maggots was related to higher nutrient release during decomposition, resulting in a lower ratio of carbon and nitrogen in the soil under the carcass.

Overall, we argue, that our barrier island system extend general rules and patterns of classical Island Biogeography and underlines the speciality of a highly disturbed island system, which is daily influenced by tides, wind and sedimentation processes. Our studies provide first evidence that experimentally simulated successional state (planted and non-planted experimental islands vs. transplanted salt marsh control plots) influences arthropod communities much more than habitat zone identity (pioneer zone, lower salt marsh, upper salt marsh). 


\section{ZUSAMMENFASSUNG}

Der Bereich der Inselforschung ist eines der am besten bearbeiteten Felder in Ökologie und Evolutionsforschung. Da Inseln räumlich eingeschränkt und die grundlegenden Prinzipien der Inselbesiedlung erforscht worden sind, stellen sie einen Bereich dar, auf dem man mannigfaltig aufbauen kann. Inseln werden in Ozeanische Inseln, Felslandinseln, Habitatinseln oder nicht-marine Inseln unterteilt. Innerhalb der vergangenen Jahrzehnte haben sich die meisten Publikationen auf Ozeanische Inseln beschränkt, weil diese gute Forschungsmodelle für Habitate darstellen, die sich bereits vor Millionen von Jahren gebildet haben. Im Kontext des globalen Klimawandels und des steigenden Meeresspiegels haben Inseln das öffentliche Interesse vor allem aufgrund häufigerer Überflutungs- und Tsunamiereignisse in den vergangenen Jahren erhalten.

Düneninseln befinden sich oftmals in küstennahen Region des Festlandes mit Zugang zum offenen Meer. Da sie nicht zu stark vom Festland isoliert sind, sind sie relativ stark besiedelt. Sie werden allein durch küstennahe Sedimentationsprozesse gebildet. Entlang der Küstenlinie der Niederlande bis hin nach Süd-Dänemark erstrecken sich die Ostfriesischen Inseln, die zu jenem weltweit verbreiteten Inseltypen zählen. Starke Unwetter und Sturmfluten beeinträchtigen den Inselerhalt und die Inselbildung dramatisch. Aus diesem Grund wurde vor 40 Jahren damit begonnen, diese Inseln durch die Errichtung von Deichen und Bollwerken, mit deren Hilfe die Wellenenergie herabgesetzt wird, und die Dünen vor starken Erosionsprozessen zu schützen.

Die Region unserer Forschungen Spiekeroog gehört zu den Ostfriesischen Inseln und ist eine der größeren Inseln dieses Düneninselbandes vor der Deutschen Nordseeküste.

Um herauszufinden, wie sich Düneninseln in der Nordseeregion etablieren, haben wir gemeinsam mit der Universität Oldenburg 12 experimentelle Inseln entlang des südlichen Teils der Insel Spiekeroog errichtet, um die initialen Kolonisationsprozesse von Arthropoden auf unsere künstlichen Inseln zu erforschen. Wir bauten sechs bepflanzte (gefüllt durch Wattenmeersediment und Soden Unterer Salzwiesenvegetation) und sechs unbepflanzte (allein mit Wattenmeersediment gefüllt) experimentelle Inseln und zugehörige Kontrollflächen in den Salzwiesenhabitaten von Spiekeroog.

Ziel unserer Forschung war es (1) generelle inselspezifische Charakteristika (wie Sedimentations- und Erosionsraten) aller Ostfriesischen Inseln als Hauptvariablen 
dahingehend $\mathrm{zu}$ analysieren, wie sie Kolonisationsprozesse unterschiedlicher Taxa beeinflussen, (II) die Abundanz und Wahrscheinlichkeit des Vorkommens von unterschiedlichen Arthropodentaxa zu betrachten, die unsere experimentellen Inseln besiedeln und diese bezüglich der experimentellen Behandlung zu verbinden und (III) einen Fokus auf tierischen Zersetzung in Salzwiesenhabitaten sowohl auf Kontroll- als auch experimentellen Inselflächen $\mathrm{zu}$ legen, um Informationen über Ökosystemfunktionen dieses hochgradig gestörten Systemes zu erhalten.

In Kapitel 2 analysierten wir mehr als 2990 Arten innerhalb von 36 taxonomischen Gruppen (inklusive Wirbeltiere, Wirbellose und Landpflanzen) der deutschen Düneninseln - den Ostfriesischen Inseln. Wir testeten die Beziehung zwischen Artenreichtum und Inselgröße (SAR) auf Effekte der Habitatheterogenität (SHH) and weiterer Inselparameter mittels binomialer logistischer Regressionsmodellierung. Der positive Einfluss der jährlichen Sedimentationsrate der Düneninsel auf Kurzflügelkäfer und Fliegen stellt die Wichtigkeit angesichts ontogenetischer Inseldaten der der Analyse der Biodiversität von Düneninseln dar. Vier Taxa, darunter Webspinnen (173 Arten) und Flechten (94 Arten) wurden hauptsächlich durch die Inselfläche beeinflusst. Habitatheterogenität war ein Schlüsselanzeichen für die Vielfalt von 24 Taxa, darin enthalten Wildbienen (101 Arten), Zikaden (131 Arten), Grashüpfer (13 Arten) und weitere 21 Taxa, wobei die Vielfalt von sechs Taxa insgesamt nicht erklärt werden konnte. Insgesamt unterschieden sich die Vielfalten der Taxa stark in ihrer Resonanz. Fläche (obwohl sie von 0,1 bis $38,9 \mathrm{~km}^{2}$ variierte) spielte eine untergeordnete Rolle und Inselheterogenität eine übergeordnete Rolle, während sich Düneninsel spezifische Sedimentationsraten als ein neue vorhersagende Variable für Artenvielfalt erklärende Modelle entpuppte (14 von insgesamt 31 Taxa).

In Kapitel 3 errichteten wir sechs bepflanzte (mit Salzwiesenvegetation) und sechs unbepflanzte experimentelle Inseln in Abstand von circa $500 \mathrm{~m}$ südlich gelegen der Nordseeinsel Spiekeroog, um die Kolonisationsdynamik mobiler Arthropoden nach standardisierter Herangehensweise zu analysieren. Wir sammelten um die 40000 Arthropoden innerhalb einer Feldsaision (Mai - September) aus acht Taxa mittels sturmgeprüfter Fenster-, Trichter- und Klebefallen. Diese befanden sich auf zwölf Inseln und auf sechs natürlichen Salzwiesenflächen Spiekeroogs. Sieben der acht Taxa 
(Blattläuse, Webspinnen, Fliegen, Käfer, Hautflügler, Mücken und Fransenflügler, jedoch keine Zikaden) zeigten niedrigere Abundanzen auf den experimentellen Inseln im Vergleich zu den Kontrollflächen auf Spiekeroog selbst auf. Spiekeroog war vermutlich die Quelle der Arten, die die experimentellen Inseln besiedelten. Taxa unterschieden sich in ihrer Zeit maximaler Kolonisationsstärke (Interkation von Inselabundanz und Probenmonat) in sieben von acht Taxa (z.B. mit Ausnahme der Webspinnen). Entgegen der Erwartungen, gab es in der Besiedlung von bepflanzten und unbepflanzten Inseln keine maßgeblichen Unterschiede: In fünf Taxa zeigten die unbepflanzten Inseln eine signifikant niedrigere Abundanz an Arthropoden im Vergleich zu den Kontrollflächen auf Spiekeroog. In vier Taxa war dies bei bepflanzten Inseln der Fall. Unsere Ergebnisse zeigen auf, dass die Inselkolonisation durch diese Arthropoden bereits in der ersten Feldsaision nach der Etablierung des Inselsystems rasch verlief, wobei Arthropodengruppen den Anschein erwecken, zwischen bepflanzten und unbepflanzten Inseln in gegensätzlicher Art und Weise zu unterscheiden.

In Kapitel 4 führten wir ein Experiment zur tierischen Dekomposition unter Zuhilfenahme eines experimentellen Ansatzes auf Spiekeroog durch. 264 Rindfleischstücke wurden auf in der letzten Hälfte des Jahres 2014 etablierten 12 experimentelle Inseln und sechs Kontrollflächen in einem Echtzeit-Experiment ausgebracht. Der zweiwöchige Versuch stellte den Einfluss zwischen Zeit und experimenteller Behandlung (experimentelle Insel oder Kontrollfläche) bezüglich des Biomasseverlustes des Kadavers her, wohingegen Habitatzonierung auf allen 18 Flächen (Pionierzone, Untere Salzwiese, Obere Salzwiese) nicht zu der Erklärung beitrug. Tieraustreibungen des Kadavers und des unter dem Kadaver befindlichen Bodens hoben Maden als Taxon mit der höchsten Abundanz hervor, wobei Scatophaga stercoraria $(\mathrm{n}=670)$, Hydrotaea dentipes $(\mathrm{n}=590)$ und Spelobia luteilbaris $(\mathrm{n}=235)$ die Hauptarten darstellten. Die Zusammensetzung der Madengemeinschaft änderte sich zwischen der marin beeinflussten Pionierzone bis hin zur terrestrisch geprägten Oberen Salzwiese. In der Pionierzone konnten wir drei Arten nachweisen, wohingegen in der Oberen Salzwiese zehn Arten anzutreffen waren. Interessanterweise befand sich die gesteigerte Artenvielfalt der Maden in Beziehung zu höheren Nährstofffreisetzung während des Dekompositionsprozesses, was zu einem verminderten Verhältnis von Kohlenstoff zu Stickstoff im Boden unter dem Kadaver führte. 
Insgesamt bringen wir hervor, dass unser Düneninselsystem die generellen Gesetzmäßigkeiten und Muster der klassischen Inselbiogeographie erweitert und die Spezialität eines hochgradig gestörten Systems untermalt, welches täglich durch den Tidenhub, Wind und Sedimentationsprozese beeinflusst wird. Unsere Untersuchung unterstützt erste Beweise, dass ein experimentell simulierter Sukzessionsstatus (bepflanzte und nicht-bepflanzte experimentelle Inseln vs. transplantierter Salziwiesenkontrollflächen) Arthropodengemeinschaften weitaus mehr beeinflusst als die Identität der Habitatzone (Pionierzone, Untere Salzwiese, Obere Salzwiese). 


\title{
PUBLICATIONS AND SCIENTIFIC TALKS
}

\author{
PUBLICATIONS
}

1. Andert, H., Scherber, C., Niedringhaus, R. and Tscharntke, T.: A barrier island perspective on species-area-relationships. Submitted in Journal of Biogeography.

2. Andert, H., Tscharntke, T. and Scherber, C.: Colonization and taxon shift in an experimental island system. In prep (to be submitted in Insect Science).

3. Andert, H., Dinter, T., Scherber, C., Piskurek, O., Scheu, S., Kuzyakov, Y. and Tscharntke, T.: Diversity of decomposing flies and carcass decay in experimental salt-marsh islands of the North Sea, Germany. In prep (to be submitted in Proceedings of the Royal Society B: Biological Sciences).

4. Andert, H. (2010): Hymenoptera-type material of Philipp Adolph Schenck in the Natural History Collection of the Museum Wiesbaden, bembix 30, p. 2-11.

\section{CONFERENCE CONTRIBUTIONS AND SCIENTIFIC TALKS}

- Andert H., Scherber C., Tscharntke T. and Niedringhaus R., 'Revisiting speciesarea-relationships - the case of German barrier islands', Conference of the Ecological Society of America, Faut Lauderdale (USA), 9th of August, 2016 (oral presentation)

- Andert H., Scherber C. and Tscharntke T., 'Revisiting species-area-relationships the case of German barrier islands', II. International Conference on Island Evolution, Ecology and Conservation (Island Biology), Terceira (Portugal), 20 ${ }^{\text {th }}$ of July, 2016 (oral presentation)

- Andert H., 'Decomposition of carcass along a marine-terrestrial gradient in the Northern Sea (Germany)', Forensic Entomology Seminar, Göttingen (Germany), $23^{\text {rd }}$ of June, 2016 (invited oral presentation)

- Andert H., 'BEFmate - Biodiversität und Ökosystemfunktionen von marinen hinüber zu terrestrischen Ökosystemen'(German), Conference of the Working group Diptera, Kelbra (Germany), 17th of June, 2016 (oral presentation)

- Andert H., 'To colonize or not to colonize - colonization of a resort', Ecological Seminar, Göttingen (Germany), 16 ${ }^{\text {th }}$ of December, 2015 (oral presentation)

- Andert H., 'Live and Let Die', Ecological Seminar, Göttingen (Germany), $10^{\text {th }}$ of June, 2015 (oral presentation) 
- Andert H., 'Biodiversity - Ecosystem Functioning across marine and terrestrial ecosystems', Ecological Seminar, Göttingen (Germany), 8 ${ }^{\text {th }}$ of October, 2014 (oral presentation)

- Andert H. and Weigelt P., 'The BEFmate Project', BION Alumni Seminar, Göttingen (Germany), 15th of September, 2014 (invited oral presentation)

- Andert H., 'Comparative studies on the surface chemistry of several Nomadaspecies and their hosts - background information for Agroecology', Ecological Seminar, Göttingen (Germany), 28 ${ }^{\text {th }}$ of May, 2014 (oral presentation) 


\section{CURRICULUM VITAE}

$\begin{array}{ll}\text { Name } & \text { Hagen Andert } \\ \text { E-Mail } & \text { hagen.andert@gmx.de }\end{array}$

\section{Research Expertise}

Skills and Qualifications

- Succession- and Disturbance Ecology

- Multivariate Statistics and Modelling, Meta- Analysis

- Insect Taxonomy and Nomenclature

- Data management, PCR, Barcoding

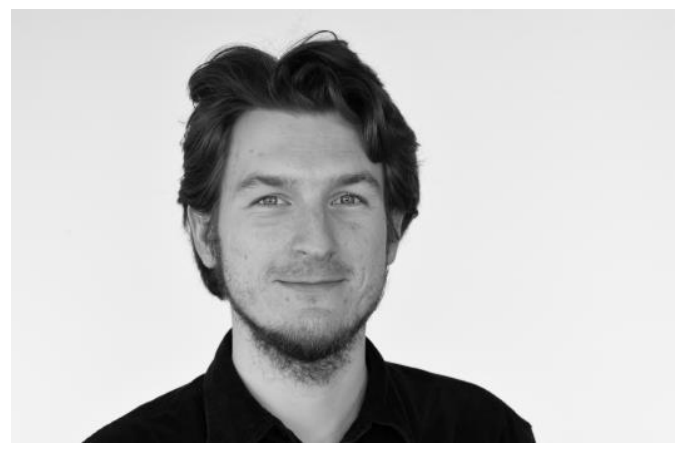

- Team Building, Project Management

- Outstanding Written and Oral Communication

- University Teaching

- Sales and Fundraising

Computing Skills: Microsoft Office, Adobe Photoshop, Statistics software 'R', ArcGIS, GraphPad Prism Languages: English (near-native fluency), German (native fluency), Russian (beginner)

\section{Education}

2017 (expected)

Georg-August-University Göttingen

Dissertation in Agroecology (Island Biogeography)

Biodiversity, ecosystem functioning

Advisors: Prof. Dr. Teja Tscharntke, Prof. Dr. Christoph Scherber

2013

Albert-Ludwigs-University Freiburg

Master of Science in Biology (Neurodevelopmental Biology)

Epilepsy, genetic engineering

Advisors: Prof. Dr. Wolfgang Driever, Prof. Dr. Carola Haas

2011

Albert-Ludwigs-University Freiburg

Bachelor of Science in Biology (Chemical Ecology)

Insect chemistry, gas chromatography

Advisor: Dr. Thomas Schmitt

\section{Research Experiences}

04/2014 - Present

$10 / 2013$

$12 / 2010-$

$07 / 2011$

$8 / 2008$
Scientific Researcher

Georg-August-University Göttingen

Ecology, Island Biogeography, Entomology, multinomial analysis, scientific writing

Scientific Internship

Albert-Ludwigs-University Freiburg

Ecology, RNA isolation, sequencing

Collegiate assistant

Albert-Ludwigs-University Freiburg

Chemical Ecology, GC-MS analysis, Population Ecology

Scientific Internship 
Museum Wiesbaden

Collection management, public relations, taxonomy, scientific writing

\section{Teaching Experiences}

2015 - Present Lecturer, Agroecology group, Department for Crop Sciences, Georg-AugustUniversity Göttingen

- Honeybees and wild bees in agricultural landscapes

- Hymenoptera identification course

- Natural Conservation in agricultural landscapes

$2011-2013$

Teaching Assistant, Evolutionary Biology and Ecology and Developmental Biology, Albert-Ludwigs-University Freiburg

- Performance physiology

- Zoological field trips

- Neuroscience - The Basics

- Anatomy of invertebrates

\section{Awards}

2016

Universitätsbund Göttingen e.V.

Funding for Networking for Junior Researches

\section{Volunteer Work}

$2012-2015$

Organizer, Working group of nature protection (AGN), Freiburg

- Organization and ecosystem services in protected areas

$2009-2010$

Principal of male voices, Biological choir 'Contrappunto bestiale', Albert-LudwigsUniversity Freiburg

- Organization of male rehearsals, conflict management

$2002-2008$

Temporary worker in an Entomological Collection (SMNG Görlitz)

- Collection assistance, identification of European insects

$1998-2008$

Principal Clarinetist, German-Polish Youth Orchestra Görlitz

- Organization of wood brass rehearsals, conflict management, enhancement of group efficiency

\section{Professional Associations}

- German Society of General and Applied Entomology (DGaaE)

- Working Group Diptera (AK Diptera)

- Booster Club of the Natural History Society Stuttgart

- Natural History Society Karlsruhe 


\section{ACKNOWLEDGEMENTS}

Over the last 3.5 years this work was supported by several people, who helped me in different stages of inner and outer thesis preparation. I therefore sincerely thank:

Teja Tschjarntke for his kind, extensive and paternal supervision and his generosity to develop and focus my scientific equipment. Thank you so much for yor openness, honesty and your all-day accessibility!

$>$ Christoph Scherber for his indescribable creativity, his unalterable statistical support, the best statistical hours I have ever had and will have and his great heart!

$>$ Holger Kreft for his spontaneous attendance as third member of my defense commission.

> Thomas Dinter and Regine Redelstein for their all-time scientific and privat support when field work tended to drown myself. I always enjoyed our beautiful hours on Spiekeroog and sometimes Siberian field work conditions.

$>$ Michael Kleyer and Helmut Hillebrand for their precious experience and advices about the BEFmate project and field work specialties of the Wadden Sea.

> All student co-workes, PhD students and PIs of the BEFmate project! "Everything for the islands, everything for the project!"

$>$ The state of Lower Saxony and VW foundation, who gave funds for the BEFmate project.

$>$ The scientific administration team of the 'Nationalpark-Haus Wittbülten', Charlotte Winkelmann and Swaantje Fock.

$>$ Georg Scheiffarth from the National Park administration and Edgar Schonart, who supported our decomposition experiment and made everything possible in the field!

$>$ The administration of the 'Wadden Sea National Park Lower Saxony' together with the Lower Saxony Water Management, Coastal Defence and Nature Conservation Agency (NLWKN), nominal Peter Südbeck, Richard Czeck, Norbert Hecker, Bernd Oltmanns and Heinz-Hermann Kathmann.

> Stefan Scheu and Susanne Boening-Klein, who made soil arthropod extraction possible for me - thank you so much for every minute for your open ears! 
$>$ Oliver Piskurek and Fabian Haß for their magical abilities to get any possible genetic information out of our carcass inhabiting maggots!

My unbeatable student co-workers Lena Knopp and Tim Niclas Hofmann and my students Henrik Asmus Sinjen and Hannes Christoph Schütze, who helped me a lot to get patterns into a mess of thousands of caught arthropods, also during worst weather conditions!

Fuad Nurdiansyah, Annemarie Wurz and Barbara Saintes for a beautiful, fruitful and inspiring office mood and precious comments.

Lydia Betz, Hannah Reininghaus, Julia Tiede and Florian Lauer for warm and fruitful conversations, mental support and the special aside-science feeling.

$>$ Lisa Denmead, who brought my tortuous English into an understandable line.

$>$ All Agroecologists for being the best working group in the world!!!

$>$ My mother, who always taught me to open my mind for everything to make it real!

$>$ The family of my wife, supporting me and my scientific dreams wherever they could.

Last but not least, after hundreds of taped skewers, unpleasant smelling of Wadden Sea mud or decaying meat odor soaked clothes, I thank my beloved wife for all her patience, motivation, criticism and help over the last years. This thesis would not be finished without her... спасибо моя Даша, мой друг, мой товарищ, мое солнышко и мое все! 


\section{THESIS DECLERATIONS}

\section{Decleration of the author's own contribution to manuscripts with multiple authors}

Chapters 2, 3 and 4 are manuscripts prepared for submission to peer-reviewed journals. I am the lead author of manuscripts of chapters 2, 3 and 4. Additionally, Thomas Dinter is an equally contributing author in Chapter 4 in the field of soil nutrient analysis. I personally have contributed to the study design, data collection and statistical analyses for all manuscripts. Especially in Chapter 2, Rolf Niedringhaus provided the original data set with abundances, generated from former mentioned Niedringhaus et al. 2008. I have developed the main ideas presented in the manuscripts, written manuscripts 2,3 and 4, and created all corresponding tables, figures, and appendices. When taken from another author or publication, relating figure is declared so. The co-authors gave advice and contributed to various parts of the study, such as data collection and analyses, discussions and writing. All co-authors contributed to finalizing the manuscripts.

\section{Declaration plagiarism}

I hereby conform that I have written this doctoral thesis independently, that I have not used sources or facilities other than ones mentioned, that I have not used unauthorized assistance, and that I have not submitted this thesis previously in any form for another degree at any university or institution.

Göttingen, 29th September 2017

Hagen Andert 